Letter Report: Evaluation of LFCM OffGas System Technologies for the HWVP

R. W. Goles

J. Mishima

A. J. Schmidt

March 1996

Prepared for

the U.S. Department of Energy

under Contract DE-AC06-76RLO 1830

Pacific Northwest National Laboratory

Richland, Washington 99352 
PNNL-11062

UC-810

Project Technical Information

\title{
Letter Report: Evaluation of LFCM Off-Gas System Technologies for the HWVP
}

\author{
R. W. Goles \\ J. Mishima
}

A. J. Schmidt

March 1996

Prepared for the U.S. Department of Energy. under Contract DE-AC06-76RLO 1830

Pacific Northwest National Laboratory

Richland, Washington 99352 



\title{
DISCLAIMER
}

This report was prepared as an account of work sponsored by an agency of the United States Government. Neither the United States Government nor any agency thereof, nor Battelle Memorial Institute, nor any of their employees, makes any warranty, express or implied, or assumes any legal liability or responsibility for the accuracy, completeness, or.usefulness of any information, apparatus, product, or process disclosed, or represents that its use would not infringe privately owned rights. Reference herein to any specific commercial product, process, or service by trade name, trademark, manufacturer, or othenwise does not necessarily constitute or imply its endorsement, recommendation, or favoring by the United States Government or any agency thereof, or Battelle Memorial Institute. The views and opinions of authors expressed herein do not necessarily state or reflect those of the United States Government or any agency thereof.

\author{
PACIFIC NORTHWEST NATIONAL LABORATORY \\ operated by \\ BATTELLE. \\ for the \\ $\cdot$ \\ UNITED STATES DEPARTMENT OF ENERGY \\ under Contract DE-ACO6-76RLO 1830
}

\author{
Printed in the Uniled States of America \\ Available to DOE and DOE contractors from the \\ Office of Scientific and Tecrinical information, P.O. Box 62, Oak Ridge, TN 37831; \\ prices, available from (615) 576-8401.
}

Available to the pablic from the National Technical Information Service, U.S. Department of Commerce, 5285 Port Royal Rd., Springfield, VA 22161 

The off-gas performance characteristics of the DWPF, HVDP, and HWVP process off-gas (POG) systems have been evaluated under normal and offnormal HWVP processing conditions. The effectiveness of both the melter offgas (MOG) and the corresponding process vessel ventilation (PVV) systems were evaluated on the basịs of their effluent emission abatement performance from which a combined POG emission (stack) source term was established. Each offgas technology was then compared on the basis of these projected stack emissions. Conclusions drawn from these POG performance evaluations are as follows:

- Under normal processing conditions, all three systems will behave similarly and provide nominally equivalent public exposure protection due to the dominating influence of gaseous radionuclide emissions.

- All systems are capable of meeting pub7ic exposure limits at the point of atmospheric injection (the stack) under normal reference processing rates.

- Melter off-gas surging was found to have the greatest effect on the HWVP source term. However, this transient condition was found to affect a11 off-gas technologies equivalently, since they al1 possess similar gaseous effiuent abatement capabilities.

- The DWPF off-gas technology is $20 \mathrm{X}$ more efficient in reducing $\mathrm{plant}$ emissions during melter idling than are the HWVP and WVDP systems. However HWVP and HVDP idiing stack emissions are projected to be only $0.01 \%$ of the normal process release rate.

The affects of MOG system failure upon plant releases were.varied depending upon the off-gas technology modeled.

- DWPF MOG system failure will not influence the plant source term since its MOG back-up system is totally redundant.

- HWVP MOG system faiture is projected to result in a 100-fold decrease in POG aerosol emission abatement capabilities. However, transient plant emissions (dose basis) will increase by only $<1 \%$ during cold cap burn off due to the dominating influence of gaseous radionuclides. Once processing has ceased, stack emissions wi11 remain at $1 \%$ of the normal processing release rate. 
- WVDP MOG systen failure is incompatible with unfiltered HWVP. process cell design as this technology does not provide for an MOG back-up system.

The secondary waste generation characteristics for the alternative offgas system designs have been evaluated. The principle sources of secondary waste examined are solid waste (failed or decommissioned equipment) and liquid waste (process effluent and decontamination solution). The results of the secondary waste evaluation are summarized below.

- The liquid and solid secondary waste generation rates of the HWVP and the WVDP off-gas systems are essentially equivalent.

- The DWPF off-gas system appears to have the potential to generate approximately twice the weight of solid waste and roughiy 7.5 times the liquid waste of the HWVP off-gas system.

The energy required to operate the melter and vessel ventilation off-gas systems for HWVP, DHPF, and. WVDP have been estimated. To provide for a normalized comparison, HWVP melter and vessel vent off-gas source terms were used for all three technologies. The energy analysis is therefore based upon the energy required to process a set quantity and composition of off-gas. The primary conclusions from the energy analysis are stated below:

- The differences in energy consumption and energy costs between the HWVP and the WVDP off-gas systems are insignificant.

- The DWPF off-gas technology is the most energy-comsumptive. The energy costs associated with the operation of the DWPF off-gas technology will be eight times greater than the other two systems.

- The difference in energy requirements between the HWVP and the DWPF systems is primari7y due to the steam required by the DHPF's șteamatomized scrubbers.

- For each off-gas system, the majority of energy costs will be incurred in the treatment of the accumulated liquid effluent. (condensed steam). 


\section{ACRONYMS AND ABBREVIATIONS}

$A C \quad$ alternating current

ACD advanced conceptual design

ACFM actual cubic feet per minute

ANSI American National Standards Institute

BUOGCT back-up off-gas condensate tank

CDC canister decon chamber

CDMC contact decon and maintenance cell

CFMT concentrator feed make-up tank

CFR Code of Federal Regulations .

CHA contact. maintenance area

DCG Derived Concentration Guide

DF decontamination factor

DOE Department of Energy

DWPF Defense Waste Processing Facility

DWTT decon waste treatment tank

EVS ejector venturi scrubber

FAVC formic acid vent condenser

FC film cooter

FCDC final cask decon chamber

HB high bay (melter)

HEME high-efficiency mist eliminator

HEPA high-efficiency particulate air

HLLH high-leve? Tiquid waste

HSS hydro-sonic scrubber

HTO tritiated water

HVAC heating, ventilation, and cooling

HWVP Hanford Waste Vitrification Plant

LFCM liquid-fed ceramic melter

MFHT. melter feed hold tank

MFT melter feed tank

MOG melter off gas

OGC off-gas condenser 
OGCT off-gas condensate tank

PCDC preliminary cask decon chamber

PNL Pacific Northwest Laboratory

POG process off gas

PRBT precipitate reactor bottoms tank

PSCM pilot-scale ceramic melter

PVV process vessel ventilation

RCD . reference conceptual design

RCT - recycle collection tank

RCT recycle collection tank

REDC remote equipment decon celi

REDOX average oxidation state

SAS steam-atomized scrubber

SBS submerged-bed scrubber

SCFM standard cubic feet per minute

SCVC salt cell vent condenser

SFHT spent frit hold tank

SME slurry mix evaporator

SMECT - slurry mix evaporator condensate tank

SRAT slurry receipt and adjustment tank

SRL Savannah River Laboratory

SRP Savannah River Plant

STP standard temperature and pressure

VWS vessel ventilation system

VVSBS vessel vent submerged-bed scrubber

WVDP West Valiey Demonstration Project 


\section{CONTENTS}

SUMMARY

ACRONYMS AND ABBREVIATION .................... . v v

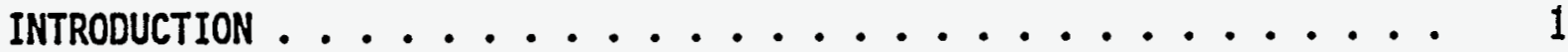

OFF-GAS EFFLUENT EMISSION ABATEMENT PERFORMANCE . . . . . . . . 3

LFCM PROCESS DESCRIPTION .................. 3

LFCM EFFLUENT EMISSION CHARACTERISTICS . . . . . . . . 5

Gaseous Emission ............... 6

Aerosol Emission ................. 14

Melter Emission Performance ............ 16

Emissions During Melter Idling... . . . . . . . 23

LFCM OFF-GAS PROCESSING REQUIREMENTS . . . . . . . . . 28

Primary Scrubbers ............... 33

High-Efficiency Aerosol Scrubbers ............ 45 PROCESS VESSEL VENT SYSTEM . . . . . . . . . . . . 58

BASES FOR PROCESS OFF-GAS SYSTEM EVALUATIONS . . . . . . . 60

Performance Evaluation............... 60

Feed Composition ................. 61

Melter and Off-Gas Performance . . . . . . . . . 62

ASSESSMENT OF POG SYSTEM PERFORMANCE . . . . . . . . . 67

Normal Radioactive Emissions ............. 67

Off-Normal Emissions ............... 69

Conclusion . . . . . . . . . . . . . 74

SECONDARY WASTE GENERATION . . . . . . . . . . . . . . 77

INTRODUCTION ............................... 77

Solid Hastes.................. . . 77 
Liquid Hastes ................... 77

Gaseous Wastes . . . . . . . . . . . 77

EMISSION CONTROL TECHNOLOGIES .............. 78

Relevant HWVP Guidelines ............. 78

Off-Gas Treatment Systems ............. 78

Melter off-Gas System A . . . . . . . . 80

Melter off-Gas System B ............. 8.6

Process Vessel Vent System .............. 89

SECONDARY WASTE GENERATION ..................... 92

OFF-GAS SYSTEMS ENERGY ANALYSIS ............... 101

MASS AND ENERGY BALANCES ................ 104

REFERENCES ......................... 109

APPENDIX A: SIMULANTS AND SUBSTITUTIONS . . . . . . . . A.1

APPENDIX B: ASSUMPTIONS AND BASES FOR ENERGY ANALYSIS . . . . . . B.1 


\section{FIGURES}

1 Liquid-Fed, Joule-Heated Ceramic Melter System . . . . . . . 4

2 Melter Exhaust Gas Composition of a 100-h Boosted, 20 -h Unboosted Test................. 8

3 Compositional Behavior of Noncondensible Melter Exhaust Gases Accompanying a Flow Surge .............. 10

4 Noncondensible Off-Gas Composition Preceding and During Meiter Reboit .................. 11

5 Compositional Behavior of Exhaust Stream Upon Feed Interruption

6 Melter Off-Gas. Compositional Behavior Associated with Feed Termination ............... 13

7 Metter Off-Gas Emission Characteristics .......... 24

8 Cesium Off-Gas Emissions During and After Processing a High Cesium-Bearing Feed

9 Emission Rates of Semivolatile Elements During

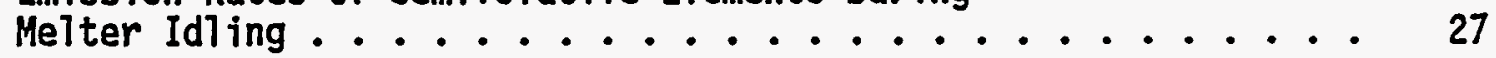

10 DWPF Process 0ff-Gas System .............. 30

11 WVDP Process off-Gas System .................. 31

12 HWVP Process off-Gas System . . . . . . . . . . . 32

13 Principle of Operation of Ejector-Venturi Scrubber from Ametek Brochure .................. 33

14 Principle of Operation of Submerged Bed Scrubber ....... 35

15 Typical Particulate Removal Efficiencies for Type 7014 Ejector Venturi Scrubbers .............. 36

16 Influence of Steam on SBS Performance ........... 37

17 Strontium Concentrations in Melter and SBS Off-Gas Steams

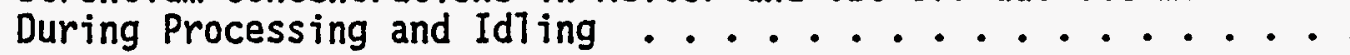

18 Principle of Operation of Hydro-Sonic Scrubber, Adapted from Lone Star Steel Co. Brochure .............

19 Schematic of High-Efficiency Mist Eliminator Used in PNLS PSCM Off-Gas System 
20 Inlet and Outlet Particle Size Distributions Measured

Using Optical and Diffusional Techniques .......... 50

21 Fractional Efficiericy of the Lone Star Steel

Steam-Hydro Scrubber ................... 51

22 Fractional Efficiency Calculated Using Impactor

Data Onty...................... 52

23 Collector Efficiency Comparisons of Various Aerosol

Scrubbers by Particle Size ................. 54

24 Size Distribution of Off-Gas Aerosols as Collected on

Cascade Impactor Stages .................. 56

25 off-Gas film Cooler .......................... 81

26 Submerged-Bed Scrubber . . . . . . . . . . . . 82

27 High-Efficiency Mist Eliminator ............... 83

28 Filter Preheater ........................... 84

29 off-Gas HEPA fitter ........................ 85

$30 \quad$ Steam-Atomized Scrubber ................... 88

31 DWPF High-Efficiency Mi.st Eliminator . . . . . . . . . . 89

32 - DHPF Formic Acid Vent Condenser . . . . . . . . . . . 91

33 DWPF Process Vessel Vent FiTter . . . . . . . . . . 92 


\section{TABLES}

1 Melter DFs for Particulate and Total Feed Component Using Formated Melter Feed .............. 14

2 Size Distribution of Melter Aerosols ............ 15

3 Typical Elemental Distribution Across the Cyclonic

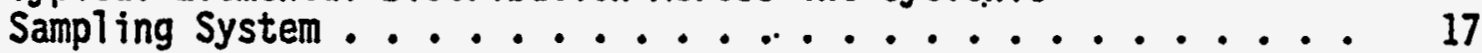

4 Composition of $16-\mu m$ Cyclonic Sample Fraction ......... 18

5 Melter Performance Under Various Processing Conditions ..... 19

6 Steady-State Aerosol Emission Characteristics .......... 20

7 Melter Performance as a Function of Chlorine wt\% ....... 22

8 Aerosol Characteristics Exiting Quench Scrubbers ....... 38

9 Volatile and Nonvolatile Quench Scrubber DFs ......... 38

10 Melter and Quench Scrubber Responses to a Processing Upset ........................ 40

11 Quench Scrubber Response to an Air-Driven Off-Gas Line Film Cooler ................... 41

12 Quench Scrubber Performance as a Function of Scrub Liquor Concentration ............... 43

13 Hydro-Sonic DFs ...................... 53

14 Projected HWVP Radioactive Effluent Releases . . . . . . . 68

15 Projected HWVP Radioactive Effluent Releases ... . . . . . 73

16 Off-Gas Equipment Failure Rate ............. 95

17 Solid Waste Disposal . . . . . . . . . . . . . 96

18 Off-Gas Equipment Decontamination Volumes .......... 98

19 Volume of Liquid Waste Generated by Off-Gas Treatment Systems ..................... 99

20 Off-Gas systems Energy Requirements and Energy Costs . . . . 102

21 Summary of Mass and Energy Balances for Melter off-Gas Systems ................... 105 

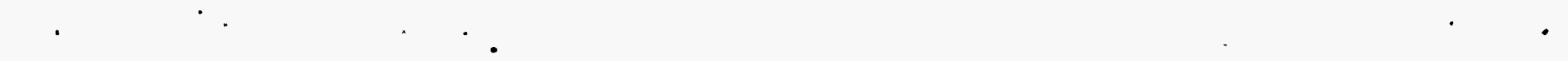


\section{INTRODUCTION}

Radioactive high-level liquid waste (HLLH), a byproduct of defense nuclear fuel reprocessing activities, is currently being stored in underground tanks at several U.S. sites. Because its mobility poses significant environmental risks, HLLW is not a suitable waste form for long-term storage. Thus, high-temperature processes for solidifying and isolating the radioactive components of HLLW have been developed and demonstrated by the U.S. Department of Energy (DOE) and its contractors. Vitrification using liquidfed ceramic melters (LFCMS) is the reference process for converting U.S. HLLW into a borosilicate glass. Two vitrification plants are currently under construction in the United States: the West Valley Demonstration Plant (WVDP) being built at the former Hest Valley Nuclear Fuels Services site in West Valley, New York; and the Defense Waste Processing Facility (DWPF), which is current1y 85\% complete at DOE's Savannah River P1ant (SRP). A third facility, the Hanford Haste Vitrification Plant (HWVP), is being designed at DOE's Hanford Site.

Although all three U.S. vitrification facilities will utilize the same basic vitrification technology, site specific reasons require that plant designs vary somewhat due to local requirements. The off-gas treatment systems used in support of the LFCM process represent one of these design differences. The purpose of this systems analysis report is to compare the performance of vitrification off-gàs technologies with respect to effluent emission abatement, secondary waste generation, and energy consumption as applied to the HWVP p7ant. First, the off-gas emission characteristics of LFCMs will be described from which the functional design bases of off-gas processing requirements will be developed. 'The capabilities and performance of the three off-gas technologies will then be examined in relation to these processing requirements for the HWVP source term. The emission abatement evaluation will then be followed by an analysis of secondary waste generation characteristics and operational energy requirements for these alternative off-gas system designs. 



\section{OFF-GAS EFFLUENT EMISSION ABATEMENT PERFORMANCE}

To properiy evaluate and compare vitrification off-gas system technologies, it is important to understand the nature of the LFCM vitrification process, the characteristics of the effluents generated, the functional capabilities of candidate emission abatement devices, and the bases for evaluating the alternative treatment systems. As a result, these subjects will be thoroughly developed before comparing the effluent abatement capabilities of the HWVP, DHPF, and WVDP off-gas processing systems.

\section{LFCM PROCESS DESCRIPTION.}

Joule-heated, ceramic-7ined melters form the basis of the LFCM process, which is illustrated in Figure 1. This type of glass melter, developed for the commercial glass industry, is composed of a heavily insulated, ceramiclined cavity that contains the molten glass, and corrosion-resistant electrodes. The power required to maintain the glass in its molten state and to process feed chemicals into more glass is supplied by electrical resistive heating produced by passing an electric current (AC) through the glass'pool via the immersed melter electrodes--this is known as Joule heating. Because Joule-heated ceramic melters can attain higher temperatures than conventional melters, high-silica glasses with exceptional chemical stability can be fabricated using this device. This is an important feature in LFCM applications because the vitreous waste form must exhibit low aqueous leaching rates to qualify for long-term geological storage.

Application of joule-heated ceramic melters to the vitrification of HLLW is a straightforward extension of glass-making technology; the waste components are treated merely as a subset of chemicals needed to produce a specified glass product. In the LFCM process, major glass-forming chemicals and/or glass frit are mixed with the HLLW stream to produce an aqueous slurry that is continuously fed to the Joule-heated melter to produce a molten. radioactive glass. The molten melter glass product, which commonly has a 


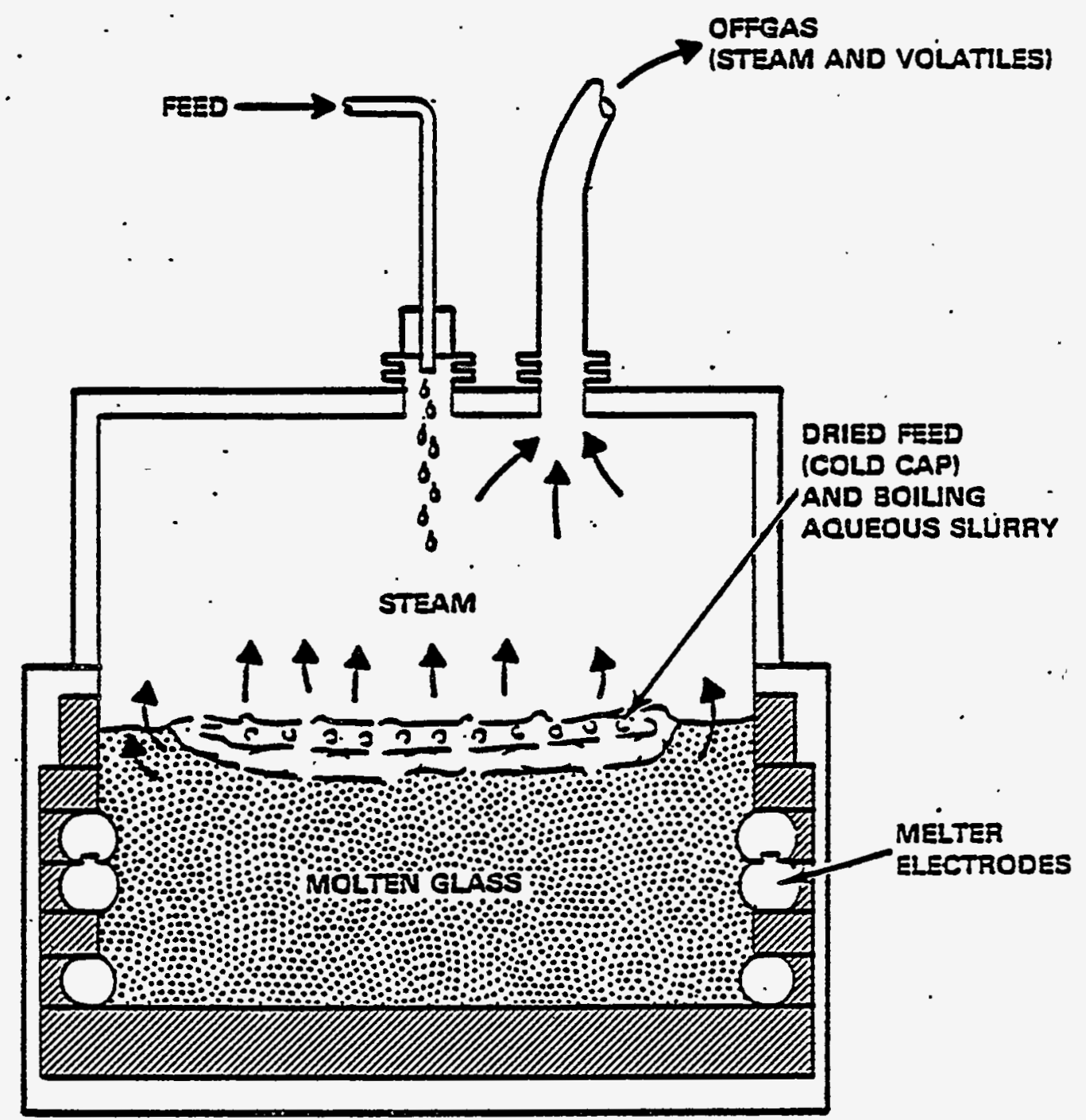

FIGURE 1. - Liquid-Fed, Joule-Heated Ceramic Melter System

waste loading of $25 \mathrm{wt} \%$, is transferred, via an overflow port, to metal canisters that are subsequently cooled and then sealed to further isolate the immobilized waste form.

To fully understand the functional requirements of the off-gas system supporting this process, the dynamics of the slurry glass-making.operations need to be discussed. Conversion of aqueous siurry to a vitreous product takes place in three distinct steps: the slurry is dried, calcined (oxidized), and then melted to form glass. During continuous feeding a "cold cap" forms within the melter that covers a large portion of the glass 
surface. The composition of this cold cap varies from slurry, on the cold cap surface, to multi-component calcine at the cold cap/glass interface. Because this is a continuous process, the steam and volatile reaction and decomposition products formed during the first two steps need to be continuousiy removed from the melter cavity by the melter off-gas (MOG) system.

Although the evaporation and calcination processes occur continuousiy, their instantaneous rates vary over a rather large range. This is because the cold cap structure is not dynamically stable (although, at steady state, its average size is) and aqueous slurry often flows out onto hot glass surfaces, which produces flashes of steam and gaseous oxides. The turbulence that results often hurls feed and glass material up into the melter plenum (the melter vapor space above the glass p001), where it can become entrained in gas currents and lost to the process exhaust. In addition to the gaseous and entrainment losses associated with LFCM proçessing, smoke generation resulting from high-temperature $\left(1050^{\circ} \mathrm{C}\right)$ volatilization and rapid condensation is also a significant loss mechanism associated with an important class of slurry components known as the semivolatiles.

The characteristics and the relative importance of each of these LFCM effluent loss mechanisms will now be discussed in terms of major chemical and radiological components of HLLL.

\section{LFCM EFFLUENT EMISSION CHARACTERISTICS}

Emission characteristics of LFCMs are normal7y discussed in terms of the three main effluent categories: gases, semivolatiles, and aerosols. Common LFCM effluent elements and compounds that fall into these categories, as well as some important radioactive isotopes associated with them, are identified below. Aerosol emission is responsible for LFCM processing losses of both semi- and nonvolatile waste components. However, the nature of the aerosols generated by these two effiuent classes is so different that the members of each group place unique and distinctive processing requirements upon the LFCM off-gas treatment system, as wi11 be discussed in subsequent sections. 


\begin{tabular}{|c|c|c|c|}
\hline \multicolumn{2}{|c|}{ Gases } & Semivolatiles & Nonvolatiles \\
\hline $\mathrm{H}_{2}$ & $\left(3_{H}\right)$ & Cs $\quad\left({ }^{137} \mathrm{Cs}\right)$ & A1 \\
\hline $\mathrm{O}_{2}$ & & $c d \quad\left(115 m_{c d}\right)$ & $\mathrm{Ce}$ \\
\hline co & $\left({ }^{14} c\right)$ & $\mathrm{Hg}$ & $\left({ }^{55} \mathrm{Fe}\right)$ \\
\hline $\mathrm{CO}_{2}$ & $\left({ }^{14} c\right)$ & (106Rut) & Si \\
\hline No & & $\left({ }^{125} \mathrm{Sb}\right)$ & sr $\quad\left({ }^{90} s r\right)$ \\
\hline $\mathrm{NO}_{2}$ & & & Rare earths $\left({ }^{\left.155_{\mathrm{Eu}}\right)}\right.$ \\
\hline $\mathrm{SO}_{2}$ & & ( $\left.{ }^{99} \mathrm{Tc}\right)$ & $u(a) \quad(238 v)$ \\
\hline $\mathrm{H}_{3} \mathrm{BO}_{3}$ & & & $\mathrm{Pu}(\mathrm{a}) \cdot\left({ }^{239} \mathrm{pu}\right)$ \\
\hline $\mathrm{H}_{2} \mathrm{O}$ & $\left({ }^{3} H\right)$ & Halides $\left({ }^{129} I\right)$ & Transuranics $(\mathrm{a})\left(241_{\mathrm{Am}}\right)$ \\
\hline$x_{2}$ & $\left({ }^{129} I\right)$ & $\mathrm{Ni} \quad(63 \mathrm{Ni})$ & Many others \\
\hline$H X$ & $\left({ }^{129} \mathrm{I}\right)$ & & \\
\hline
\end{tabular}

(a) Assumed behavior--LFCM experimental data lacking.

Although the above categorization is fairly representative of average LFCM effluent behavior, it is not rigorously correct; most elements can exhibit properties of more than one effluent class, depending on the chemistry occurring in the cold cap and in the plenum. For example, Ru can - exhibit volatile, semivolatile, or nonvolatile behavior, according to whether the melter feed is strongly oxidizing, reducing, or strongly reduced, respectively. Silicon and uranium, both classic nonvolatiles, can, in principle, be volatilized from the cold cap under certain melter conditions when a fluoride-containing feed is being processed. Whether these volatiles persist or react and/or condense (volatile or semivolatile behavior) depends on coldcap and plenum chemistry--temperature and compositional conditions. The following detailed discussion of LFCM off-gas effluent emission characteristics covers the DWPF, WVDP, and HWVP processes.

\section{Gaseous Emission}

The effluent gases evolved during melter processing are primarily caused by the presence of chemical additives used in waste processing $\left(\mathrm{H}_{2} \mathrm{O}, \mathrm{NO}_{3}{ }^{-}\right.$and $\mathrm{SO}_{4}^{\mathrm{B}}$ ) or in feed conditioning (water, boron oxide, and organics). Because 
boron, carbon, hydrogen, nitrogen, and sulphur all possess a variety of volatile compounds, melter exhaust composition will vary depending on the nature of the feed stream, melter inleakage, plenum temperature, and the chemical forms of the effluents in the feed.

The chemical properties of the feed component elements and their slurrybased compounds are very influential in establishing relative proportions of the various gaseous byproducts produced during LFCM feed processing. This fact is illustrated by the behavior of carbonaceous reductants in the feed. When formic acid is used in LFCM feeds, flammability hazards associated with $\mathrm{H}_{2}$ and $\mathrm{CO}$ in the quenched melter exhaust become a process concern that needs to be evaluated. The combustibility hazard associated with the use of formic acid is dependent upon the quantities used. Partial substitution of equivalent quantities of a more thermally and chemically stable reductant, such as sugar, cornstarch, oxalic acid and/or coal has been sucessfully used to limit combustible gas generation rates and el iminate combustibility hazards. Of course, other operational parameters, such as plenum temperature and melter inleakage, can aiso be used to influence melter exhaust gas composition. The DHPF utilizes lid heaters in the vapor space above the glass melt (the plenum) and air injection to increase or "boost" processing rates and establish plenum conditions that will efficiently oxidize gaseous combustibles before they are conveyed into the off-gas system.

The effect of plenum lid heaters upon the melter exhaust composition is i1lustrated in Figure 2, which characterizes results from a PNL melter test conducted in support of the DWPF (Goles and Sevigny 1983a). This test employed $100 \mathrm{~h}$ of radiant $7 \mathrm{id}$ heat boosting, followed by $20 \mathrm{~h}$ of unboosted operation. The high plenum temperatures associated with 1 id heating have a definite controlling influence on the combustible gases $\mathrm{CO}$ and $\mathrm{H}_{2}$. The data presented in this figure also illustrate that melter emissions are not generated smoothiy or continuousiy even under the most controlied operational conditions. This behavior is a result of the nonuniform way in which melter feed is dried, oxidized, and melted during the liquid feeding process. Variations in.melter gas generation rates (surging) usually occurs when dammed-up liquid feed lying atop an insulating layer of dry feed (the cold cap) abruptly flows out upon a hot glass surface. The liquid quickly flashes 


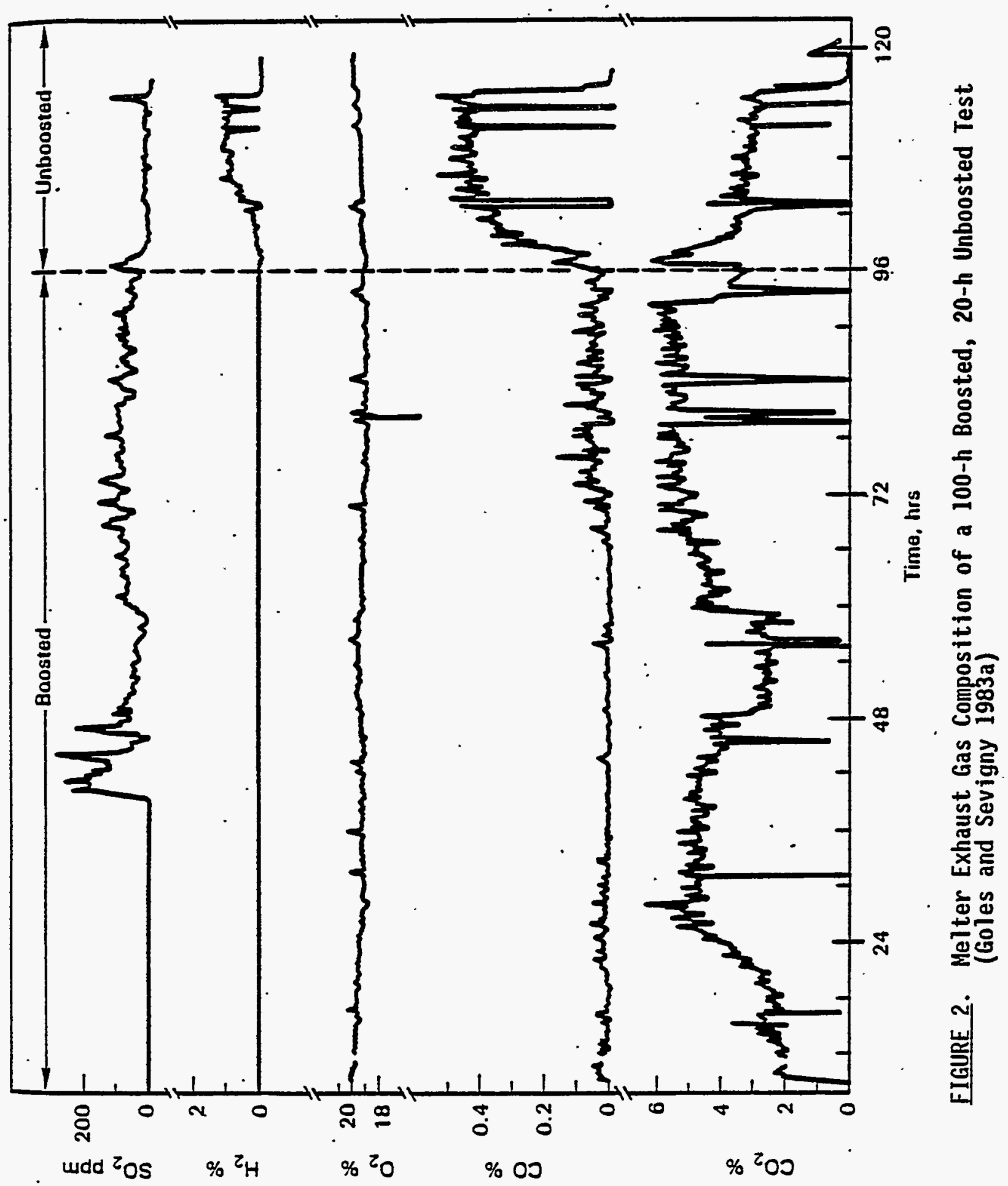


off this hot surface, producing a flow pulse composed of steam and volatile decomposition/reaction products. The frequency and/or extent of these excursions is related to the physical properties of the feed which, in turn, are composition-dependent. Figures 3 and 4 illustrate the behavior of some of the more important melter-generated gases accompanying flow surges. The frequency and magnitude of these surges are positive indicators of melter system instabilities, which are most often associated with nonuniform or excessive feeding. One of the instabilities is reboil (see Figure 4), which is. caused by rapid oxidation state changes in glass components, and involves rapid evolution of oxygen from the glass pool.

The correlation between the emission rates of noncondensible gases and steam flow surges suggests a prompt evolution of combustible gases from the cold cap. Figures 5 and 6 portray the time-dependent compositional behavior of the melter exhaust streams upon feed interruption or termination. With the exception of $\mathrm{SO}_{2}$, none of the melter-generated gases increased-in concentration when feeding was terminated. Consequently, a dry cold cap has not been observed to produce combustibility hazards that are greater than those aiready existing during normal liquid feeding.

Other chemical additives such as the halogens are also evolved predominantly as gases in the DWPF, WVDP, and HWVP processes. Mercury, a significant. chemical component in SRP defense waste, has been found in PNL (ESCM) studies to be strongiy ( $250 \%$ ) volatilized from LFCMs as mercurous halides, while only $1 \%$ of boron, a common glass-forming additive in all three processes, volatilizes as $\mathrm{H}_{3} \mathrm{BO}_{3}$ during $\mathrm{LFCM}$ feed processing. The greatest volumetric contributior to LFCM gaseous emissions is of course steam, which is generated from the water content of the slurry feed.

The radiological impact of LFCM gaseous effluent losses is primarily due to the presence of ${ }^{3} \mathrm{H},{ }^{14} \mathrm{C}$, and ${ }^{129} \mathrm{I}$ in HLLH. Because the vitreous product has a negligible capacity for hydrogen and carbon, essentially all ${ }^{3} \mathrm{H}$ and ${ }^{14} \mathrm{C}$. in the melter feed stream is lost to the off-gas processing system as steam (tritiated water, HTO) and as oxides of carbon $\left({ }^{14} \mathrm{CO}_{\mathrm{X}}\right)$, respectively. Similarly, large process losses of iodine ( $>50 \%$ ) have been observed (PSCM-22) due to the volatility of its elemental and chemically combined forms 


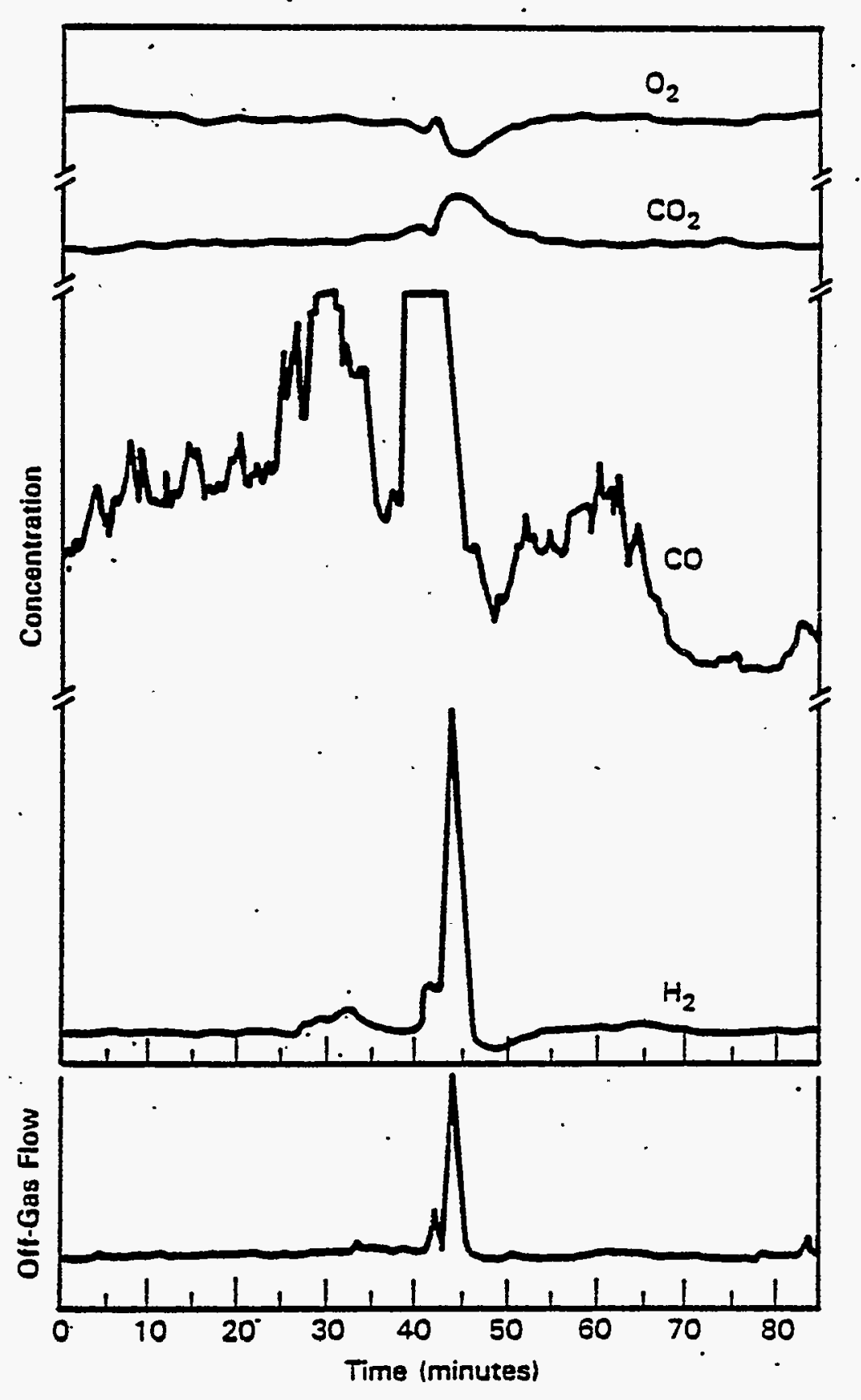

FIGURE 3. Compositional Behavior of Noncondensible Melter Exhaust Gases Accompanying a Flow Surge. (Maximum extent of the surge event: flow: $3 \mathrm{X} ; \mathrm{H}_{2}<3.5 \% ; \mathrm{CO} \gg 0.5 \% ; \mathrm{CO}_{2}-15 \% ; \mathrm{O}_{2}-17 \%$ ) (Goles and Sevigny 1983) 

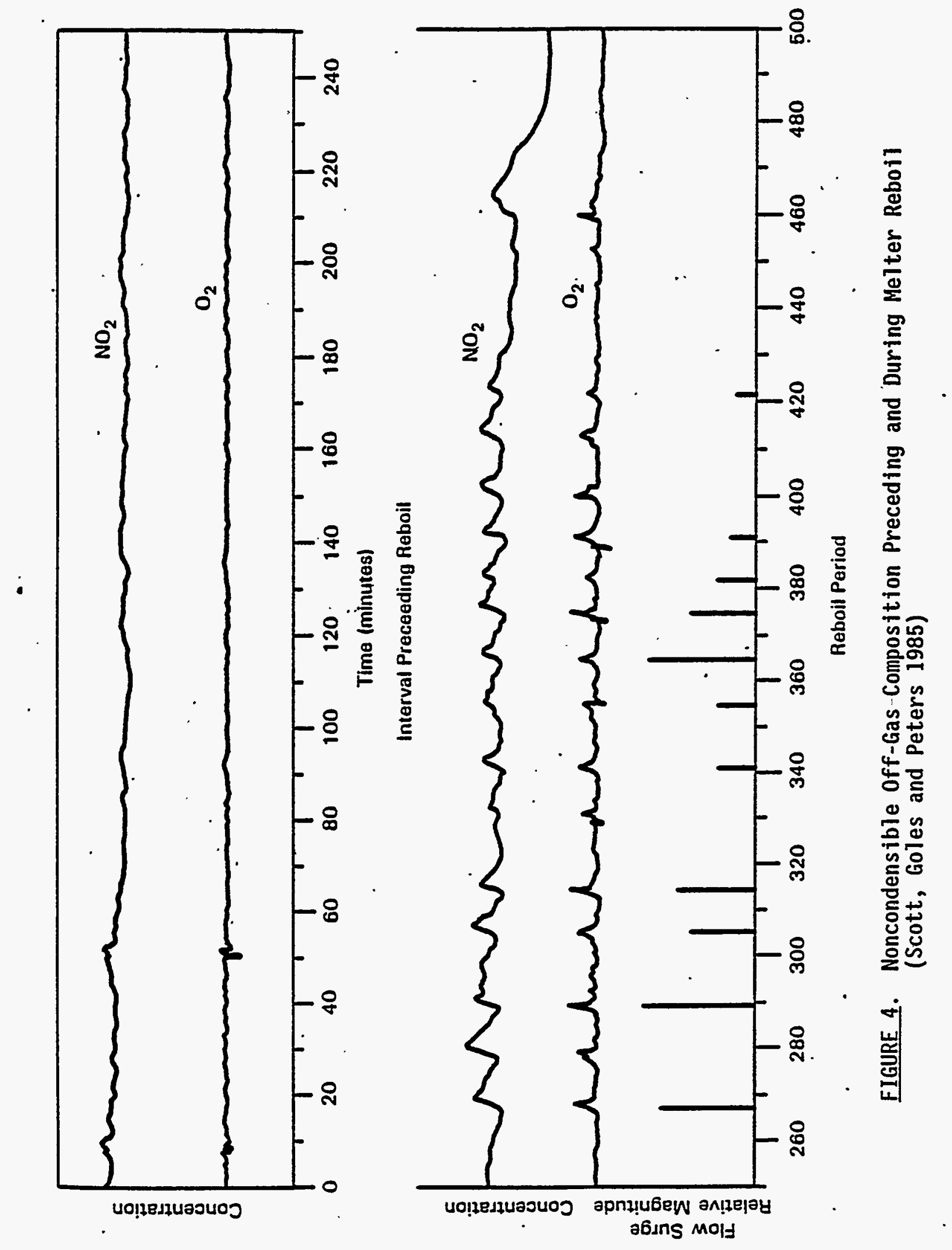


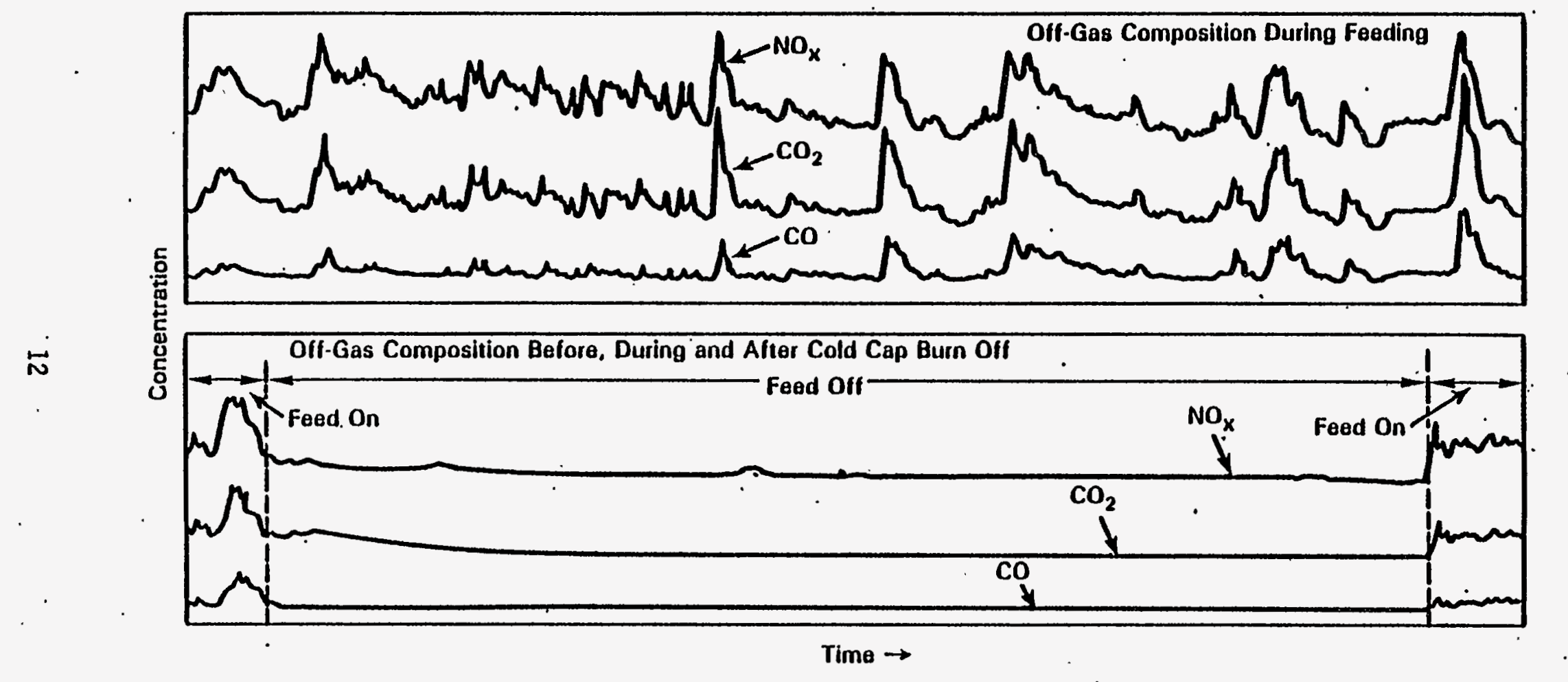

EIGURE 5. Compositional Behavior of Exhaust Stream Upon Feed Interruption (Scott, Goles and Peters 1985) 


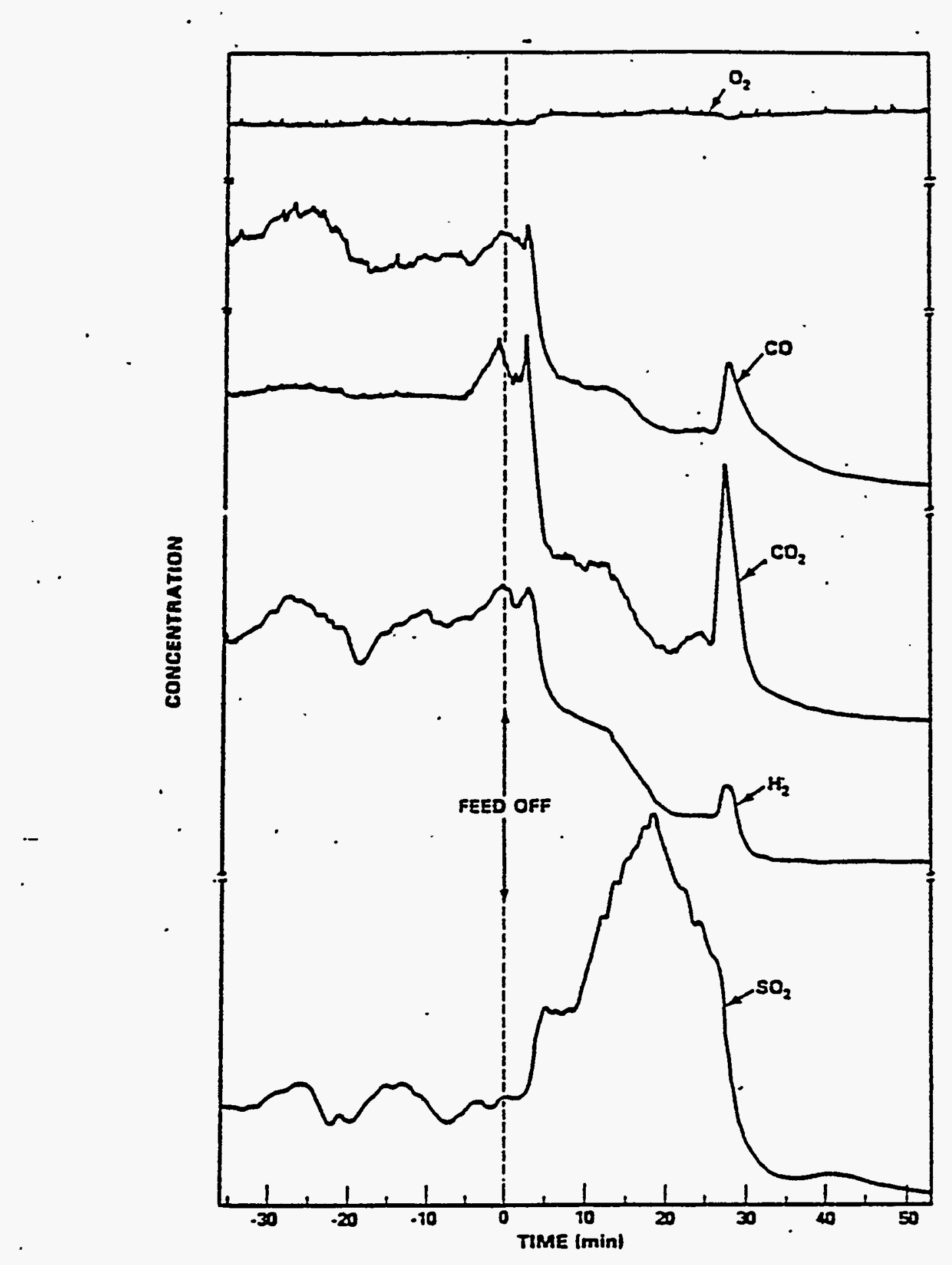

FIGURE 6. Melter Off-Gas Compositional Behavior Associated with Feed Termination. (The $t=30$ min compositional spike is due to the injection of a small quantity of liquid feed.) (Goles and Sevigny 1983) 
(Nakaok 1985). Since the glass capacity for iodine is expected to be quite low, process models usually assume $100 \%$ volatility losses for this element.

\section{Aerosol Emission}

From. the previous discussion it is quite clear that LFCM gaseous effluent losses are limited to only a very few waste components, and of these only hydrogen $\left({ }^{3} \mathrm{H}\right)$ and carbon $\left({ }^{14} \mathrm{C}\right)$ are exclusively lost by this escape mechanism. The loss rates of essentially all other melter feed components are influenced, to a greater or lesser extent, by aerosol (airborne particulate) escape. This fact is clearly illustrated in Table 1, which summarizes typical LFCM off-gas emission data. The values listed in this table are melter decontamination factors (DFs), which are ratios of the rate at which feed components enter the melter, to the rate at which they are evolved. Particulate DFs are partial DFs relating to only a single loss mechanism: aerosol emission. The data presented in this abridged tabie clearly show that melter gas-phase losses to the off-gas system are only significant for $\mathrm{Cl}, \mathrm{S}$, and $\mathrm{B}$, which readily form yolatile acid gases as previously discussed.

IABLE 1. Melter DFs for Particulate and Total Feed Component Using Formated Melter Feed (Goles and Sevigny 1983)

\begin{tabular}{lccc} 
& \multicolumn{2}{c}{ Average DF } \\
\cline { 4 - 4 } Element & & Particulate & Total \\
\cline { 4 - 4 } AT & 27,000 & 22,000 \\
B & 6,800 & 100 \\
Cd & 9.9 & 9.9 \\
CT & 21 & 2.9 \\
CS & 14 & 14 \\
Fe & 1,900 & 1,800 \\
La & 2,100 & 2,100 \\
Mn & 1,800 & 1,800 \\
Na & 300 & 300 \\
S & 11 & 5.5 \\
Sr & 1,800 & 1,800 \\
Te & 3.0 & 3.0 \\
Zr & 22,000 & 22,000
\end{tabular}


Melter-induced volatilization also influences LFCM loss rates of another class of waste components, which quickly react or condense in the melter plenum to form airborne particulate effluent. The low DFs associated with the semivolatile elements $C d, C s$, and $\grave{T e}$, as well as Se and $S b$, clearly underscore the importance of this volatilization process. However, Table 1 clearly shows that, apart from the mechanisms producing these airborne effluents, aerosol emission is responsible for off-gas system losses of these effluents. Transport of airborne particulate matter through the off-gas system is the predominant radiological effluent loss mechanism associated with the LFCM process.

Because most radiological melter off-gas system losses involve aerosol emission, establishing the characteristics of these aerosols is particularly important to off-gas system design. The size distribution of meltergenerated aerosols has been established at PNL using a cyclonic particlesize analysis system. Table 2 details the characteristic manner in which

TABLE 2. Size Distribution of Melter Aerosols

\begin{tabular}{|c|c|c|c|c|c|}
\hline \multirow[b]{2}{*}{ PNL Experiment No. (a) } & \multirow[b]{2}{*}{ Feed Type } & \multicolumn{4}{|c|}{ Average wt\%: } \\
\hline & & $16 \mu \mathrm{m}$ & $6 \mu \mathrm{m}$ & $1 \mu \mathrm{m}$ & $\leq \underline{\mathrm{I}} \mathrm{m}$ \\
\hline LFCM-7 & Formate DWPF & 76.7 & 2.8 & 8.5 & 11.9 \\
\hline PSCM-4 & Formate DWPF & -- & 0.9 & 3.6 & 95.6 \\
\hline PSCM-5 & Formate DWPF & 13.5 & 3.9 & 20.2 & 62.2 \\
\hline PSCM-6 & Formate DWPF & 46.1 & 0.5 & 12.7 & 40.7 \\
\hline PSCM-7 & Formate DWPF & 7.5 & 3.2 & 9.4 & 79.9 \\
\hline PSCM-8 & Formate DHPF & $4 \dot{4} .0$ & 7.3 & 19.6 & 29.1 \\
\hline PSCM-9 & Nitrate WVDP & 8.2 & 2.1 & 16.3 & 73.7. \\
\hline PSCM-15 & Nitrate HVDP & 44.7 & 9.8 & 22.4 & 23.1 \\
\hline PSCM-20 & High Cs WVDP & 1.7 & -- & 12.5 & 85.8 \\
\hline PSCM-23 & Formate HWVP & 29.6 & 5.2 & 18.8 & 46.4 \\
\hline
\end{tabular}

(a) PSCM = pilot-scale ceramic melter. - - Data below detection limit. 
melter particutate matter is found to be distributed across the cyclonic sample fractions for various pilot-scale melter experiments conducted with DWPF, WVDP, and HWVP simulated feed streams. Al1 melter tests, in general, exhibited aerosol-size distributions that were bimodal. This result suggests that the overall aerosol effluent size distribution is composed of two independent components, each having its own characteristic size distribution. Gross compositional dissimilarities between the discrete cyclonic size fractions shown in Table 3 strongly reinforce this argument. Moreover, because the submicron size fraction shown in this table (LFCM-7) contains only 12\% of the total sample mass, but possesses essentialiy all the semivolatile matter of the sample, the mechanism responsible for the smal1-diameter component of the overall distribution is probably a volatilization/condensation process that occurs within the melter plenum. The compositions of the large cyclonic size fractions are very similar to those of the slurry feed, as shown in Table 4. Consequently, the large component of the bimodal distribution is most certainly associated with a gross entrainment mechanism.

Because, on the average, greater than 50\% of the LFCM particulate offgas system losses are associated with aerosols having aerodynamic diameters of $1 \mathrm{\mu m}$ and less, and because essentially all the radiologically important semivolatiles are concentrated in these fractions, melter design parameters such as plenum freeboard and exhaust port and feed nozzle positioning have little or no effect- on off-gas processing design criteria.

\section{Melter Emission Performance}

Because most melter off-gas system losses have been shown to be associated with aerosol emission, the off-gas performance (DF) of LFCMs is conveniently measured in terms of gross (total) off-gas aerosol losses. The affects of various processing variables upon melter performance has been extensively studied during cold, scaled simulation testing of the LFCM process. The affect of these variables upon melter losses are discussed below.

\section{Cold Cap Coverage.}

A comparison of the average gross melter DFs obtained from the numerous melter tests conducted at PNL reveals that, irrespective of feed type, when a 
IABLE 3. Typical Elemental Distribution Across the Cyclonic Sampling System (Goles and Sevigny (1983)

\begin{tabular}{|c|c|c|c|c|}
\hline \multirow[b]{2}{*}{ Element } & \multicolumn{4}{|c|}{ Distribution, \% } \\
\hline & $16 \mathrm{~lm}$ & $6 \mathrm{~m}$ & $1 \mathrm{~mm}$ & $\leq 1 \mathrm{Lm}$ \\
\hline Al & 96.2 & 0.9 & 2.5 & 0.4 \\
\hline B & 87.8 & 1.8 & 7.8 & 2.6 \\
\hline $\mathrm{Ba}$ & 83.7 & 5.8 & 10.5 & 0 \\
\hline $\mathrm{Ca}$ & 77.7 & 2.7 & 15.2 & 4.4 \\
\hline Cd & 10.7 & 0.8 & 7.9 & 81.2 \\
\hline $\mathrm{Ce}$ & 92.1 & 0 & 7.9 & 0 \\
\hline $\mathrm{Cr}$ & 46.4 & 21.7 & 23.3 & 8.6 \\
\hline Cs & 7.5 & 0 & 5.4 & 87.1 \\
\hline $\mathrm{Cu}$ & 82.6 & 4.9 & 4.2 & 8.3 \\
\hline $\mathrm{Fe}$ & 77.3 & 2.6 & 7.0 & 3.1 \\
\hline La & 91.9 & 1.5 & 6.1 & 0.5 \\
\hline Li & 83.2 & 1.5 & 5.3 & 10.0 \\
\hline $\mathrm{Mg}$ & 91.5 & 1.6 & 5.8 & 1.1 \\
\hline Mn & 89.4 & 6.4 & 3.6 & 0.6 \\
\hline Mo & 77.5 & 5.6 & 9.8 & 7.1 \\
\hline $\mathrm{Na}$ & 68.8 & 1.7 & 5.6 & 23.9 \\
\hline Nd & 93.4 & 0 & 6.6 & 0 \\
\hline $\mathrm{Sb}$ & 100.0 & 0 & 0 & 0 \\
\hline Se & 56.9 & 1.9 & 11.4 & 29.8 \\
\hline Si & 92.0 & 1.8 & 5.6 & 0.6 \\
\hline Sr & 77.6 & 2.8 & 19.6 & 0 \\
\hline $\mathrm{Te}$ & 5.5 & 0.4 & 3.2 & 90.9 \\
\hline$T_{i}$ & 91.2 & 1.8 & 6.0 & 1.0 \\
\hline$Z r$ & 91.6 & 1.6 & 5.6 & 1.2 \\
\hline
\end{tabular}


TABLE 4. Composition of 16- $2 \mathrm{~m}$ Cyclonic Sample Fraction - (Goles and Sevigny 1983)

\begin{tabular}{|c|c|c|}
\hline Elementa] & Weight & cent \\
\hline Qxides (a) & $16 \mathrm{\mu m}$ & Feed \\
\hline $\mathrm{Al}_{2} \mathrm{O}_{3}$ & 3.4 & 5.1 \\
\hline $\mathrm{B}_{2} \mathrm{O}_{3}$ & 9.0 & 10.5 \\
\hline CaO & 1.6 & 1.7 \\
\hline $\mathrm{Fe}_{2} \mathrm{O}_{3}$ & 14.4 & 12.7 \\
\hline $\mathrm{La}_{2} \mathrm{O}_{3}$ & 0.3 & 0.4 \\
\hline $\mathrm{LiO}_{2}$ & 3.5 & 4.1 \\
\hline $\mathrm{MgO}$ & 1.1 & 1.4 \\
\hline Mno & 3.2 & 2.9 \\
\hline $\mathrm{Na}_{2} \mathrm{O}$ & 13.0 & 13.6 \\
\hline $\mathrm{SiO}_{2}$ & 38.0 & 45.6 \\
\hline $\mathrm{TiO}_{2}$ & 0.7 & 0.7 \\
\hline Zro & 0.3 & 0.4 \\
\hline
\end{tabular}

(a) Assumed oxide forms.

melter is fed conservatively (underfed with a cold cap coverage of ${ }^{\circ} 90 \%$ ) due to either experimental design or system 1 imitations, extremely high glass conversion efficiencies and aerosol DFs result. Conversely, experiments punctuated by erratic or overfeeding conditions (cold cap coverage $₫ 90 \%$ ) have, in general, exhibited the poorest off-gas emission performance. In between these two extremes lies the majority of melter tests conducted at PNL, where feeding rates were carefulty ramped to produce stable steady-state operating conditions that matched feeding and glass production rates at $-90 \%$ cold cap coverage. Table 5 compares emission data obtained from LFCM tests conducted under all three types of feeding conditions: conservative and steady, cold cap $\times 90 \%$; steady state, $-90 \%$ cold cap coverage; and overfeeding and/or erratic, cold cap $₫ 90 \%$.

\section{Feed Rate Boosting}

It is clear from a process engineering standpoint that a continuous steady-state feeding condition is the most desirable of the three operating 
TABLE 5. Meiter Performance Under Various Processing Conditions

\begin{tabular}{|c|c|c|c|}
\hline Processing Conditions & Feed Type & Test & $\mathrm{DF}$ \\
\hline Conservative \& Steady & $\begin{array}{l}\text { Alkal ine DWPF } \\
\text { Formic DHPF } \\
\text { Formic HWUP }\end{array}$ & $\begin{array}{l}\text { PSCM-1 } \\
\text { PSCM-3 } \\
\text { HWVP-23 }\end{array}$ & $\begin{array}{r}1100 \\
980 \\
1500\end{array}$ \\
\hline 90\% Cold Cap \& Steady & $\begin{array}{l}\text { Formic DWPF } \\
\text { Nitrate WVDP } \\
\text { Formic HWVP } \\
\text { Formic HWVP }\end{array}$ & $\begin{array}{l}\text { PSCH }-4 \\
\text { PSCM-9 } \\
\text { HB85-1 } \\
\text { PSCM-23 }\end{array}$ & $\begin{array}{l}490 \\
420 \\
430 \\
330\end{array}$ \\
\hline Overfed and/or Erratic & $\begin{array}{l}\text { Alkal ine DHPF } \\
\text { Formic DHPF } \\
\text { Nitrate HWDP }\end{array}$ & $\begin{array}{l}\text { LFCM-6 } \\
\text { LFCM-7 } \\
\text { PSCM-16 }\end{array}$ & $\begin{array}{l}180 \\
120 \\
160\end{array}$ \\
\hline
\end{tabular}

alternatives. The maximum feeding rates achievable for a given melter under steady-state conditions can be and have been increased (boosted) through use of auxiliary plenum heaters. The effect of feed boosting on melter performance has been studied under controlled steady-state conditions. These tests were designed to establish the relationships, if any, between absolute feed rates and melter $D F$.

Table 6 presents gross aerosol DF values associated with the boosted PSCM-5 and PSCM- 6 tests. These data show no correlation between feed rates and DFs. Moreover, the boosted PSCM- 6 experiment did not utilize electric radiant lid heaters for the entire melter test, yet no significant differences in normalized melter emission rates (DFs) were observed throughout the experiment. Consequently, these data suggest that the use of electric radiant plenum heaters can be employed to boost processing rates of liquid feed rates of ceramic melters without significantly affecting melter (DF) performance.

Air-sparge-induced glass convection has also been used to boost LFCM steady-state feed rates. The results obtained from the 1 imited tests conducted indicate that, at worst, a slight lowering of melter DF may result because of increases in gross entrainment. These losses are, however, readily removed by the first stage quench scrubber. The overal1 DF across the melter and quench scrubber has not been found to be significantly affected by forced-convective feed rate boosting techniques. 
IABLE 6. Steady-State Aerosol Emission Characteristics

PSCM-5 Boosted Test

Sample

Feed Particulate

Rate, Loadjing,

Identification

$\begin{array}{lccc}\text { A } & 51 & 0.55 & 470 \\ \text { B } & 72 & 0.49 & 460 \\ \text { C } & 79 & 0.44 & 510 \\ \text { D } & 81 & 0.61 & 440 \\ \text { E } & 81 & -. & 370 \\ \text { F } & 86 & 0.48 & 492 \\ \text { G } & 93 & .0 .48 & 440 \\ \text { H } & 93 & -- & 670\end{array}$

Overal7 Average
PSCM-6 Boosted and Unboosted Test

Feed Particulate

Sample

Rate, Loadjing,

Identification L/h $\mathrm{mg} / \mathrm{L}(a)$ DF

$68 \cdot 0.29 \quad 820$

$68 \quad-. \quad 810$

B $\quad 68 \quad \cdots \quad 810$

$\begin{array}{llll}\text { C } & 67 & 0.37 & 840\end{array}$

$\begin{array}{llll}D & 74 & 0.25 & 910\end{array}$

E $\quad 90 \quad 0.41 \quad 700$

F $\quad 91.0 .28 \quad 840$

G $\quad 90 \quad \ldots 96720$

H $\quad 58^{\text {(b) }} \quad 0.32 \quad 870$

I

0.54660

Overall Average :-..................- 800

(a) STP.

(b) Unboosted operation.

-. Indicates data not available.

\section{Feed Composition}

It has been shown previously (Table 2) that physical characteristics of LFCM-generated aerosols are nominal1y independent of feed compositions. However, the composition and magnitude of these emissions are dependent upon the physical and chemical nature of the slurry feed. Indeed, of all the parameters that can affect LFCM performance, feed composition is the most important. Ironical1y, the feed components that have the greatest influence upon melter exhaust characteristics are traditionally chemical additives used in waste processing (nitrates, sulfates, and the halogens) or in feed conditioning (organics--sugar, formic acid, etc.). These chemical additives directly influence the magnitude of MOG system losses resulting from both entrainment and volatilization.

Physical Affects. There are several mechanisms by which melter entrainment is affected by feed composition. The physical ability of feed components to form a structurally sound insulating layer between the incoming 
feed and the hot glass surface is one of the more important factors influencing melter processing stability and, consequently, the magnitude of off-gas entrainment losses. Ideal1y, upon entry into an LFCM, the waste components of the slurry feed would be dried, calcined, and melted in a smooth continuous process to form a molten borosilicate glass. In reality, structural collapse of the cold cap often brings dammed-up liquid feed into contact with extremely hot glass surfaces, which results in the flashing off of steam and volatile reaction products. The nonuniform pulsed flow that results increases entrainment losses. The degree and frequency with which this occurs is a composition-dependent property of the feed. The formating of hydroxide slurry feeds has, for example, been found (Goles and Sevigny 1983a,b) to significantly improve cold cap melting and LFCM processing characteristics. On the other hand, melter glass reboil initiated by highly oxidized feeds (a chemical property) produces destabilizing effects by causing cold cap collapse. Figure 4 demonstrates the smooth and disruptive flow patterns associated, respectively, with stable and unstable melter processing (cold cap) conditions.

The importance of entrainment upon overall cesium loss rates depends upon the corresponding magnitude of, cesium volatilization losses which, as - will be seen, are also compositionally dependent. Since the range of melter cesium DFs. is nominalily an order of magnitude lower than the observed range of overall aerosol DFs, a feed possessing low volatility would have to also produce extremely high entrainment losses in order to significantly influence me1ter cesium DF. This has never occurred during PNL LFCM testing; however, it is certainiy possible.

Chemical Affects. The influence of feed composition upon melter semivolatile losses is clearly demonstrated by the order of magnitude range in observed cesium DFs. As previously discussed (see Table 1), melter losses of cesium and other semivolatiles are dominated by a volatilization/condensation loss mechanism. Consequently, processing stability has little to do with observed melter cesium performance. As a result, the differences in observed cesium DFs must logically be associated with factors affecting volatilization rates. Since plenum temperature and cold cap glass coverage have been previously shown to be unrelated to cesium DF, the chemistry in the 
cold cap must be responsible. For most semivolatiles, inciuding cesium and mercury, the halogen feed components appear to determine and limit volatilization rates. In most PNL tests; the halogen chlorine was introduced into the LFCM slurries as an impurity in the $\mathrm{Fe}(\mathrm{OH})_{3}$ feed component. The variability in semivolatile alkali element DFs, moreover, has been found to be directly related to the availability of chlorine in the feed stream. This of course implies that LFCM-generated emissions of the alkali elements, including cesium, are predominantiy composed of chlorinated (halogenated) compounds. The fact that the chlorine (halogen) content of aerosol effluent varies directly with its alkali content, strongly supports this supposition, as is shown in Table 7 (Goles 1986).

TABLE 7. Melter Performance as a Function of Chlorine wt\%

\begin{tabular}{|c|c|c|c|c|}
\hline \multirow[b]{2}{*}{ PNL Test } & \multicolumn{2}{|c|}{ Effluent wt\% } & \multicolumn{2}{|c|}{ DF } \\
\hline & CS & CI & Cs & Mass \\
\hline PSCH-5 & 2.2 & 56.7 & 9.5 & $490^{\circ}$ \\
\hline PSCH-4 & 1.9 & 43.4 & I6 & 630 \\
\hline PSCH-7 & 1.2 & 39.0 & 13 & 870 \\
\hline $\operatorname{PSCH}-g(a)$ & 2.0 & 33.1 & 14 & 460 \\
\hline PSCH-6 & 2.4 & 25.0 & 14 & 860 \\
\hline PSCH-22 & 6.1 & $>12.6$ (b) & 14 & 330 \\
\hline PSCH-8 & 0.34 & 10.0 & 130 & 940 \\
\hline PSCH-21 & 0.57 & 7.2 & 33 & 200 \\
\hline PSCH-20 & 24 & 5.9 & 140 & 640 \\
\hline $\operatorname{PSCM}-16(a)$ & 0.30 & 5.1 & 59 & 160 \\
\hline $\operatorname{PSCH}-15(a)$ & 0.48 & 3.9 & 62 & 240 \\
\hline PSCM-19 & 0.27 & 2.3 & 97 & 370 \\
\hline
\end{tabular}

(a) These tests were highly oxidizing.

(b) Equivalent halogen content. 
Although the halogen content of LFCM feed apparently determines alkali element volatilization rates, not enough data exist to establish the exact functional relationship involved. However, this relationship, whatever form it may take, appears to be independent of the REDOX (average oxidation) state of both the feed and the glass. Cesium DFs of -10 have been observed under strongly oxidizing as wel1 as reducing LFCM processing conditions where the only common factor between tests has been a high chlorine feed composition.

The oxidizing properties of the slurry waste stream, which are usually established by chemical additives $\left(\mathrm{NO}_{3} ; \mathrm{SO}_{4}, \mathrm{HCOOH}\right.$, etc.), are also quite influential in establishing the melter performance for radiologically important elements having volatile oxides. Specifically, highly oxidizing feeds and resultant glasses promote melter volatilization losses of ruthenium, technetium, and iodine isotopes. Reducing feeds, on the other hand, are found to totally suppress Ru and Tc volatility to the point that off-gas sys- tem losșes are established by physical entrainment escape mechanisms. This is not true for iodine, however.

\section{Emissions During Melter Idling}

When an LFCM is not processing slurry feed, it is said to be idling. In order to establish the importance of idling upon the overall melter source term, effluent emission characteristics associated with the idling state have been extensively studied at PNL (Goles and Sevigny 1983a,b). If the idling state is considered to begin when liquid slurry feeding is terminated, the melter source has both short- and long-term emission characteristics, which are graphically displayed in Figure 7. With an unboosted melter, cesium as well as overall emission rates decrease rapid7y as the existing cold cap is consumed. Once the cold cap has dissolved, the melter plenum temperature begins to increase over several days from a processing condition of $200^{\circ} \mathrm{C}$ to a steady-state value of $1000^{\circ} \mathrm{C}$. During this period, feed deposits on the plenum surfaces, which are enriched. in semivolatiles, burn away and produce the peak in idling emission rates that is most pronounced for the semivolatile elements, especialty cesium. The pulsed emission characteristics of individual feed components are determined solely by their semivolatile 


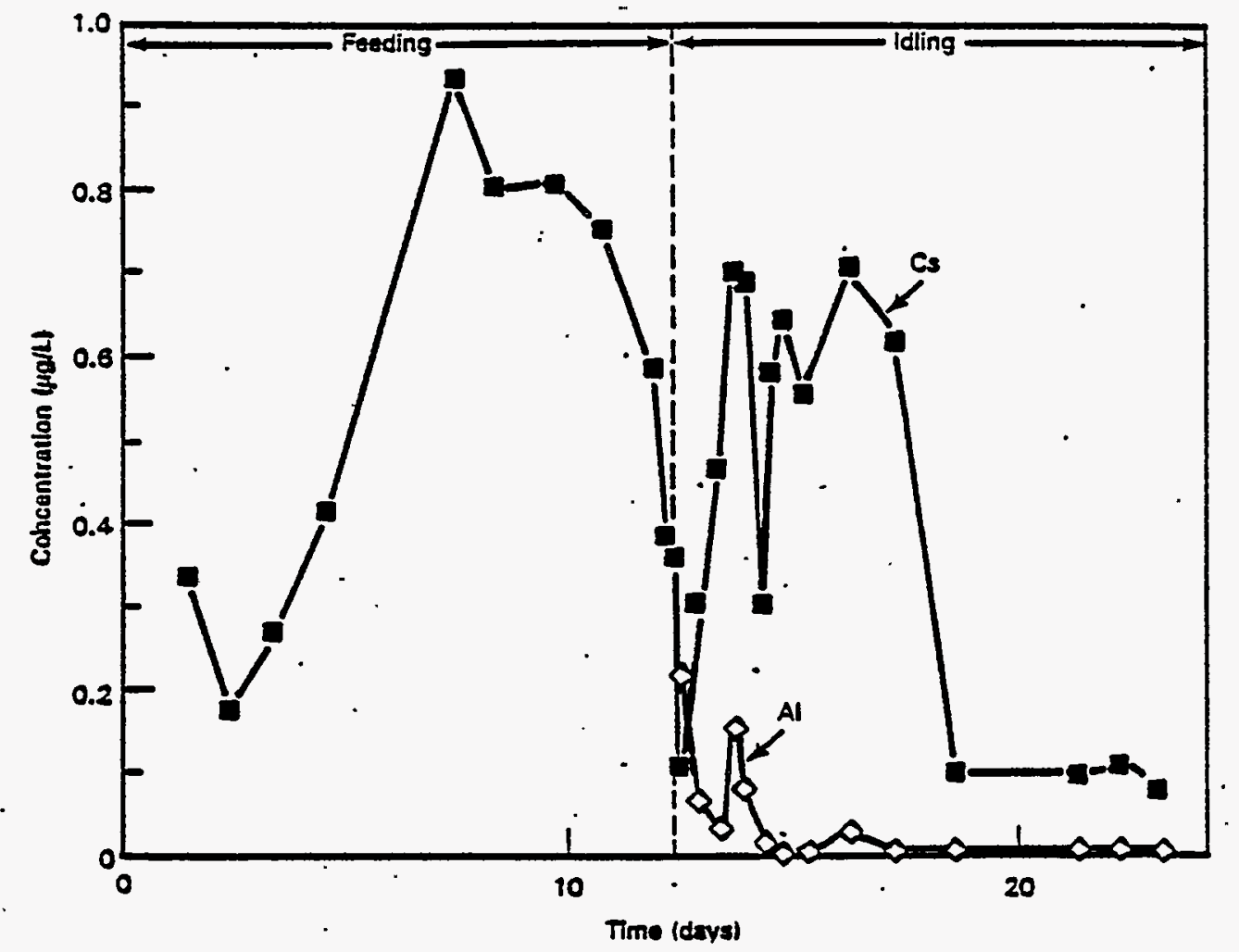

FIGURE 7.' Melter Off-Gas Emission Characteristics (Goles 1986)

nature. Consequently, two distinct sets of plenum burn-off peaks are observed, which are associated with semivolatiles or nonvolatiles.

The apparent temperature-dependent emission characteristics associated with nonvolatiles arise from the entrainment produced from the temperaturedependent melting of plenum surface deposits and the resultant turbulence produced by plenum debris failing back into the hot glass pool. Since the magnitude of entrainment induced by burn-off is only $-1 \%$ of that occurring during feed processing, Figure 7 only presents nonvolatile idling emission properties so as not to suppress the other data presented.

The burn-off characteristics of all the semivolatile alkali elements are essentially identical except for their magnitudes; this is consistent with a tota11y temperature-dependent phenomenon. Moreover, the peak emission rate values during burn-off do not generally exceed their corresponding melter processing loss rates. However, plenum burn-off emission rates of trace 
semivolatile feed components such as cesium far exceed those associated with major nonvolatile feed components, which suggests that the melter plenum can and does act as a significant sink for semivolatile effluent: As a result, melter DFs derived from off-gas emission studies can overestimate LFCM glassification efficiencies for the semivolatiles.

Long-term idling emission characteristics are flat, unstructured, and only significant for semivolatiles (i.e., boron, cesium, sodium, ruthenium, and various halogenated and sulphur compounds). As Figure 7 clearly shows, these long-term semivolatile loss rates, of which cesium presents a worst case, are generally found to be significantly less than those occurring during meiter feed processing. However, the magnitudes of these emission rates are functionally dependent upon glass concentrations. Figure 8 characterizes

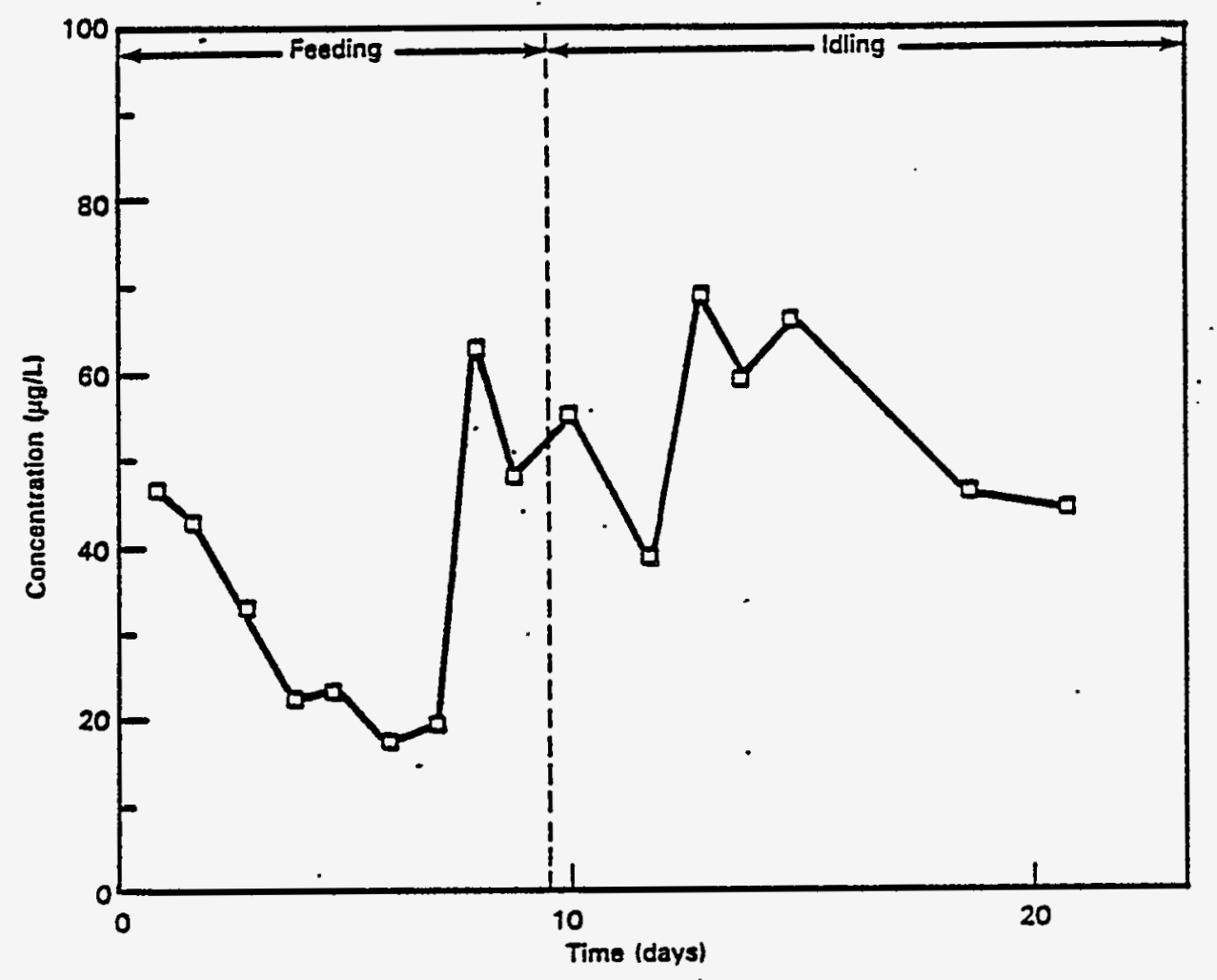

FIGURE 8. Cesium Off-Gas Emissions During and After Processing a High Cesium-Bearing Feed (PSCM-20) 
melter cesium emission rates during and after the production of a -5 wt\% cesium-loaded glass. Under these high glass-loading conditions, long-term idling emissions of cesium are seen to be nominally equivalent to the losses associated with maximum feed processing conditions. Moreover, since peak and long-term emission rates are not found to be dramatical1y different after processing the high cesium-loaded feed, it appears that the glass pool may significantly influence the melter cesium source term during all phases of idling and possibly during feed processing as well. This has never been the case for low ( $<0.5$ wt\%) cesium-bearing feeds.

Since the semivolatile idling emission characteristics of a melter are temperature-dependent, idling emission rates can be controlled by regulating the melter plenum temperature. This was demonstrated at PNL using a fine water mist plenum spray, which cooled but did not disturb the surface of the melter glass pool (Goles and Sevigny 1983). This temperaturedependence study was initiated immediately after a 120 -h liquid-fed melter test. With a $42-\mathrm{L} / \mathrm{h}$ water spraying rate and the meiter under automatic control to maintain the bulk tank temperatures approximately constant, the melter glass surface was cooled to the point that it formed a continuous, nonconvective layer above the bulk melter glass pool (with plenum at $280^{\circ} \mathrm{C}$ ). When the spray rate was decreased to $27 \mathrm{~L} / \mathrm{h}$, the surface temperatures increased and the viscosity decreased significantly. In addition, convective mixing opened vents in the glass surface that migrated at random across the glass poot. However, plenum temperatures were not high enough to melt feed deposits formed upon the melter walls and lid during the preceding melter (PSCM-5) experiment. Finaliy, the cooling spray was terminated and the 'melter was allowed to idle, which slowly brought the melter plenum up to $850^{\circ} \mathrm{C}$. Samples were collected from the plenum during all phases of this study.

The results obtained from these plenum samples are graphically summarized in Figure 9, which characterizes the emission rates of the semivolatile elements under various idling conditions (temperature) employed during this test. These data indicate that emission rates of all semivolatile elements decreased as a function of time after the completion of PSCM-5 at a $42-L / h$ 


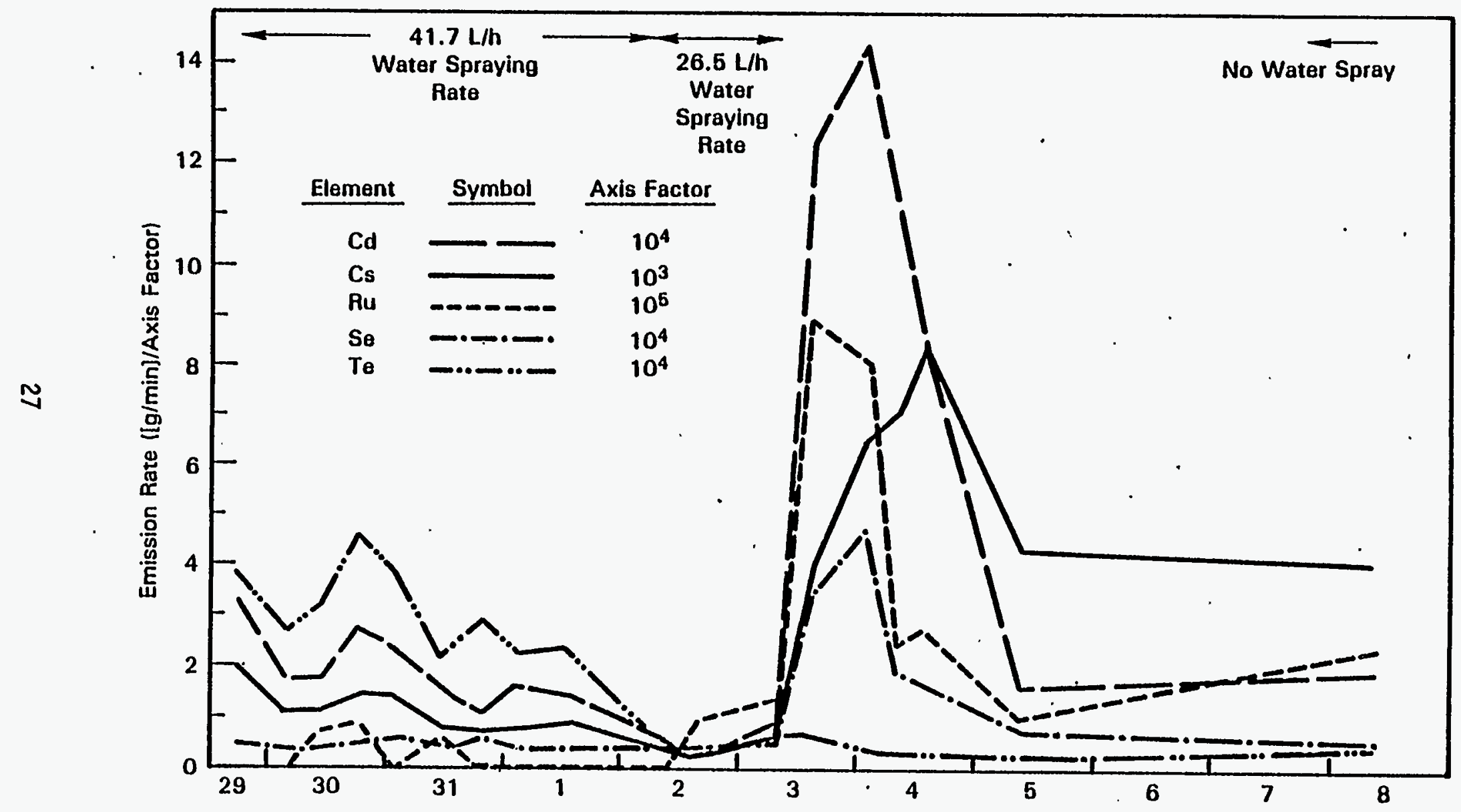

FIGURE 9. Emission Rates of Semivolatile Elements During Melter Idling 
water spraying rate. Reducing the cooling. spray rate to $27 \mathrm{~L} / \mathrm{h}$ increased both plenum temperature and semivolatile emission rates; however, an equilibrated plenum temperature was not achieved during the brief $24-\mathrm{h}$ period of reduced spraying.

- Termination of the water-cooling spray increased the plenum temperature steadiTy to the point where plenum surface deposits formed during previous feed processing began to melt and "burn" away. The dramatic peaking of emission rates of the semivolatile elements occurred during this period. The emission characteristics under these plenum warmup conditions are very similar to those described earlier.

\section{LECM OFF-GAS PROCESSING REQUIREMENTS}

Because of the operating characteristics of LFCMs, a contaminated gas phase waste stream is generated by the process that requires treatment before it can be released to the environment. A MOG treatment system provides this function by puliing off these hot, contaminated, steam-laden emissions and decontaminating them. As discussed previous7y, LFCM process exhaust consists primarily of steam, volatilized effluent, and suspended aerosols. Since most waste components that require long-term environmental isolation are lost to the off-gas system as condensed phase matter (aerosols), LFCM process off-gas (POG) treatment systems are composed primarity of aerosol emission abatement devices and ancill tary support equipment.

Like other high-temperature combustion processes, vitrification produces two distinct and independent classes of aerosol effluent: entrained and semivolatile condensed matter (see previous section for details). Because many radioactive semivolatiles such as ${ }^{137} \mathrm{Cs}$ form condensation aerosols which are primarily of submicron size, high-efficiency aerosol removal devices are required components of LFCM processing systems. However, these devices are not, in general, compatible with high off-gas aerosol and steam loadings or with high melter exhaust temperatures; consequent7y, aqueous quench scrubbers are universally used to precondition the process exhaust by cooling the exhaust stream, condensing the steam, and removing large-diameter $(>1 \mu \mathrm{m})$ entrained debris. Because entrained matter can also present an off-gas line 
blockage problem, off-gas quenchers are usually close coupled to the melter source to minimize or at least localize this problem.

In general, a third stage of off-gas treatment would be required if one or more radioactive waste components formed a gaseous effluent that was thermodynamically stable and was little affected by the aqueous quench scrubbing stage. However, radionuclides such as these $\left({ }^{3} \mathrm{H},{ }^{14} \mathrm{C}\right.$, and $\left.{ }^{129} \mathrm{I}\right)$ are usually not significant components (curie basis) of HLLH. Consequently, the off-gas technologies used to support these U.S. vitrification plants do not provide special removal capabilities for these isotopes.

The process off-gas system used in support of the DWPF, the WVDP, and the HWVP are illustrated in Figures 10 through 12, respectively. These off-gas technologies are functionaliy equivalent, although the actual equipment comprising these systems varies somewhat. Both HWVP and WVDP employ a submerged-bed scrubber (SBS) and high-efficiency mist el iminator (HEME) as the primary quench scrubber and high-efficiency aerosol removal device, respectively. The DWPF, on the other hand, utilizes an ejector venturi as its quench scrubber and employs a tandem steam-atomized scrubber in addition to a HEME to remove submicron aerosols. A17 MOG systems use a dual in-line high-efficiency particulate air (HEPA) filter assembiy as a final removal stage for off-gas submicrons before the melter exhaust stream leaves the processing cell. A final stage of high-efficiency filtration occurs before process stream gases are released to the stack. This is accomplished with a sand filter at the DWPF and at the HWVP and by a tandem HEPA filter assembly at the WVDP.

Other differences between these POG systems that have no impact on routine system performance are the following:

- The DHPF MOG system design has a fully redundant back-up system.

- The HWVP uses the vessel vent system as a MOG back-up system.

- The HVDP has no MOG back-up system.

- The HVDP uses the MOG system as part of its vessel vent system.

In order to compare the effluent emission abatement capabilities of the three off-gas technologies, the performance expectations of individual off-gas 


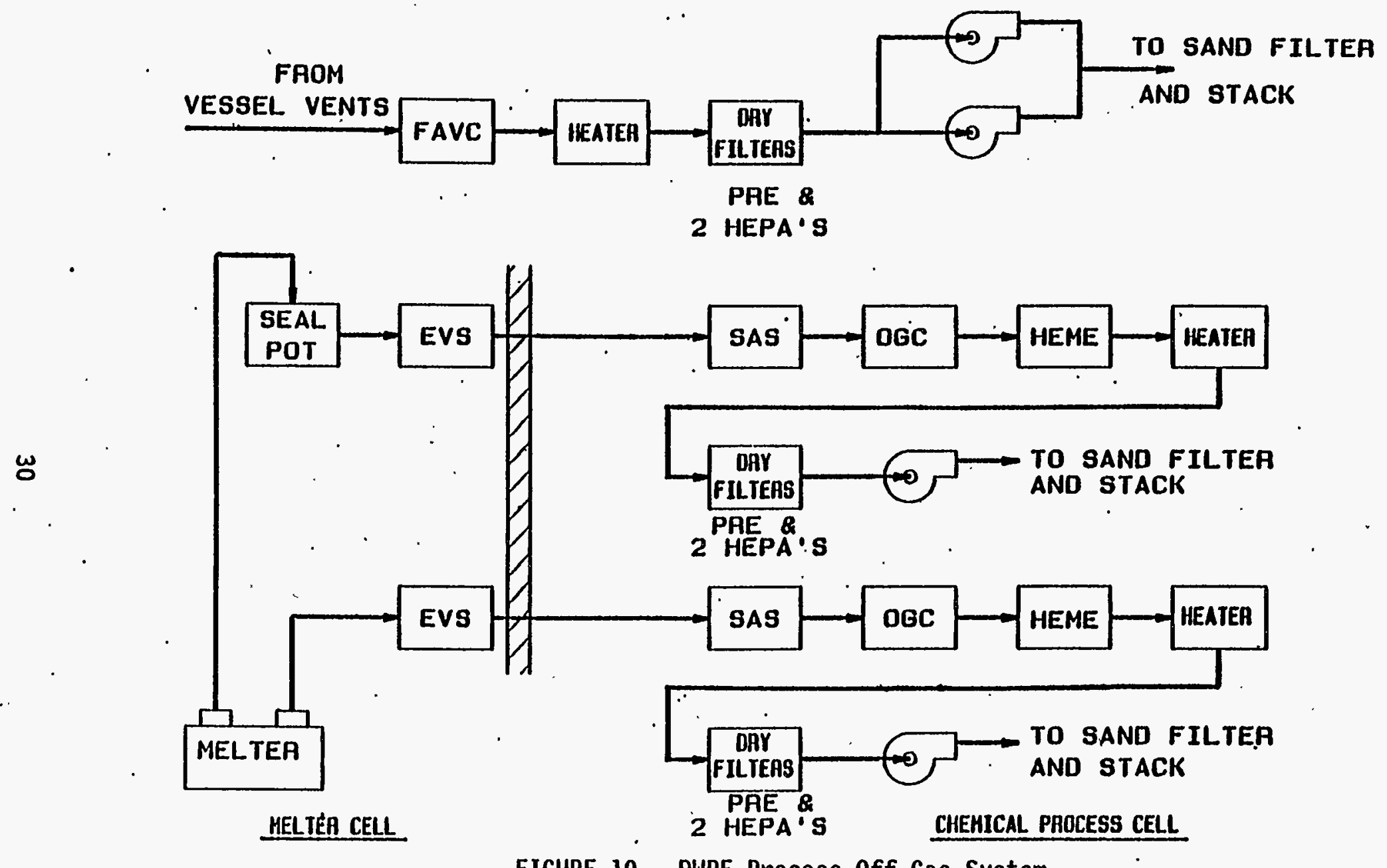

FIGURE 10. DWPF Prọcess Off-Gas System 


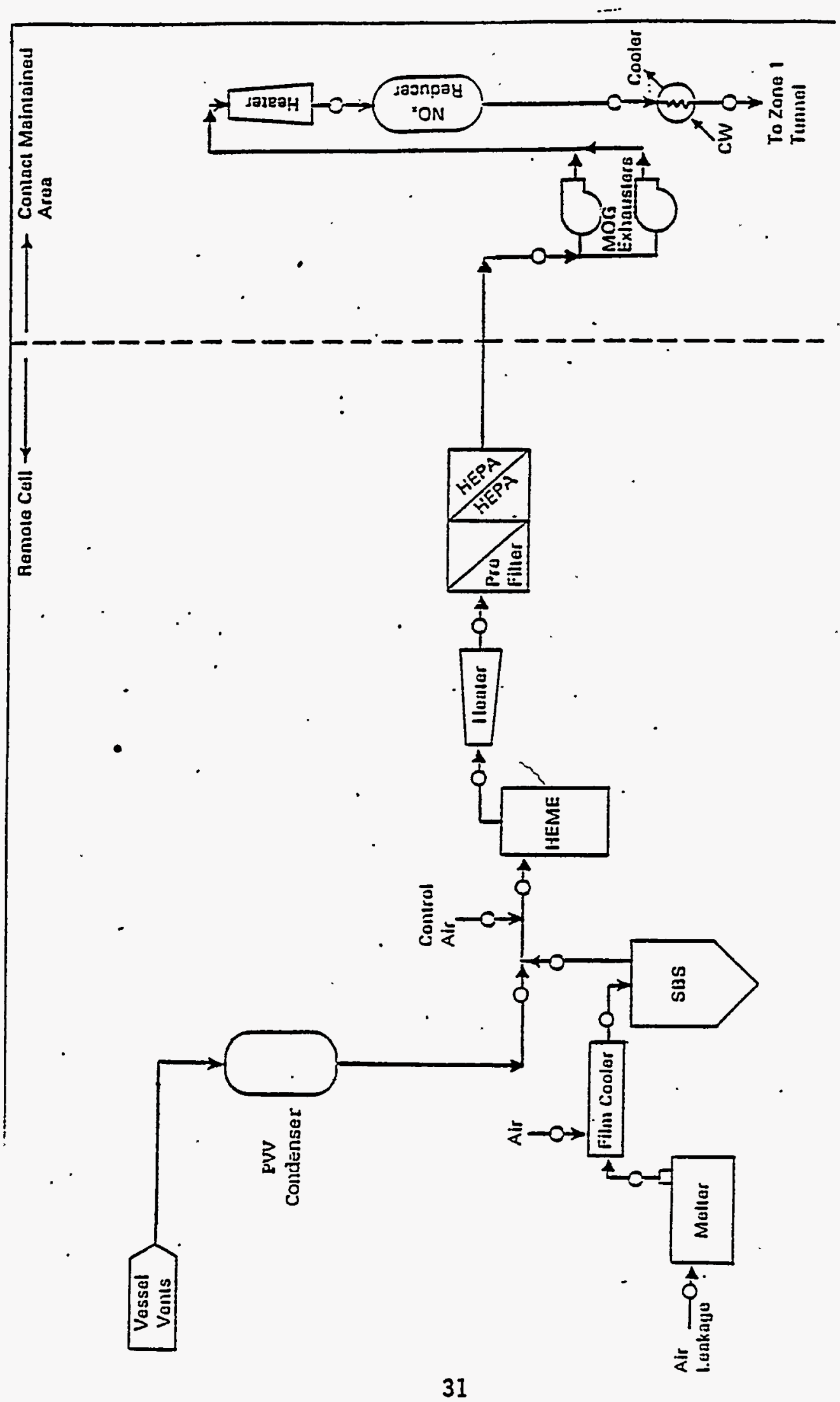

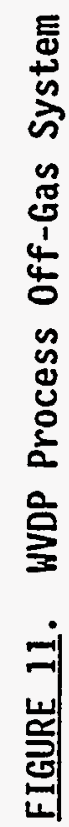




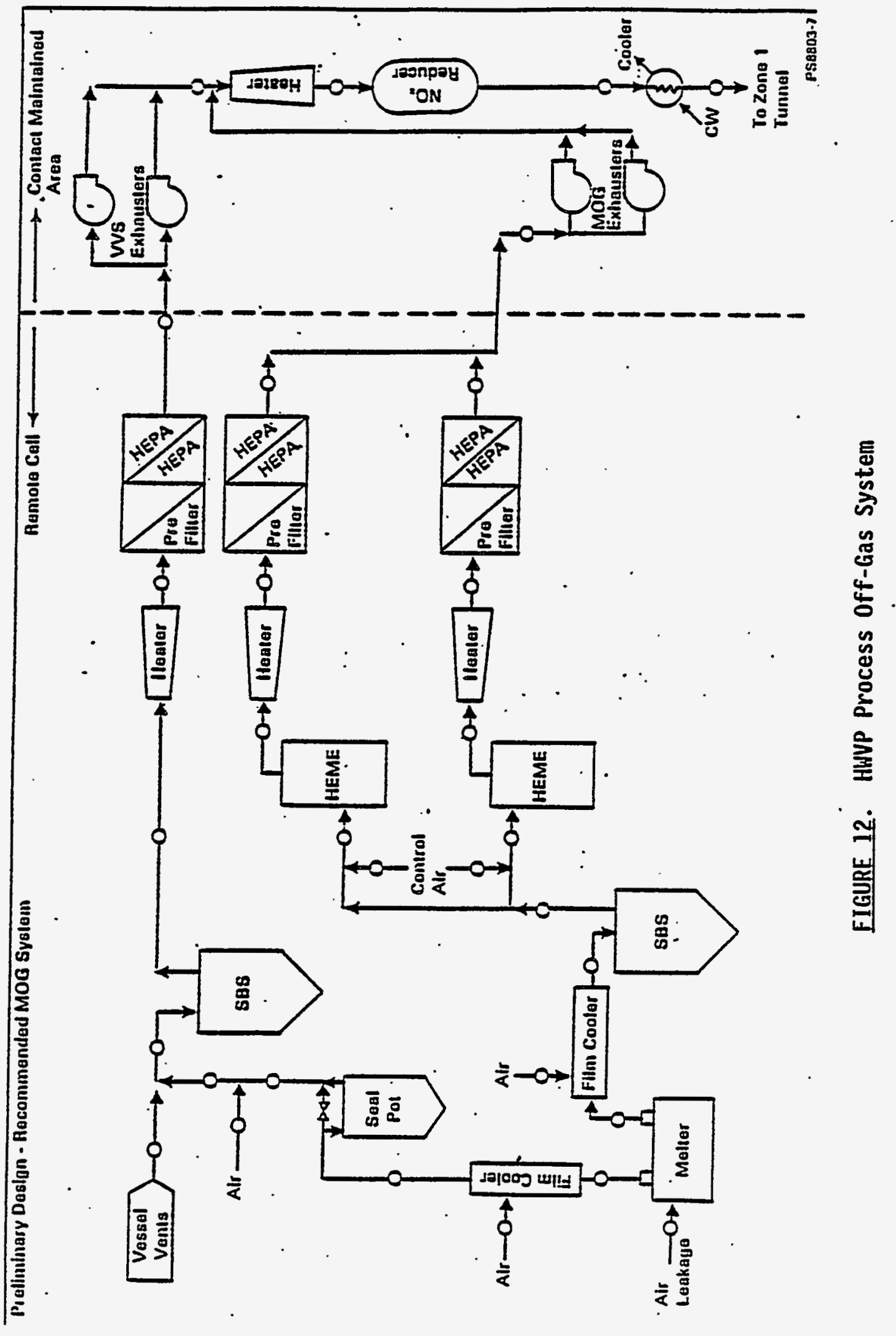


system devices need to be established. Off-gas equipment operating characteristics and performance data are discussed in the following sections.

\section{Primary Scrubbers}

As discussed above, two different types of quench scrubbers are used in off-gas system designs supporting U.S. vitrification plants. Of the three off-gas technologies being considered here, only the DWPF design calls for an ejector-venturi scrubber (also called a jet or eductor scrubber). This scrubber has been used for many types of industrial emissions since the early 1960s. As shown in Figure 13, the device utilizes a high-pressure spray nozzle that atomizes liquid to particle-collecting droplets. These units have a large water consumption compared to other scrubbers--50 to $100 \mathrm{gal}$ per $1000 \mathrm{ft}^{3}$ of gas handled. The liquid spray stream provides motive force for the gas; rather than a pressure drop, a draft of several inches water can be developed. High relative velocity between liquid droplets and gas aids in separating the two streams (Calvert et al. 1972). Harris (1966) describes the three major activities of the ejector-venturi: 1) impaction of the fume

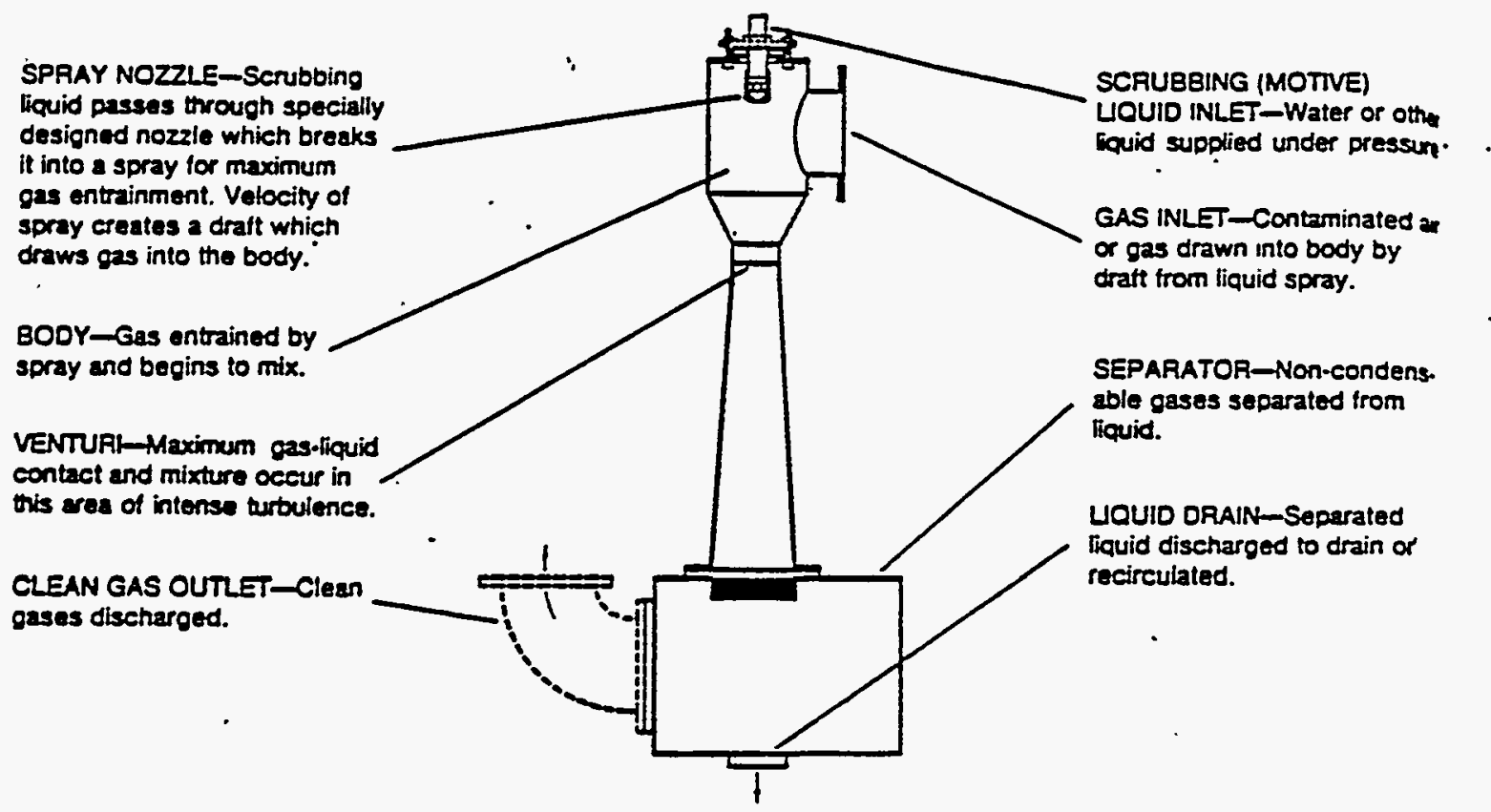

FIGURE 13. Principle of Operation of Ejector-Venturi Scrubber, from Ametek Brochure 
particle by a larger, faster-moving water droplet, 2) retention or capture of. the particles by the water drop, and 3) removal or separation of the water drop containing the particle from the air or gas stream. Separation is generally accomplished with a simple gas reversal chamber.

The ejector scrubber has been selected over other scrubber types for LFCM service because it is effective for aerosols down to $1 \mu \mathrm{m}$ in size, is compact and thus requires little radioactive process cell. space, is simple to operate, has few vuinerable internal components, and because a given unit can accommodate wide variations in inilet gas volume, temperature, and composition. The major peripheral equipment for the ejector scrubber are a recirculation pump and a tank for storage of liquid.

The quench scrubber utilized in WVDP and HWVP off-gas designs is a SBS. Originally conceived as a self-cleaning aerosol scrubber for reactor containment emergency ventilation systems (Hilliard, McCormack, and Postma 1981), the SBS is a packed cylindrical bed submerged in a scrub solution vessel; gas to be cleansed enters at the bottom of the bed through a central downcomer pipe. Off-gas system vacuum and gas buoyancy drives liquid recirculation as the gas is pulled upward via the POG system blowers. This recirculating fluid transfers heat from the hot melter-emitted gas and provides for gas scrubbing. and cleaning of the bed. These processes are shown in the schematic of Figure 14: As Tiquid and gas make concurrent contact in the bed, the liquid is heated. The outer portion of the vessel is fitted with cooling coils to remove this heat. Because of this internal recirculation, no external pump is needed, a significant advantage because scrub liquid is abrasive and usual7y corrosive. Since the quenching and scrubbing functions of the SBS do. not require active process support, this device is inherently more reliable and predictable than the ejector venturi scrubber (EVS) which does. However, the price paid for passivity is a high pressure drop through the bed, which is set by the submergence of the inlet gas pipe--nominaliy 38 inches.

The following two subsections discuss and compare the emission abatement performance characteristics of these two devices, the EVS and the SBS, as they relate to aerosol and gaseous effluent collection. 


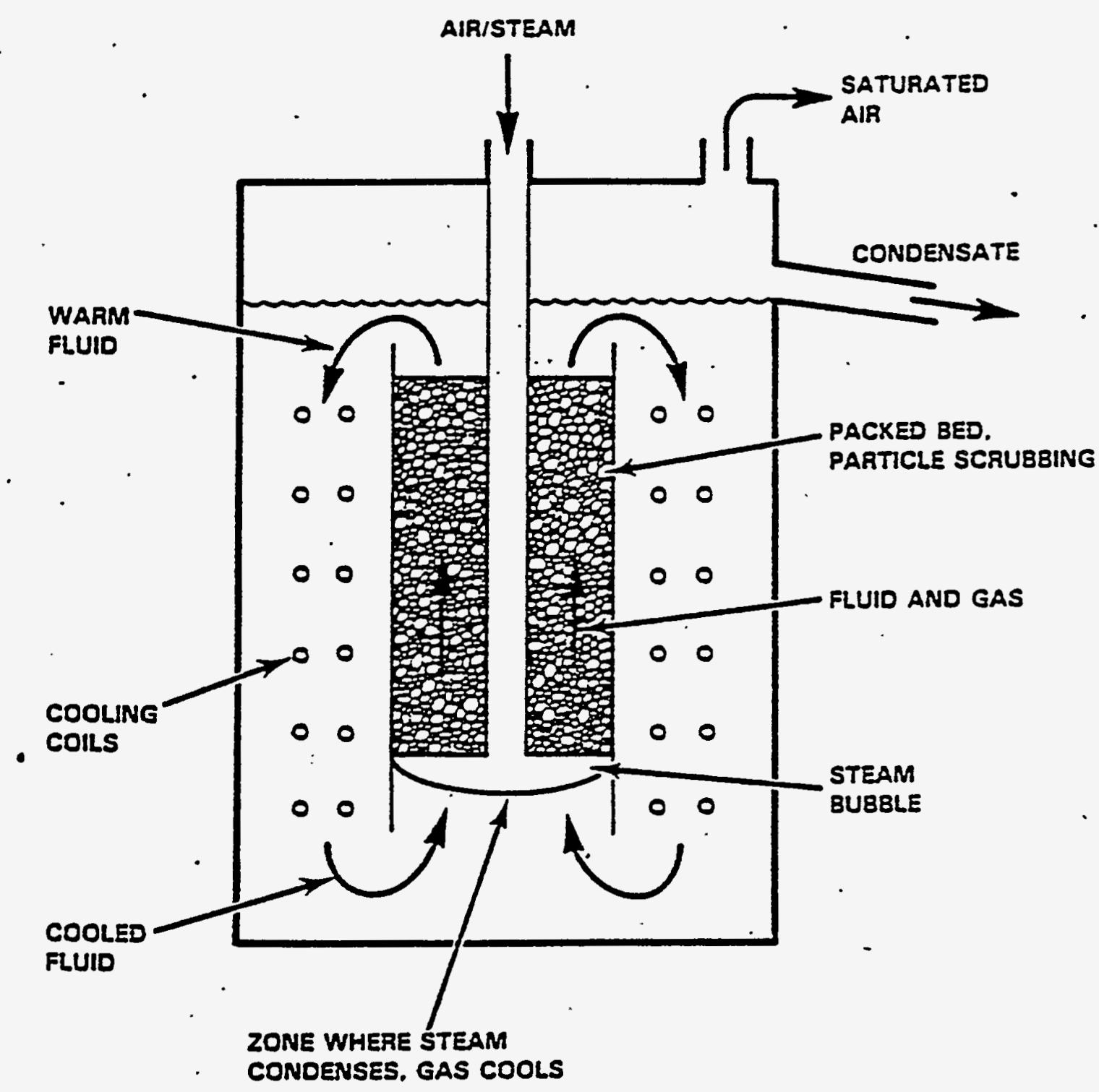

FIGURE 14. Principle of Operation of Submerged Bed Scrubber

\section{Aerosol Collection Performance of Primary Scrubbers}

By design, quench scrubbers are low-efficiency devices capable of removing only large-diameter $(>1 \mu \mathrm{m})$ airborne particulate matter. A typical particulate removal performance curve of an EVS obtained from manufacturer. data sheets is reproduced as Figure 15. Since scrubbing efficiency is a7so dependent on scrubbing fluid pressure, grain loading, and the composition and density of the inlet gas, the ordinate scale of this performance curve will 


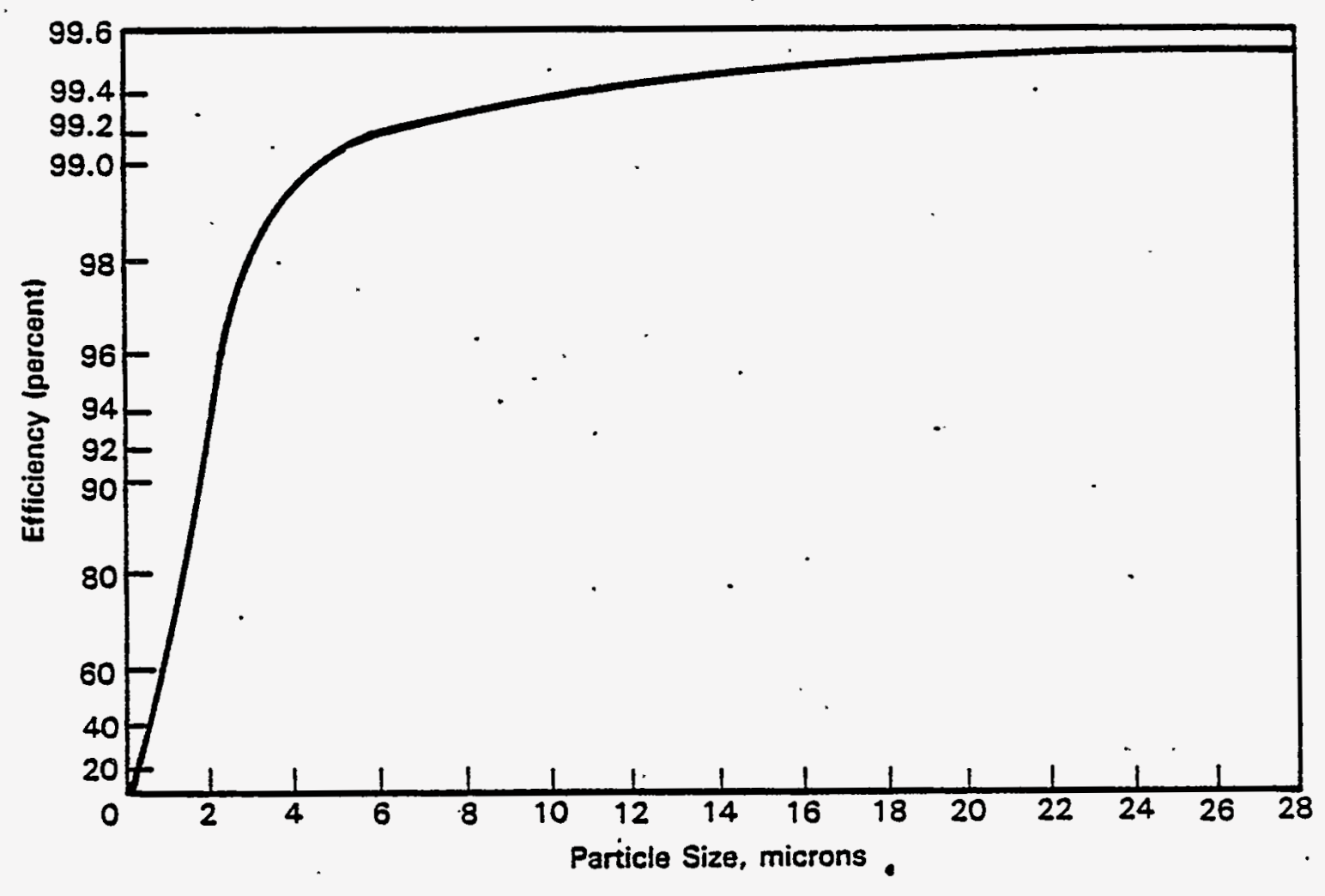

EIGURE 15. Typical Particulate Removal Efficiencies for Type 7014 Ejector Venturi Scrubbers (Ametek Catalog, Technical Supplement 7S)

vary depending on conditions; however, the shape of the curve wi11 not. As a result, this type of scrubber is exceedingly useful for el iminating largediameter effluent entrained in the process off-gas stream. Moreover, since this type of scrubber can accommodate wide variations in inlet gas volume, temperature, and composition, it is also well suited for absorbing the impacts of processing upsets, which act to significantly increase off-gas aerosol and steam loadings. Because of the nature of the EVS performance curve and the size distribution characteristics of entrained matter, process upsets should not, in general, significantiy affect downstream processing conditions.

The .SBS quench scrubber is not a commercial product and as such its performance cannot be easily generalized. However, the original design of this device, which has been adapted to LFCM applications, has been tested and documented. Using a polydispersed $\mathrm{Na}_{2} \mathrm{O}$ aerosol having a mass median 
diameter of $3 \mu \mathrm{m},-$ Owen and Postma (1981) recorded SBS scrubbing efficiencies in excess of 99\%. Reucker and Scott (1987) subsequent7y used submicron aerosols to evaluate the influence of SBS operating parameters upon removal efficiency. One of the more important relationships developed in this study was the dependence of aerosol DF (influent mass/effluent mass) upon superficial face velocity, which is reproduced in Figure 16. Taken together, these data suggest that the overa11 performance characteristics of the SBS quench scrubber are quite similar to those of the EVS, although SBS performance may be slightly higher for submicron matter.

Experimental MOG performance data have indeed shown the two quench scrubbers to behave comparably under typical LFCM operating conditions, as evidenced by comparing the size distribution characteristics of quench scrubber influent aerosols (Table 2) with characteristic effluent aerosols (Table 8) penetrating these devices. Given the demonstrated equivalence of

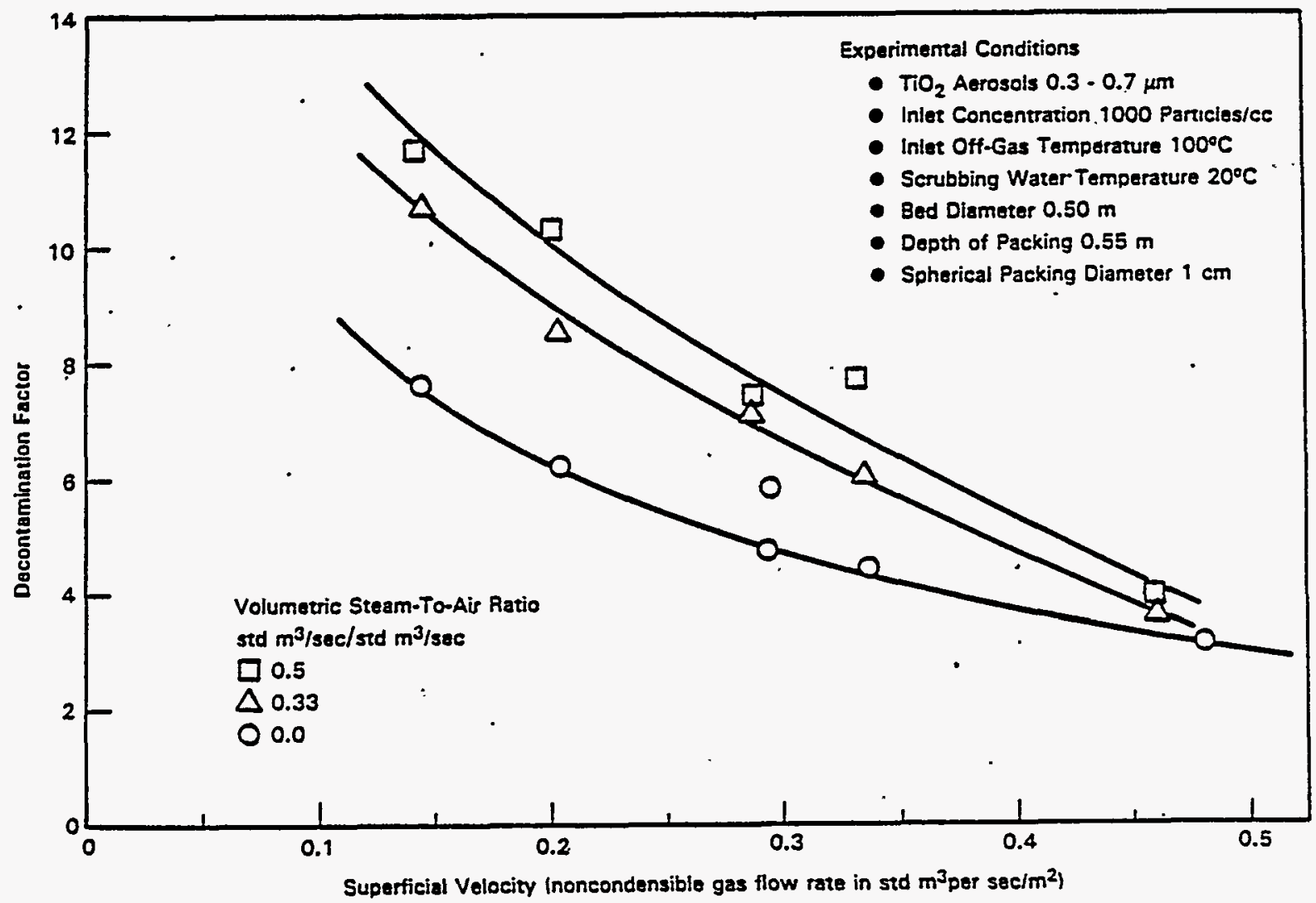

FIGURE 16. Influence of Steam on SBS Performance $\left(\mathrm{TiO}_{2}\right)$ (Ruecker 1987) 
TABLE 8. Aerosol Characteristics. Exiting Quench Scrubbers

\begin{tabular}{|c|c|c|c|c|c|c|c|}
\hline & & Wt\% of & ss & ected & Size & sificat & \\
\hline PNL Test & Device & $24.2 \mathrm{gm}$ & $2.7 \mathrm{~km}$ & $1.5 \mathrm{~km}$ & $\underline{0.86 \mathrm{~mm}}$ & $0.57 \mathrm{~mm}$ & $\leq 0.35 \mathrm{~mm}$ \\
\hline & SBS & 0.02 & 0.09 & 0.53 & 4.8 & 6.8 & 87.7 \\
\hline Cr & EVS & 0 & 0 & 1.2 & 5.7 & 14.9 & 78.2 \\
\hline
\end{tabular}

LFCH quench scrubbers and their operational characteristics, quench scrubber elemental DFs (influent concentration/effluent concentration) should, in general, be direct measures of the mass medium diameter of the aerosols responsible for individual feed component losses. Specifically, low DFs would be expected for feed components, like cesium, which are volatilized and quickly converted, by reaction and/or condensation, to predominantly submicron aerosols. On. the other hand much higher DFs should occur for nonvolatiles like strontium, whose off-gas system losses are due primarily to gross feed entrainment. Such is indeed the case for both the EVS and SBS, as the results in Table 9 clearly show. The variability of the overail (mass). DFs listed in this table reflects the relative importance of entrainment and volatilization loss mechanisms. When most of the aerosol mass leaving a melter is associated with submicron matter as in the PSCM-9 and PSCM-20 tests (see Table 2), low overall scrubber DFs result: Conversely, high mass

FABLE 9. Volatile and Nonvolatile Quench Scrubber DFs

\begin{tabular}{|c|c|c|c|c|}
\hline \multirow{2}{*}{ PNL Test } & \multirow{2}{*}{$\begin{array}{c}\text { Scrubber } \\
\text { Type }\end{array}$} & \multicolumn{3}{|c|}{ Quench Scrubber DF } \\
\hline & & Cs & $S r$ & Mass \\
\hline PSCM-8 & EVS & 11 & 300 & 54 \\
\hline PSCM-9 & EVS & 7.1 & $>900$ & 6 \\
\hline PSCM-15 & SBS & 5.8 & 9800 & 32 \\
\hline PSCM-16 & SBS & 9.5 & 1300 & 28 \\
\hline PSCM-17 & EVS. & 5.8 & 360 & 36 \\
\hline PSCM-19 & SBS & 6.0 & 1300 & 29 \\
\hline PSCM-20 & EVS & 1.7 & 44 & 2 \\
\hline PSCM-21 & SBS & 1.5 & 1600 & 18 \\
\hline PSCM-22 & EVS & 1.4 & 260 & 5 \\
\hline PSCM-23 & SBS & 3.3 & 370 & 7 \\
\hline
\end{tabular}


scrubber DFs result when melter tests are characterized by high entrainment losses as in PSCM-8 and PSCM-15 (Table 2). Since feed entrainment does not significantiy affect the melter cesium effluent source, the quench scrubber cesium DFs tend to be less variable from test to test than are the results obtained from nonvolatile or overall mass effluent data. However, the concentration and mass median diameter of the semivolatile efficuent aerosols, like the nonvolatiles, do vary from test to test, which results in some quench scrubber performance variability. These facts are demonstrated by both the EVS and SBS DF results in Table 9. Since the average off-gas performances of these two scrubbers are essentially indistinguishable in this set of unrelated LFCM tests, they will be considered equivalent and the effects of various melter and off-gas operating conditions (upsets, flow rate and concentration) upon scrubber performance wi11 be discussed below in a strictly generic sense.

Process Upsets. Processing instability can result from various operations or conditions, such as overfeeding, glass reboil or foaming, feed rate variations and/or interruptions, and cold cap bridging. The effects of these upsets, as discussed previous7y, are to increase melter entrainment. 1osses, which quench scrubbers should be fully capable of handling. Table 10 presents melter and quench scrubber (SBS) performance data taken before (5/30$6 / 3)$, during (6/3-6/7), and after (6/7-6/9) a processing upset initiated by a feed compositional change. The diametrically opposed response of the scrubber to the changes in melter mass DF clearly demonstrates the scrubber's ability to absorb the resultant increase in off-gas aerosol loading. A7though the melter upset was significant and prolonged, the cesium DFs of the melter and scrubber did not vary significantly, nor did the variability of these DFs correlate with the process upset event in accordance with expectations. Consequently, the conditions downstream of the quench scrubber did not vary significantly in spite of a $10 \mathrm{X}$ increase in melter aerosol emission rate.

Off-Gas Flow Rate and Steam Loading. The PNL melter off-gas processing system has supported LFCM testing with and without the use of a film cooler (Scott, Goles, and Peters 1985). When not employed, the unquenched off-gas system flow is composed of melter-generated gases (mostiy steam) and air 
TABLE 10. Meiter and Quench Scrubber Responses to a Processing Upset (a)

\begin{tabular}{|c|c|c|c|c|c|c|}
\hline \multirow[b]{3}{*}{ Day } & \multicolumn{4}{|c|}{ DF } & \multirow{2}{*}{\multicolumn{2}{|c|}{ Overal1 }} \\
\hline & & ter & Quenc & Scrubber & & \\
\hline & Mass & Cesium & Mass & Cesium & Mass & Cesium \\
\hline $5 / 30$ & 150 & 30 & 28 & 1.8 & 4200 & 54 \\
\hline $6 / 1$ & 270 & 29 & 12 & 1 & 3200 & 29 \\
\hline $6 / 2$ & 250 & 55 & 14 & 1 & 3500 & 55 \\
\hline $6 / 3$ & 160 & 34 & 20 & 1.9 & 3200 & 64 \\
\hline $6 / 4$ & 24 & 34 & 100 & 1.3 & 2400 & 44 \\
\hline $6 / 6$ & 86 & 25 & 28 & 1.4 & 2400 & 35 \\
\hline $6 / 7$ & 145 & 15 & $\overline{13}$ & 1.9 & 1900 & 29 \\
\hline $6 / 8$ & 140 & 19 & 19 & 2.2 & 2600 & 42 \\
\hline $6 / 9$ & 200 & 52 & 19 & 1.2 & 3800 & 62 \\
\hline
\end{tabular}

- (a) PSCM-21 WVDP sponsored LFCM tests.

inleakage. Under these conditions, steam loadings of $75 \%$ are common. With an air-driven film cooler, the unquenched off-gas stream is so diluted that a 75\% air composition normaliy results. Consequentiy, the use of an airdriven film cooler acts to increase unquenched off-gas system flow rates while significantly reducing steam volume collapse during the quenching process. Both effects might be expected to reduce contacting and resultant scrubbing efficiency. However, no statistically significant losses in quench scrubber performance have been observed to be associated with film cooler operation. Tabie 11 compares cesium. and overall mass quench scrubber DFs obtained under both off-gas operating conditions. These data are quite comparable except for the low average cesium DF measured during PSCM-21. This low value is apparently not related to a scrubber.contacting problem, as the sodium values also listed in this table are not similarly affected; rather, a much smaller spectrum of Cs-bearing aerosols must have been produced during that test.

Scrubber Solution Composition. When the LFCM off-gas system is operated with an air-driven film cooler, melter effluents concentrate in quench scrubber solutions because of reduced steam collection efficiencies. Indeed, 
TABLE 11. Quench Scrubber Response to an Air-Driven Off-Gas Line Film Cooler

\begin{tabular}{|c|c|c|c|c|c|}
\hline \multirow[b]{3}{*}{ PNL Test } & \multirow{3}{*}{$\begin{array}{c}\text { Film } \\
\text { Cooler }\end{array}$} & \multirow{3}{*}{$\begin{array}{l}\text { Melter } \\
\text { Mass }\end{array}$} & \multicolumn{3}{|c|}{ DF } \\
\hline & & & & ench Scru & \\
\hline & & & Mass & Cesium & Sodium \\
\hline PSCM-15 & N & 240 & 32 & 6.0 & 19 \\
\hline PSCM-16 & N & 160 & 30 & 9.5 & 33 \\
\hline PSCM-19 & $Y$ & 350 & 29 & 6.0 & 23 \\
\hline PSCM-21 & $Y$ & 190 & 19 & 1.5 & 18 \\
\hline
\end{tabular}

under noncondensing conditions, the concentrations of feed components will continually increase until the scrubber solution is recycled or diluted. For soluble effluents like cesium, the implication of this concentration effect is to decrease net scrubber efficiency by increasing re-entrainment loss rates. The magnitude of this effect, of course, depends upon off-gas and scrub liquor effluent concentrations and off-gas re-entrainment rates.

Because of the turbulent operating conditions associated with the SBS, the scrubbing performance of this device could very well be limited by the re-entrainment rates of previously removed effluent matter. This technical issue was specifical7y addressed during the recent HWVP-15/PSCM-23 me7ter test (Goles 1989). Examination of the time-dependent, SBS effluent off-gas concentration data collected during that test reveals (see Figure 17) that when the melter source is turned down, as occurs for nonvolatiles during idling, the SBS effluent off-gas concentrations of these feed components also dramatically decrease. Moreover, the SBS exhaust concentrations of the semivolatiles, whose melter emissions persist but decrease during idling, a) so decrease in a-corresponding way with the melter source term. This is found to be true for both soluble as well as insoluble matter. Consequently the effluent matter being exhausted from the SBS is predominantly airborne material that simply and directly penetrates the device, and the contributions from re-entrainment are found to be insignificant under projected HWVP operating conditions.

The above result has also been previously demonstrated for an EVS quench scrubber during a melter test (PSCM-20) involving a liquid s7urry containing 


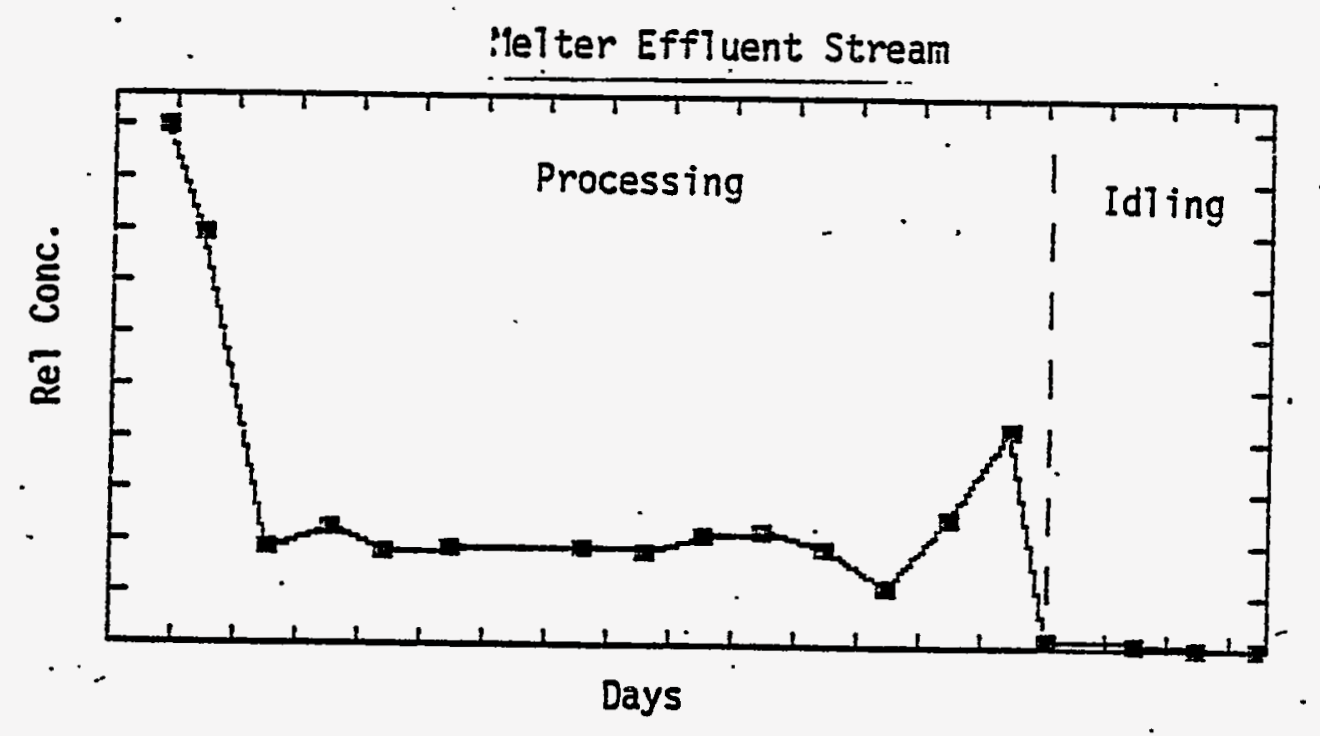

SBS Effluent Stream

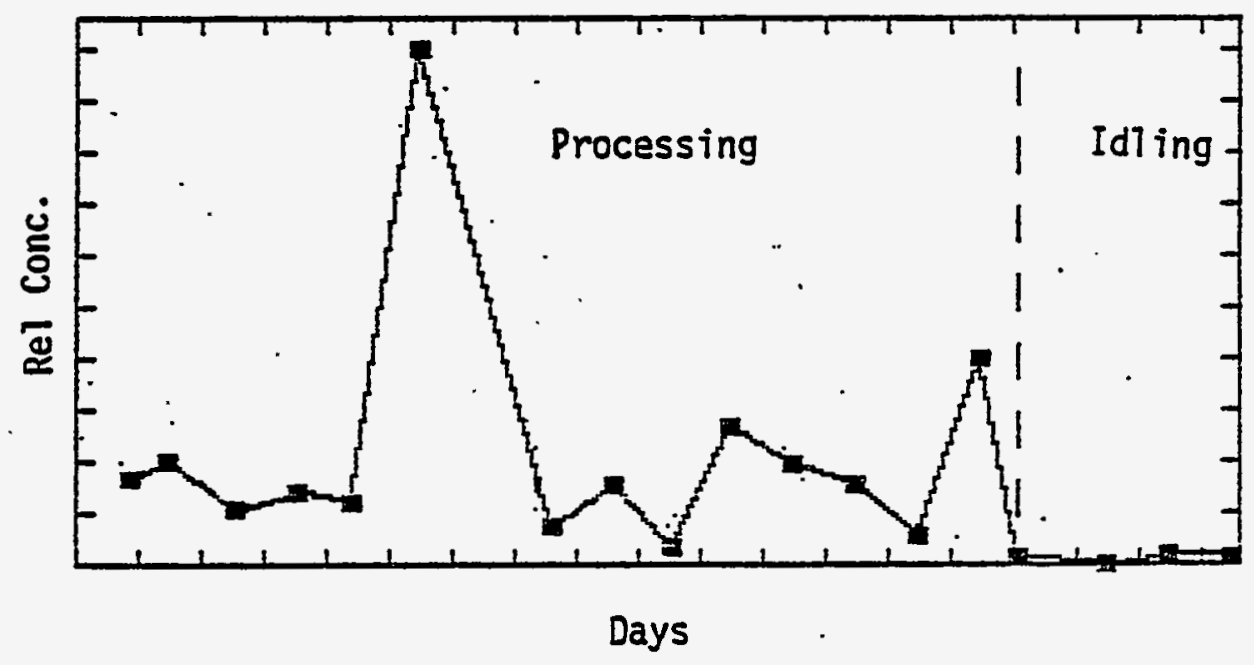

FIGURE 17. Strontium Concentrations in Melter and SBS Off-Gas Steams During Processing and Idling

high (5 wt\%) cesium content (Goles 1986). Table 12 summarizes the performance of an EVS quench scrubber measured over a continuous 20-day interval, during which time there. was a five-fold increase in semivolatile scrubbing liquor concentration. Clearly, the variability in observed quench scrubber performance for cesium does not correlate with scrub liquor concentration trends and no relationship.between cesium (semivolatile) scrubbing efficiency and re-entrainment of scrubbing liquor was. observed. 
TABLE 12. Quench Scrubber Performance as a Function of Scrub Liquor Concentration

\begin{tabular}{|c|c|c|}
\hline \multirow[b]{2}{*}{ Date } & \multicolumn{2}{|c|}{$\begin{array}{c}\text { Quench. Scrubber } \\
\text { Cesium Characteristics }\end{array}$} \\
\hline & $\begin{array}{l}\text { Liquor } \\
\text { (mg/L) }\end{array}$ & DF \\
\hline $4 / 2$ & 139 & 1.8 \\
\hline $4 / 4$ & 244 & 2.0 \\
\hline $4 / 6$ & 234 & 2.0 \\
\hline $4 / 8$ & 193 & 1.2 \\
\hline $4 / 10$ & 224 & 1.8 \\
\hline $4 / 13$ & 469 & 1.2 \\
\hline $4 / 15$ & $674^{\circ}$ & 2.2 \\
\hline $4 / 17$ & 880 & 3.0 \\
\hline
\end{tabular}

From the above results, it is abundantly clear that quench scrubbers in general are insignificant contributors to post-scrubber effluent concentrations when compared to penetrating melter emissions under the conditions of the melter tests studied. Since the SBS data were taken under projected HWVP process conditions and the EVS results represent worst-case conditions due to the 10X cesium content of the feed, the conclusions drawn should be valid for all reasonable off-gas operating conditions.

\section{Radioactive Gas Collection Performance of Primary Scrubbers}

The radioactive isotopes of particular importance with regard to LFCM gaseous emission are carbon-14 tritium (T), ruthenium-106, technetium-99, and iodine-129; the major chemical forms responsible for the gaseous emission of these elements are $\mathrm{CO}_{2}$, HTO (tritiated water), $\mathrm{RuO}_{4}, \mathrm{Tc}_{2} \mathrm{O}_{7}$, and $\mathrm{I}_{2}$, respectiveiy. Due to the physical and chemical properties of $\mathrm{CO}_{x}$ effluent, ${ }^{14} \mathrm{C}$ emission abatement is not provided by any of the LFCM off-gas systems being considered in the study. Quench scrubber control of LFCM tritium emissions, if required, is 1 imited to condensation and/or exchange processes which, if used in combination, would produce a secondary waste stream at least as large as that of the HLLH being processed. Fortunately, tritium is only a very minor component (curie basis) of aged HLLW,-and specific off-gas operating conditions to limit vitrification $\mathrm{plant}$ emissions of this isotope 
are not anticipated at any of the U.S. sites. In spite of this; significant quantities of HTO will be removed by normal condensation and disengagement processes associated with quench scrubber operations. Assuming a. $35^{\circ} \mathrm{C}$ scrub Tiquor operating temperature, a moisture-saturated, 500 SCFM off-gas flow rate, and $100 \mathrm{lb} / \mathrm{h}$ processing rate, a quench-scrubber/HEME HTO DF of 5 would be predicted. This projection was confirmed during scaled HWVP-15/PSCM-23 testing, where $80 \%$ of the process stean was recovered by an SBS.

Gaseous emission of. ruthenium and technetium can only occur under strongly oxidizing process conditions. Because reduced feeds will be used at all U.S. vitrification facilities, no significant volatilization of ruthenium and technetium isotopes will occur under normal processing conditions. On the other.hand, if the melter glass becomes strongly oxidized during prolonged periods of idling, volatilization of ruthenium and technetium could occur during the initial. stages of process start-up. Under worst-case conditions, volatile ruthenium loss rates of $-90 \%$ could occur until the reduced feed had sufficiently modified the oxidizing conditions within the melter. Fortunately, quench scrubber DFs for gaseous ruthenium are quite high due to a combination of condensation and chemical decomposition processes. No evidence for ruthenium gaseous penetration of quench scrubbers (either SBS or EVS) has been found at PNL. Using the analytical detection limit associated with gas scrubber samples generated during LFCM processing of oxidizing feed, a lower quench scrubber DF for gaseous ruthenium has been estimated to be 100 .

There are very little data concerning LFCM emission characteristics of technetium since no stable isotope of this element exits. No volatility of technetium is projected under normal HWVP processing conditions as the feed is sufficiently reduced. Whether $\mathrm{Tc}_{2} \mathrm{O}_{7}$ could be generated in a reduced feed by an oxidized glass is unknown; however, volatile technetium effluent(s) produced from highly oxidized feeds have been found to be quite penetrating at the PAMELA plant in Mol, Belgium. In any case, technetium volatility need not be a processing concern if the oxidizing conditions of both the glass and the feed are monitored and controlled. Because many of the physical and chemical properties of technetium are quite similar to those of ruthenium, LFCM off-gas behavior of technetium will also be assumed to be similar, for 
the purposes of this report; consequently, ruthenium off-gas data will be used to model technetium in the evaluations to follow.

Unlike ruthenium and technetium, gaseous evolution of the halogens is to be expected from LFCMS irrespective of feed composition; however, the processing of oxidizing feeds will strongiy promote losses of these elements. In particular, complete melter volatilization of iodine in the feed as $I_{2}$ is expected under these conditions. Although data on quench scrubber DFs for $\mathrm{I}_{2}$ are limited, the study that was conducted on an oxidizing WVDP feed (PSCM-9) suggests a negligible scrubbing efficiency (DF $\sim 1$ ) for this gaseous effluent. Fortunately, very little ${ }^{129}$ I is present in HLLW (curie basis) because waste handling practices effectively remove this element from HLLW streams.

\section{High-Efficiency Aerosol Scrubbers}

As discussed in previous sections, a large portion of melter-emitted aerosols are submicron, and those that are not are effectively removed by the off-gas quench scrubber. Consequently, post-quencher off-gas conditions require high-efficiency removal of rather high concentrations of very small ( $\leq 1 \mathrm{~mm})$ aerosols. It is generally not practical to collect these emissions solely with HEPA filters because frequent changeout of these filters would be required. As a result, other high-efficiency, low-maintenance devices have been identified and employed in vitrification off-gas system designs to effectively reduce submicron aerosol concentrations to levels that will extend the service life of the subsequent HEPA filter to at least one year. Two such devices have been employed in U.S. vitrification designs: a HydroSonic scrubber (HSS) and a high-efficiency mist eliminator (HEME). White both of these units are employed in the DWPF design, the HEME is exclusively used by the WVDP and the HWVP off-gas systems.

The HSS is an air- or steam-aspirated wet scrubber that collects aerosols using a supersonic nozzle to efficiently atomize water by injecting water into the wake of an expanding free jet (see Figure 18). A brochure (a) describes the phenomenon as follows: dirty gas is driven through a free-jet nozzle fitted with a water-injection ring where water is injected on to the

(a) From Hydro-Sonic ${ }^{\otimes}$, Lone Star Steel Company, Dallas, Texas. 


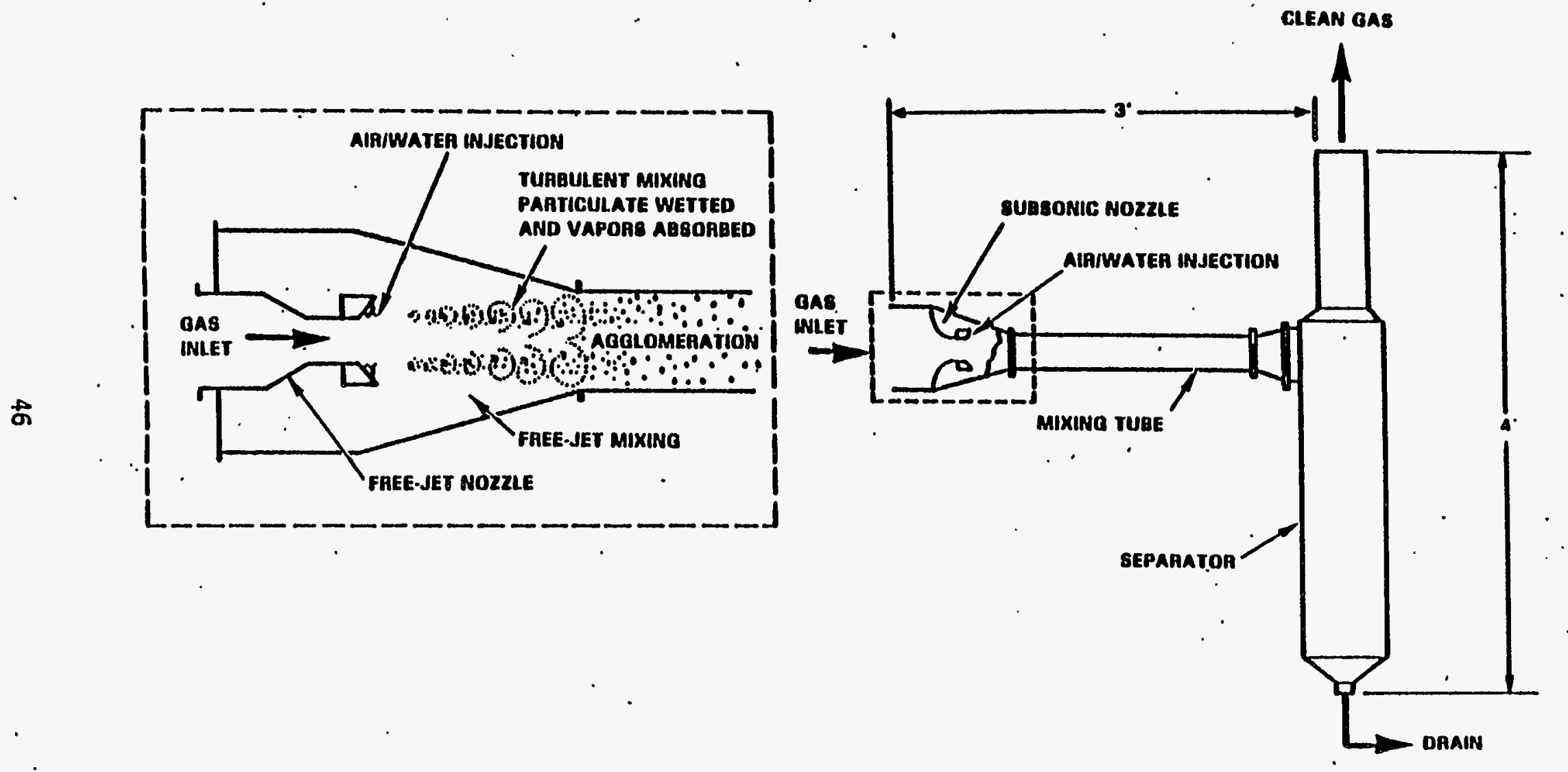

FIGURE 18. Principle of Operation of Hydro-Sonic Scrubber, Adapted from Lone Star Steel Co. Brochure 
driven gas stream. Turbulent mixing occurs as the free jet expands, causing capture of particulates in the very fine submicron sizes.

The HEME (Figure 19) is composed of a deep-bed regenerable filter configured so it can be irrigated and drained and is most effective for collection of soluble mists or fumes. HEMEs were originaliy developed by Brink (1964) for removal of acid or caustic fumes, and are available today from several domestic vendors with either fiberglass or polypropylene batting. Like HEPA filters, these devices can efficiently remove airborne submicron matter but, unlike HEPA filters, they can be operated wet to allow simultaneous removal of both liquid and solid state aerosols. Since these filters can be operated wet, a continuous water spray has often been employed to wash down and cleanse filter elements of accumulated debris, thus extending the service life of these devices. In LFCM service, much of the airborne material penetrating the off-gas quench scrubber is water soluble (alkali salts); consequent7y, continuous irrigation or batch washing operations should be quite successful in purging the filter of accumulated effluent, thereby extending effective service life of these remotely replaceable filters.

The final treatment step in all U.S. melter off-gas system designs involves HEPA filtration or its equivalent. This type of filter is universally used in nuclear air or gas cleaning systems as the final barrier between a containment area where radioactive particies could be generated and the point of environmental release--the stack. Of all the aerosol abatement devices considered up to this point, HEPA filters provide the greatest contribution to the overall system performance. Their inclusion in LFCM offgas systems ensures thorough decontamination of process-generated radioactive aerosols before stack discharge. All three off-gas system technologies being evaluated utilize a tandem HEPA filter assembly to filter the melter exhaust before it is discharged from the processing cel1, and a second filter bank-a tandem HEPA assemb7y at the HVDP, and sand filters at the DWPF and HWVP--is used as a final filtration stage before process gases are released to the environment.

The following subsections discuss experimentally derived operational performance characteristics of these high-efficiency aerosol removal devices. 


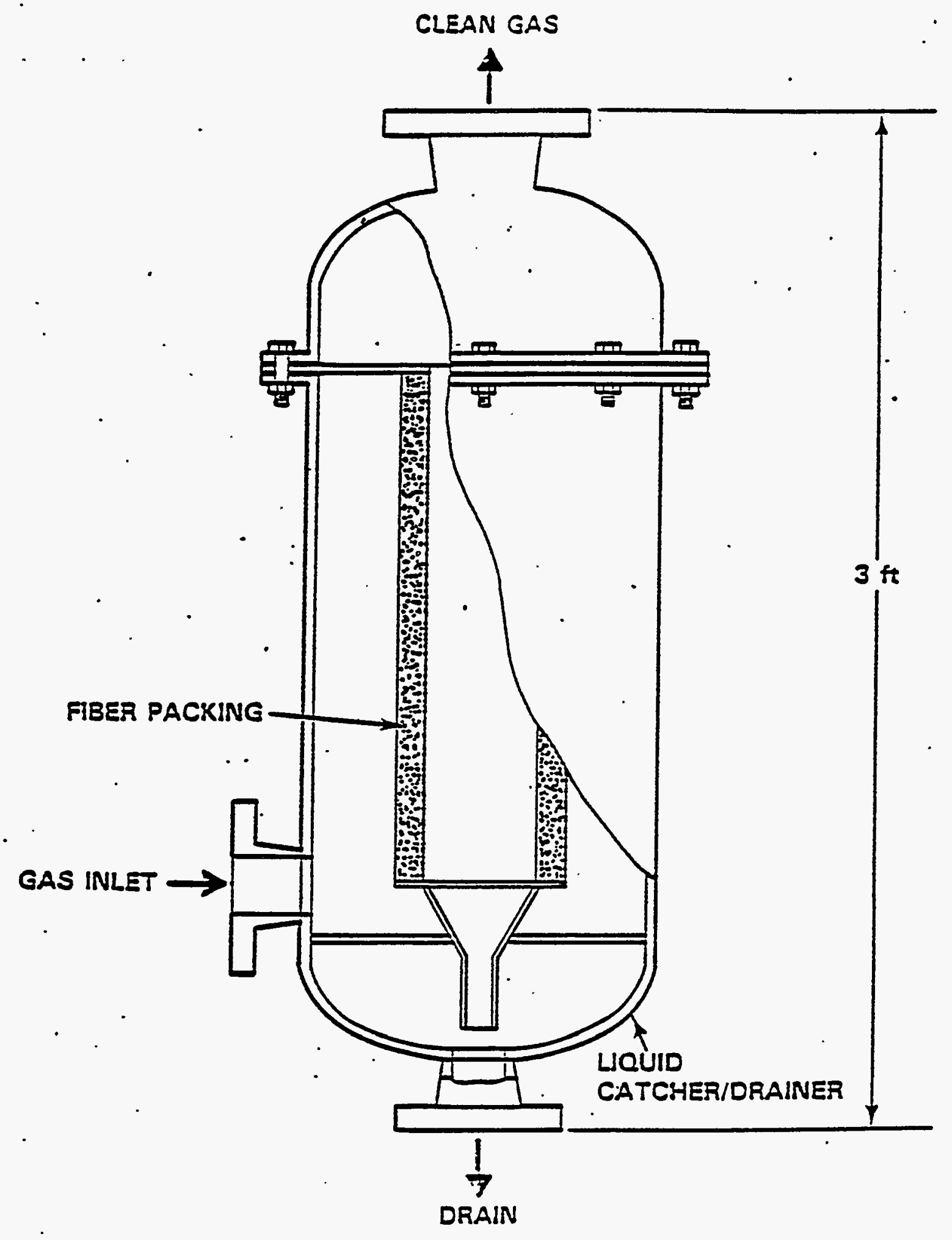

FIGURE 19. Schematic of High-Efficiency Mist Eliminator Used in PNL's PSCM Off-Gas System. 


\section{Hydro-Sonic Aerosol Scrubbing Efficiency}

The LFCM off-gas testing of HSSs has been a7most exclusively conducted by SRL (Colvin 1983), a7though PNL has had some limited experience. The SRL off-gas design provides for two cascaded hydrosonic devices directly downstream of the LFCM ejector-venturi quench scrubber. Consequentiy, most of the LFCM scrubbing performance data associated with this device involve the tandem, cascaded system that is designed to meet a. DHPF-required DF of 50 for cesium aerosols.

To properly appreciate the operating characteristics of the tandem HSS configuration, it is essential to understand the performance characteristics of a single stage unit. The most definitive performance studies of steamdriven hydrosonic scrubbers were conducted by the Southern Research Institute on open-hearth furnaces that generated challenge aerosols having a mass median diameter of $1 \mathrm{~mm}$ (McCain 1974). The results of these tests, which are documented in EPA Report 650/2-74-028, estab7ished both the overal1 mass and fractional efficiency of the HSS as a function of aerosol diameter. Figure 20 summarizes typical HSS inlet and outlet size distributions of effluent aerosols obtained during stable furnace operations and Figure 21 summarizes HSS fractional efficiencies calculated from these data together with cascade impactor measurement results. Fractional efficiency data was aiso collected during less optịmum conditions when inlet aerosol concentrations varied over a considerable range. These cascade impactor data are presented in Figure 22 under various HSS operating conditions. Overal1 DFs obtained during this study were in excess of 600 .

Wright (1983) conducted similar HSS performance tests using air rather than steam as the motive scrubbing fluid. The DF results obtained were slightly lower on the average than the furnace test data. The difference in measured performance is probably less a function of the motive scrubbing fluid used than the much lower influent concentrations involved in the airaspirated tests which used particle generators as the effluent source.

Some empirical HSS performance data have also been collected during scaled melter tests. Table 13. presents some representative scrubber data collected at SRL (Colvin 1983). In each case HSS influent conditions were 


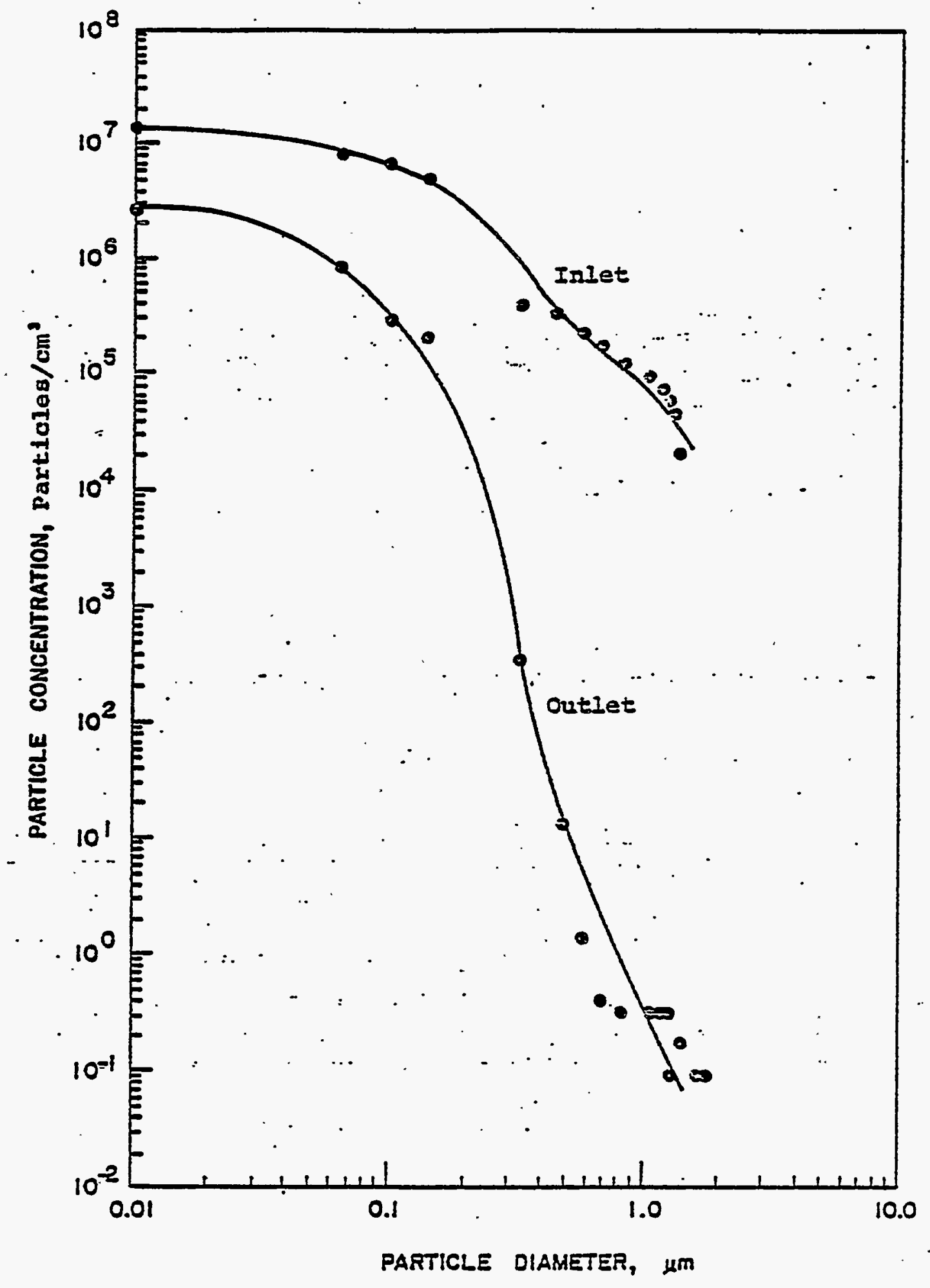

FIGURE 20. Inlet and Outlet Particle Size Distributions Measured Using Optical and Diffusional Techniques 


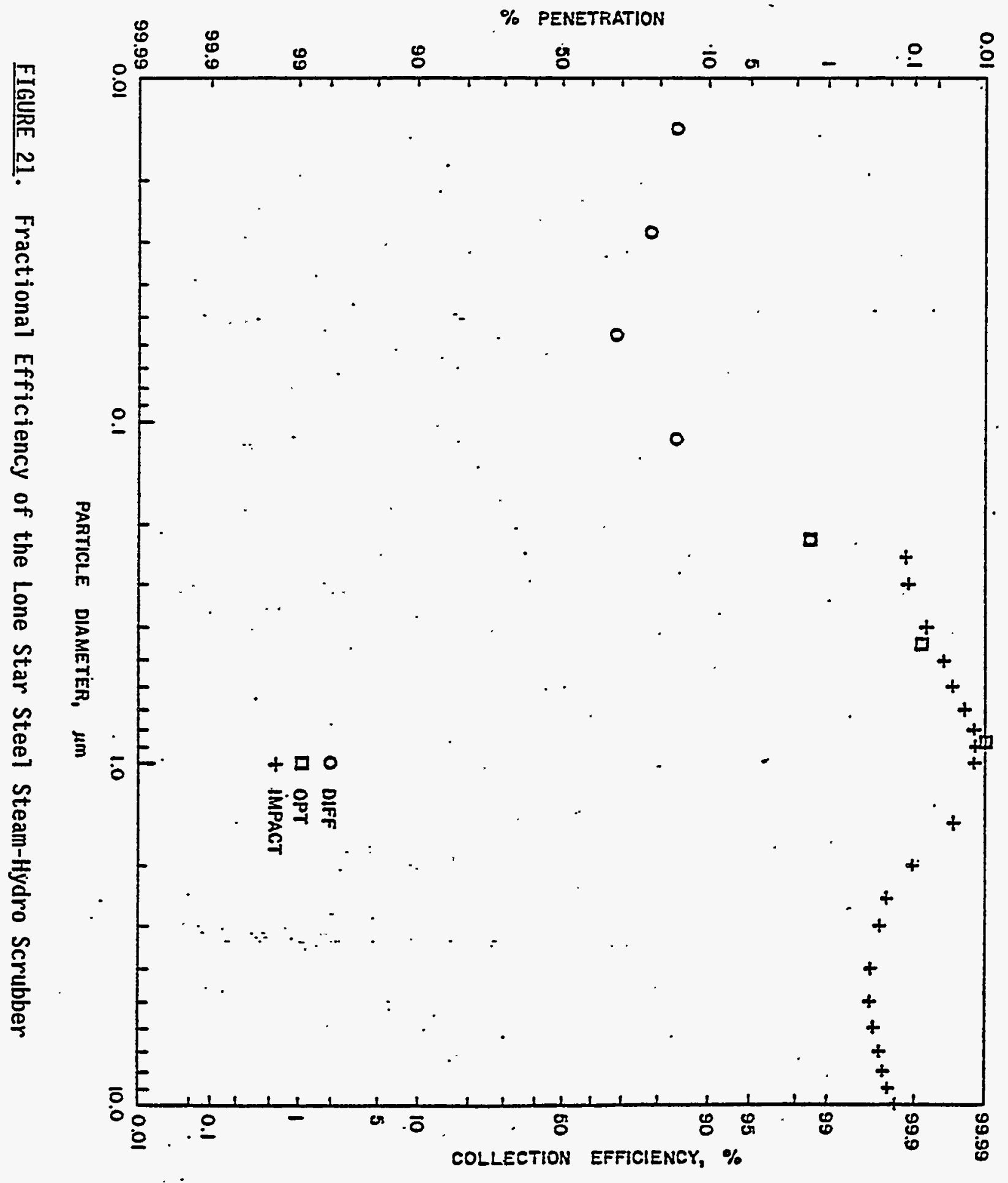




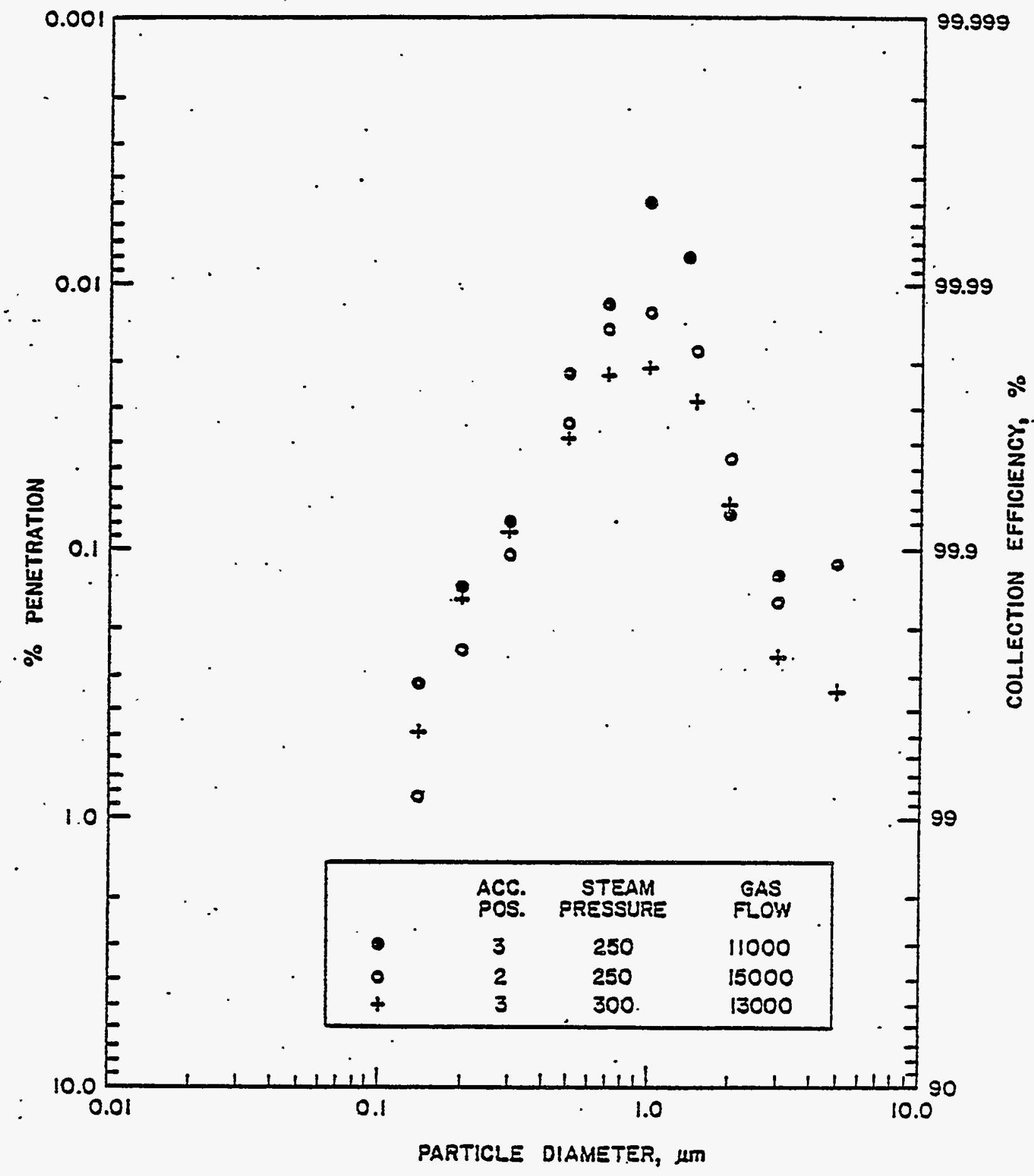

FIGURE 22. Fractional Efficiency Calculated Using Impactor Data Only 
TABLE 13. Hydro-Sonic DFs

\begin{tabular}{|c|c|c|}
\hline \multirow[b]{2}{*}{ Element } & \multicolumn{2}{|c|}{ DF } \\
\hline & Cascaded & Single \\
\hline Al & -- & -- \\
\hline B & - & -- \\
\hline $\mathrm{Ba}$ & - & -- \\
\hline $\mathrm{Ca}$ & - & $-\infty$ \\
\hline $\mathrm{Cr}$ & -- & -- \\
\hline Cs & 61 & 7.2 \\
\hline $\mathrm{Fe}$ & -- & -- \\
\hline Li & -- & -- \\
\hline $\mathrm{Mg}$ & -- & -. \\
\hline Mn & 25 & 38.6 \\
\hline $\mathrm{Na}$ & 61 & 8.9 \\
\hline$s r$ & 3 & 5.2 \\
\hline $\mathrm{Zr}$ & $=$ & $=$ \\
\hline Total & 47 & 9.0 \\
\hline
\end{tabular}

-- denotes data below detection Timit.

established by quench scrubber modifications to a processing melter source. The single stage data indicate that the mass median diameter of alkali. element containing aerosols is quite smal1, $\times 0.3 \mu \mathrm{M}$; furthermore, by comparing the single- and dual-stage alkali element data it appears that efficiency of . the first scrubbing stage does not impair or degrade the performance of the second cascaded unit. This observation is consistent with the HSS operating principles which act to modify the influent aerosol size distribution to affect removal. Since the growth and removal of influent aerosols is a statistical phenomenon, the HSS cannot act to screen out aerosols on the basis of their initial aerodynamic diameters; consequent7y, for sub-micron aerosols, the overall DF of a dual, cascaded device should be the square of that of an.individual unit, which is approximately what is observed. 
The data presented above suggest that Hydro-Sonic scrubbers are we11 suited for process control of submicron aerosols generated by LFCMs. The devices are not passive but require little more than stean and/or compressedair service.

\section{HEME Aerosol Scrubbing Efficiency}

High-efficiency mist eliminators are currently being tested as deep-bed, high-efficiency washable filters in LFCM off-gas processing systems. The main virtues of employing HEMEs for this purpose are that they are passive, renewable, and highly efficient. The fractional collection efficiencies for various high-efficiency aerosol scrubbing devices are graphicaliy displayed in Figure 23 as a function of aerosol aerodynamic diameter. The HEME is warranted by the manufacturer to be $299.5 \%$ for aerosols $\leq 3 \mu \mathrm{m}$ and nominally $100 \%$ for al1 others. Because HEME sub-micron performance is limited by diffusional capture processes, collection efficiency increases with decreasing flow rate; consequently, this device is characterized by an unlimited turndown capacity.

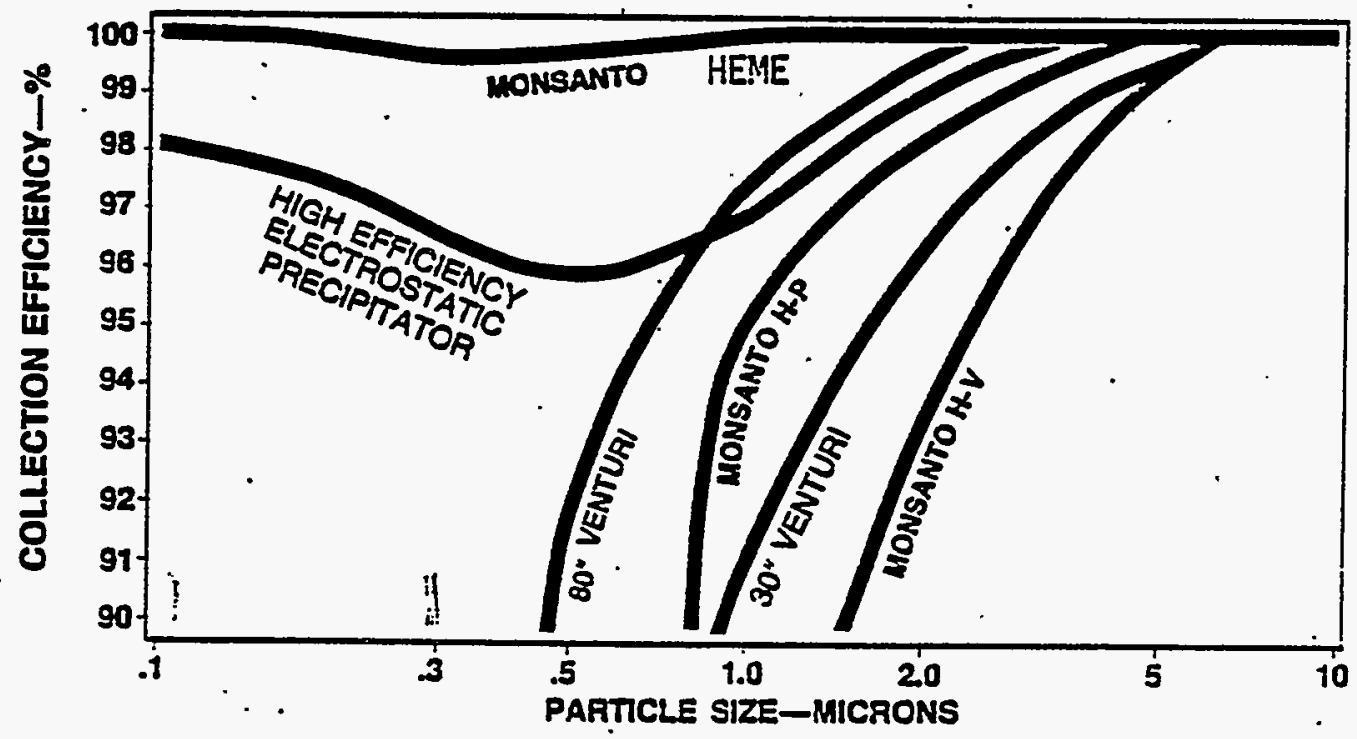

FIGURE 23. Collector Efficiency Comparisons of Various Aerosol Scrubbers by Particle Size (Monsanto Catalog IC/EC-708) 
The manufacture's data displayed in Figure 23 assume relatively high influent concentrations, which are more representative of HWVP and HVDP offgas conditions than those produced by the DWPF off-gas system configuration. Specifical7y, HEME manufacturer's performance guarantees are contingent upon HEME exhaust loadings being greater than $0.2 \mathrm{mg} /$ ACFM, which is significantly greater than normal aerosol concentration in any of the off-gas technologies being considered here. Nevertheless, very high aerosol removal efficiencies have been recorded by all candidate LFCM off-gas technologies.

Experimental HEME performance characteristics were evaluated during a recent 90-day cold, scaled SRP melter test. During that test, various highefficiency aerosol removal devices were tested upstream of the HEME, but in all cases semivolatile DFs $>100$ were observed (Colvin 1983). The HEME DFs were also observed to increase when the efficiency of the upstream device decreased. Since the concentration and mass median diameter of HEME influent aerosols will be significantly smaller in the DWPF design than for the WVDP and the HWVP (due to the presence of the tandem HSSs), the above observation suggests that significantly greater HEME DFs should be achieved by the later two off-gas systems. This was indeed found to be the case during a recent HWVP melter test (PSCM-23), where both mass and cesium DFs $>400$ were routinely observed. Similar results have been recorded at the PAMELA Facility at Mol, Belgium, where the spectrum of HEME influent aerosols is only. modified by low-efficiency scrubbing stages.

Cascade impactors were used during the PSCM-23 test to estab7ish the manner in which HEMEs interact with the spectrum of influent aerosols. The results of these studies are graphically illustrated in Figure 24, which displays SBCS and HEME effluent (white) deposits on successive cascade impactor collection stages. In a71 cases deposit masses increased with decreasing stage collection diameters. These data reconfirm the previously mentioned fact that the SBS quench scrubber efficiently removes all particles with aerodynamic diameters $\geq 1 \mu \mathrm{m}$; furthermore, the data graphically i17ustrate that the HEME significantly reduces both the concentration and the mass median diameter of this distribution in fult accordance with design expectations. 


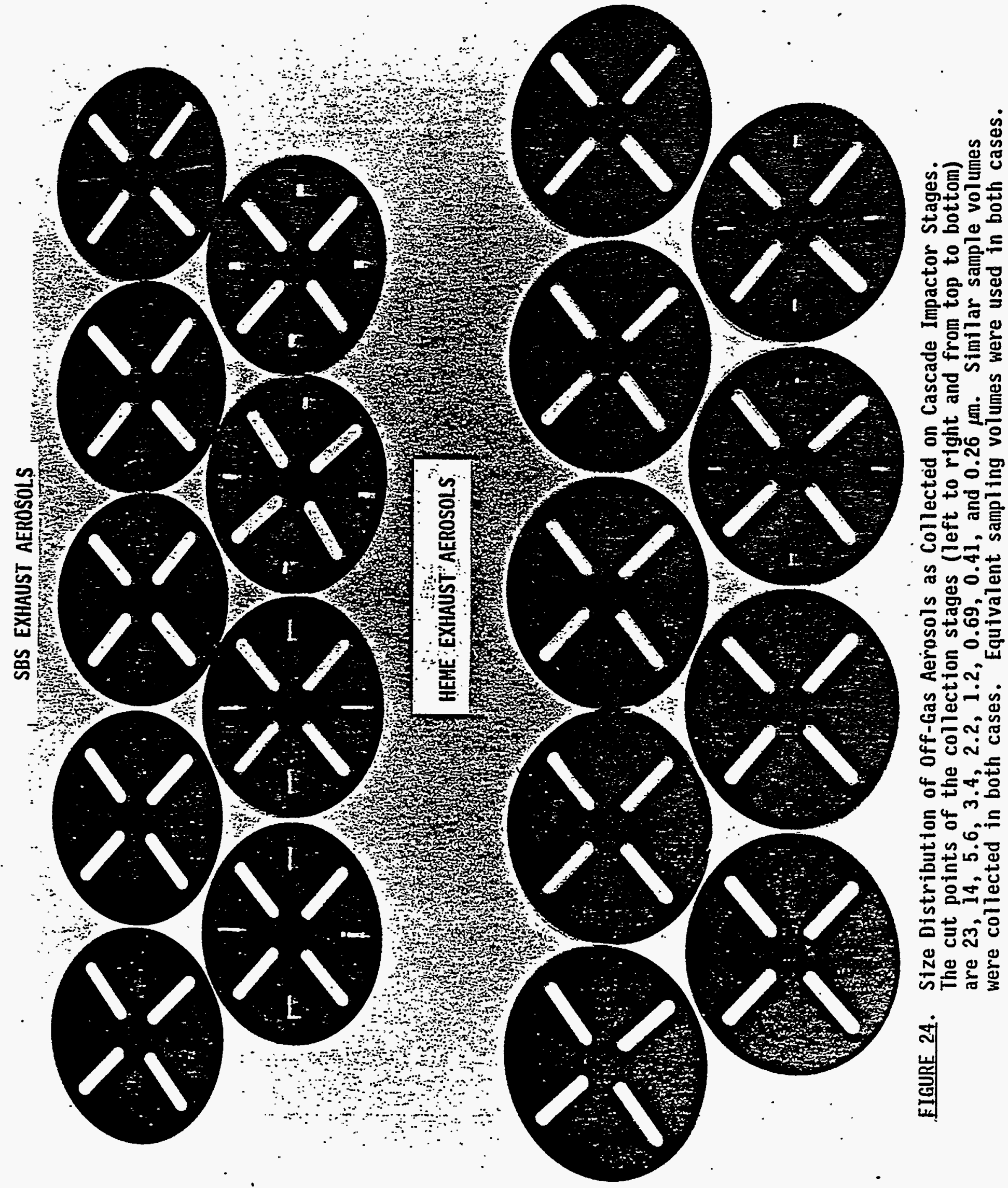


A HEME water spray whose rate is tied to noncondensible off-gas flow at nominally $0.5 \mathrm{mg} / \mathrm{ACFM}$ is used by the DWPF to continuously purge the HEME filter element of collected aerosol effluent. This operational mode is designed solely to increase service life of the filter element while eliminating or at least minimizing batch washing operations that would otherwise interrupt processing. Therefore, HEME performance is independent of active process support and as a result this device is totally predictable and inherently more reliable than other high-efficiency devices, such as the HSS or electrostatic precipitators, whose performance would drop to zero in the event that active process support was lost.

The only important process variable that has been found to influence HEME DFs 'is superficial face velocity. When operated wet and at the upper end of its operating velocity range, solution transport of effluent through the filter bed and subsequent re-entrainment has been found to severely limit HEME performance (Goles 1986). Because HEME aerosol collection is dominated by diffusional effects in all U.S. vitrification plant designs, HEME performance has an unlimited turndown ratio; consequently, HEMEs have been sized very conservatively in all LFCM off-gas technologies to maintain face velocities of $\leq 5 \mathrm{ft} / \mathrm{min}$.

\section{HEPA Aerosol Scrubbing Efficiency}

A dual-filter HEPA filter assembly forms the last off-gas component in the process cell. Each filter will be mounted in this assembiy and individualiy tested, out-of-cel1, to achieve a removal efficiency of $99.97 \%$ for $0.3-\mu \mathrm{m}$ aerosols. The tested verified assembly will then be remotely installed in the LFCM's off-gas system. Since there will be no provision for in-place testing of this assemb7y, ANSI N13.1 (1969) only allows $99.9 \%$ efficiency to be assumed for the first filter and $99 \%$ for a second series filter. Under these rules, a combined aerosol DF of $1 \times 10^{5}$ can be claimed for this assembly, although significantly higher DFs are routinely achieved.

\section{Sand Filter Scrubbing Efficiency}

This device, like the HEPA assembiy, is designed to efficiently remove submicron aerosols from the exhaust gases passing through it. Its removal efficiency is designed and constructed to be $99.95 \%$ for $0.3-\mu \mathrm{m}$ aerosols. 
Because this filter is a completely passive off-gas component that requires no maintenance and cannot materialiy deteriorate, no real basis exists for derating its performance. Consequently, the șand filter has been assigned an aerosol DF value of 2000 for this study.

\section{PROCESS VESSEL VENT SYSTEM}

Discussions of LFCM process off-gas.systems have up to this point been mainly concerned with the melter off-gas component. Each of the three POG systems being considered in this report also has a process vessel ventilation (PV) system which exhausts effluents from process tanks that support HLLW and feed conditioning, secondary waste treatment, and.equipment decontamination activities. The number and types of vessers making up the DWPF, WVDP, and HWVP process vessel vent systems is a reflection of site-specific feed processing needs and will not be discussed here. What is of primary concern to this POG evaluation is the equipment used to decontaminate the PVV effluent source.

Apart from condensers and associated demisters servicing individual or groups of process vessels, the treatment systems used to abate PVV header emissions for the DWPF, WVDP, and HWVP are illustrated in Figures 10,11, and 12, respectively. The DUPF deep-bed washable filter represents the simplest of these vessel treatment systems; however, it should be noted that the exhaust from DHPF evaporator tanks is serviced by two condenser-demister treatment stages before the condenser overhead exhaust is discharged to the .PVW header and subsequent filtration. The WVDP, which has a relatively. simple in-cell vessel vent system, utilizes its MOG system's HEME and HEPAs to treat quenched PVV emissions. The HWVP PVV consists of an SBS and dua? HEPA filter assembiy. These components are also used as an emergency back-up for the MOG system should it fail. Each of the PVV treatment systems are clearly subsets of their corresponding MOG processing. system; consequentiy, the strengths and liabilities of these technologies can be easily derived from previousiy described performance information.

Being subsets, the emission abatement capabilities of the various PVV systems are inherentiy inferior to their MOG counterparts. The design simplicity of the post-condenser PVV treatment systems just described 
reflects the fact that physical entrainment of waste-containing liquids is the only significant contributor to PVV effluent emissions, and that . entrained aqueous effluent is much more easily abated than high-temperature melter emissions.

The main sources of PVV entrainment are evaporators, tank sparges, and vessel agitators. Of these emission sources, evaporation activities are, on the average, the greatest contributor to the overa 11 PVV source term. In al1 three vessel vent systems, condensers and associated demisters are used to abate entrainment losses. The DF expected from an evaporator-condenser combination is $>10^{4}$ (Christian and Pense 1977), and a DF of $10^{4}$ has been conservatively adopted as the design basis of DWPF vessel vent evaporation operations (Basic Data Report, DWPF. S7udge P1ant, DPSP 80-1033, Savannah River Laboratory). This DF, however, represents the partitioning of activity between the boiled-down liquid and the collected condensate. Airborne decontamination is several orders of magnitude greater than this; consequentiy, the total emission rates of airborne effluents, such as ${ }^{137} \mathrm{Cs}$, from the vessel vent header are found to be $\times 10^{4}$ times lower than corresponding effiuent release rates into the MOG treatment system (DPST 80-1033).

Because of these low concentrations, it is of little consequence which . of the three vessel vent systems exhibits the highest aerosol effluent abatement performance; overall POG system emission rates will be dominated and established by the MOG source term. As a result, MOG source terms can and will be used in evaluating the impacts of the three alternative POG systems upon HWVP environmental release rates of radioactive aerosols.

Radioactive gas emissions are not considered to be significant contributors to vessel vent airborne effluent, since (as previously discussed) PVV operations do not involve high temperatures nor strongly oxidizing collections. Potential volatiles such as ${ }^{106} \mathrm{Ru}$ and ${ }^{99} \mathrm{Tc}$ are not considered to be a probiem for the PVV operations so long as vessel solutions do not become too oxidizing; e.g.,.6 $\mathrm{M} \mathrm{H}^{+} \mathrm{NO}_{3}{ }^{-}$(Ondrejcin 1980). Since this cannot occur under any anticipated vessel processing conditions, volatile PVV emissions of the latter two isotopes are considered to be negligible. However, volatile vessel vent emissions of ${ }^{3} \mathrm{H},{ }^{14} \mathrm{C}$, and ${ }^{129} \mathrm{I}$ will occur to some extent, but since these gaseous effluents will be totally released into 
the melter off-gas system during high-temperature LFCM processing, the MOG can and will be considered the only major source for stack releases of these volatile radionuclides.

\section{BASES FOR PROCESS OFF-GAS SYSTEM EYALUATIONS.}

The evaluation of the effectiveness of DWPF, WWNS, and HWVP process. offgas systems for controlling HWVP environmental emissions is critically tied to the parameters and assumptions used in the evaluation. Consequentiy, the value of the POG system assessment is totaily dependent on the validity and appropriateness of the data used. Unfortunately, the current state of knowledge concerning feed composition, melter behavior, and off-gas system performance is subject to change. For this reason, large safety margins are built into this evaluation to accommodate the adjustments that inevitably wi17 occur. To properiy assess the impact of parameter changes on conclusions drawn in this document, it is necessary to cleariy establish the data base and the assumptions used in preparing this off-gas system assessment. These bases are discussed below.

\section{Performance Evaluation}

Atmospheric discharges of radioactive material from all operating facilities at the Hanford Site are regulated by but not 1 imited to 40 CFR Part 61, "National Emission Standards for Hazardous Air Pollutants; Standards for Radionuclides," U.S. Environmental Protection Agency, February 1985 (RHO 1987). This standard limits public exposure to a yearly whole body dose of 25 mrem and a 75 mrem dose to critical organs. In evaluating individual process sources that generate mixtures of radioactive effluents, derived concentration guides (DCGS) are commonly used to assess the impact of a specific source upon the overall site emission limitations. The relationship between DCGs and 40 CFR Part 61 dose 1 imitations can be expressed in terms of site boundary concentrations of radionuclides by the following expression:

$$
\sum_{i} \frac{C_{j}}{(D C G)_{i}} \leq 1
$$


where

$C_{j}=$ the concentration of radionuclide $" i n$

$(D C G)_{j}=$ the derived concentration guide for radionuclide " $i$ "

The above expression states that as long as the sum of radionuclide concentration ratios does not exceed 1 (the unity rule), public exposure rates will not, to first approximation, exceed regulatory limits. Although the unity rule cannot be used to establish compliance, it is useful in estimating the magnitude and relative contributions of individual emission sources upon the overall allowable site source term. If the unity rule is achieved by all site emission sources at the point of atmospheric injection (the stack), it is axiomatic that overall compliance at site boundaries will be assured. Consequently, it will be useful to compare the effluent emission characteristics of the three candidate process off-gas systems using stack radionuclide concentrations and corresponding DCGs according to Equation (1). By using this formalism, the relative merits of the candidate emission abatement systems can be assessed in terms of regulatory public exposure 1 imits.

It should be noted that comparative methodology adopted above only applies to contributions of the POG source to stack releases and does not represent an evaluation of the overall plant source term. Unfortunately, at this stage of design, the hot cell source, which is part of the heating, ventilation, and cooling (HVAC) system, is not well defined, even though it could be a be significant contributor to total plant releases. However once HVAC contributions have been established and applied to Equation (1), POG and HVAC results can be added together to evaluate the overall plant releases in termis of regulatory exposure limits.

\section{Feed Composition}

The composition and physical characteristics of the melter feed stream used in this study were extracted from several sources. The reference radionuclide content of the HWVP waste was obtained from SD-HWV-DP-001 (Hanford Waste Vitrification P1ant Reference Feed Radionuclide Content), and the gross chemical composition and physical characteristics of the melter feed were obtained from HWV-OCD-001 (Hanford Waste Vitrification P1 ant Feed Specification: Pretreated Neutralized Current Acid Waste Feed). 
Melter and off-Gas Performance

Melter performance is a processing variable that depends upon testspecific operating conditions, feed composition, and processing stability. Consequently a range of values exists for total melter loss rates as well as for individual elemental 1osses. To complicate the matter of establishing reference performance values, little correlation is found to exist between the variabilities of elemental DFs for similar classes of elements. As a result there is no common basis for comparing the results. of a statistically significant group of similar melter tests. The reason for this is that most elemental feed components are Tost by a combination of loss mechanisms whose relative importance is dependent upon test-specific process chemistry. Because of this, the best data base that can be used to represent the HWVP operations are results obtained from pilot scale simulations of the HWVP process. Therefore, empirical off-gas data have been utilized in the preparation of this POG system evaluation report. Specifically, the off-gas performance data collected during the recent HWVP-12/PSCM-22 melter test. (Nakaoka 1985). have been used extensively for defining the melter source term. However, comparisons with other data bases are discussed when appropriate.

The justification for selecting this data base for this evaluation. report is that the PSCM-22 test was stable, was fairly representative of the current HWVP design, and was well characterized. The more recent HWVP- . 13/PSCH-23 melter emission data (Goles 1989) were not used in this study because of the unusual processing stability and exceptionally high melter DFs that distinguished that test. Because of the Tower (and more conservative) melter DFs achieved during PSCM-22, equipment off-gas effluent sample sizes were significantiy greater than those collected during PSCM-23, thus allowing more accurate overall characterization of the integrated off-gas processing system. Literature values or data obtained from similar LFCM tests at PNL are used when PSCM-22 data are not available.

Although functionaliy similar to the HWVP melter off-gas system, the composition and operating conditions of the PSCM-22 off-gas processing system were not completely representative. Most notabiy, the PSCM-22 off-gas system employed an EVS quench scrubber; however, previous arguments have shown the 
EVS and SBS to be functionaliy equivalent. In addițion, the HEME was operated at or above the upper end of its design range. Because of these and other limitations, the criteria for assigning equipment performance values for the melter and all off-gas devices will now be discussed.

\section{Melter}

Melter performance was based on the sampling results obtained during the PSCM-22 melter test. For HWVP waste components not actually present in the PSCM-22 feed stream, off-gas data obtained from comparable LFCM tests were utilized whenever appropriate, or chemical simulants were used as substitutes. A summary of al7 non-PSCM-22 data used in this report is presented in Appendix A.

\section{Quench Scrubber}

The quench scrubber is the first component of the MOG system to treat the raw melter exhaust stream. It is designed to provide both off-gas quenching and effluent scrubbing functions. Assuming an operating temperature of $35^{\circ} \mathrm{C}$ and a water vapor saturated exhaust condition, a quench scrubber DF of 5 ( $80 \%$ steam recovery) has been assigned for tritium. An evaluation of the EVS used during the PSCM-22 melter test (Ruecker 1987) verified scrubber design compatibility with the conditions of the test. Since EVS and SBS technologies are functionally equivalent and PSCM-22 quench scrubber influent conditions are considered more typical than those observed during PSCM-23, the PSCM-22, EVS data base was utilized almost exclusively in establishing quench scrubber performance parameters. Exceptions are listed in Appendix A.

Idling performance values by necessity were obtained from PSCM-23 test results, as this was the only HWVP melter test where off-gas equipment performance was collected after feed processing was terminated. Because the idling condition does not involve many of the operating variables associated with feed processing, there is no reason to believe that PSCM-23 idling data are anything less than totally representative.

\section{Hydrosonic Scrubber}

This MOG component is specifically designed as a high-efficiency submicron aerosol removal device. Except for DWPF test data, very little 
operating experience is available for this device in LFCM applications. Because the mass median diameter of the spectrum of aerosols exiting the SBS have been shown to be submicron, the DHPF basic design value of 50 for HSS decontamination of cesium will be adopted for both semi- as well as nonvolatile aerosol effluent.

\section{Hiah-Efficiency Mist Eliminator}

This MOG system component is designed to remove condensed-phase aerosols from quenched LFCM exhaust streams. For the HWVP, this device serves as a demister for removing airborne water aerosols (fog) generated by the SBS and also acts as a deep-bed washable (regenerable) filter for reducing the concentrations of submicron particulate effluent. Because water vapor losses at $35^{\circ} \mathrm{C}$ have been shown to be responsible for most of the water loading in quenched melter off-gas streams, the demisting efficiency of the HEME, although quite high, will have little impact upon the overall tritium effluent source since it is mostly in the gas phase. Consequentiy, a tritium DF of 1 has been assigned to this device for the purposes of evaluating stack discharge concentrations of this isotope.

The airborne particulate effluent DF capabilities of this device, however, are a little more difficult to assign. As mentioned in the previous section, the HEME was operated at or above its upper velocity design specification during PSCM-22 (Ruecker 1987). Resultant performance measurements conducted during this test. were found to be lower than design expectations, as one might expect. Subsequent testing with an appropriately sized HEME during PSCM-23 resulted in significantly higher DFs; however, the combination of low process effluent emission rates and high efficiency made an accurate assessment of performance impossible during this test, although an overall lower limit mass DF of 400 could be established. This value is significantly greater than the basic DWPF design value of 50 , as it should be, since the mass median diameter of the challenge aerosol was not reduced by HSS pretreatment as it is in the DHPF design. Because the PSCM-23 HEME performance was found to be comparable, if not better than DWPF test data, a more realistic, although conservative, HEME DF of 100 has been adopted for all chemical classes of aerosol effluents in both the HWVP and WVDP off-gas designs. The DWPF reference design value of 40 has been retained for the 
DHPF HEME due to the influence of this technology's HSS upon both the size and concentration of HEME inlet aerosols.

HEPA Filter Assembly

This off-gas component is composed of a series arrangement of two HEPA filters. This MOG device is designed specifically to efficiently remove submicron aerosols from the process exhaust stream. Each filter stage in this assembly is tested in place and is therefore capable of providing a DF of $\sim 3000$ for highly penetrating $(0.3 \mu \mathrm{m})$ aerosols. Because the filter assembly is installed and maintained remotely and deterioration of gasketing material is inevitable, average filter performance will certainly be somewhat lower than the tested value. Additionally, aging and exposure to moisture and corrodants may decrease the ability of this filter assembly to maintain high DFs under unstable processing conditions. Because factors affecting .HEPA filter performance are difficult to predict in a remote environment, ANSI N13.1 (1969) only allows 99.9\% efficiency to be assumed for the first filter and $99 \%$ for a second series filter. Under these rules, a combined aerosol DF of $1 \times 10^{5}$ can be claimed for this assembly.

\section{Sand Filter}

This device, Tike the HEPA assembiy, is designed to efficientiy remove submicron aerosols from the exhaust gases passing through it. Its removal efficiency is fabricated to be $99.95 \%$ for $0.3 \mu \mathrm{m}$ aerosols. Because this filter is a completely passive off-gas component that requires no maintenance and cannot materially deteriorate, no real basis exists for derating its performance. Consequentiy, the sand filter has been assigned an aerosol DF value of 2000 for this study.

\section{Process Vessel Ventilation System}

As described in the previous section, the vessel ventilation effluent source is not a significant contributor to overall POG releases. This is primarily due to the fact that unlike the MOG, the PVV does not have to service high-temperature emission sources. Physical entrainment of wastecontaining liquids, resulting from evaporation, agitation, and/or sparging processes, is the only significant contributor to PVV aerosol emissions, 
and these effluent emissions are much more easily dealt with than are meltergenerated condensation aerosols (i.e. ${ }^{137} \mathrm{Cs}$ ). Consequent7y the MOG system will be considered the only significant contributor to plant releases of radionuclide aerosol.

With the possibie exception of tritium, PVV radioactive gas emissions $\left({ }^{14} \mathrm{C}_{2}{ }^{99} \mathrm{Tc},{ }^{106} \mathrm{Ru}\right.$, and $\left.{ }^{129} \mathrm{I}\right)$ are not considered to be important sources to the stack relative to $M O G$ contribution. This stems from the fact that the chemistry of feed and waste processing steps supported by the PVV are not designed nor are they capable of forming volatile compounds of these elements at any appreciable rate, while $100 \%$ of the $3 \mathrm{H},{ }^{14} \mathrm{C}$, and ${ }^{129} \mathrm{I}$ contained in slurry feed will be volatilized by the melter.

Vapor releases of tritium during concentration or evaporation processing steps are expected to be the largest PVV source of gas phase radionuclides. Since PVV system condenser temperatures will be at or below those used in the corresponding MOG system and noncondensible flows will be nominaliy equivalent; PWV 3 H losses will, at most, be equal to corresponding MOG' release rates. Although water saturation of the PVV exhaust is highly unlikely, this worst-case situation would act to double POG release rates, as process tritium losses are simply governed by temperature-dependent off-gas vapor loadings, as explained earlier.

To simplify performance analysis of the three LFCM off-gas technologies, PVV releases of tritium wi77 be included in the MOG source term since this is the only radionuclide of any potential consequence released by the PVV. Since little referable data exist regarding PVV effluent emission characteristics in general and tritium releases in particular, a water-vaporsaturated PVV exhaust stream will be assumed in this evaiuation--a worstcase situation. $\dot{A}$ temperature of $35^{\circ} \mathrm{C}$ will be assumed for all POG exhaust streams irrespective of the off-gas technology since any design variability is due to site-specific requirements, (e.g., $\mathrm{Hg})$, which are not applicable to the HWVP. Consequent7y, the MOG HTO DF will be derated to 2.5 to reflect worst-case POG loss rates of this tritium-containing compound. 


\section{ASSESSMENT OF POG SYSTEM PERFORMANCE}

Having established the bases for evaluating process off-gas emission rates, HWVP stack emissions will be projected using DHPF, HVDP, and HWVP offgas designs. From the previous descriptions of these technologies and the nature of the POG source term, it is obvious that the overall performance of the HWVP and WVDP off-gas systems is entirely equivalent. By similar reasoning, the DUPF off-gas technology will out-perform the other two systems for aerosol abatement simply by virtue of the additional. high-efficiency scrubbing stage provided by the HSS. A7though the HSS contributes a factor of 50 to the decontamination of the melter exhaust stream, its presence influences inlet conditions of the subsequent HEME, which reduces its efficiency (DF-100) by $40 \%$. Consequently, the DWPF technology can reduce POG stack-related emissions of radioactive aerosols by a factor of 20 over what can be achieved by the other two POG designs. The environmental. importance of this difference can only be appreciated and put into perspective by comparing HWVP stack emissions with environmental regulations.

\section{Normal Radioactive Emissions}

Using the data described in the previous section, plant emissions generated by the vitrification process have been estimated based on a $30-\mathrm{ga} / \mathrm{h}$ processing rate, a noncondensible off-gas flow.rate of $450 \mathrm{scfm}$ (HWVP Material Balance Flowsheet), and a stack dilution factor of 250 . Equation (1) was used to evaluate each off-gas technology at the point of atmospheric injection (the stack), where $c_{i}$ represents the projected stack concentration of a particular radioactive isotopic effluent. The results of the evaluation summarized in Table 14, indicate that the HWVP MOG system is fully capable of satisfying fenceline public exposure limits at the point of stack release. Based on preceding discussions, this result suggests that the HWVP cannot affect general site compliance with 40 CFR 61 providing that the cell source term does not have a dominating influence on overall plant releases.

The HWVP POG design is actually quite conservative with regard to aerosol removal capabilities. If the gaseous effluents of ${ }^{3} \mathrm{H},{ }^{14} \mathrm{C}$ and ${ }^{129} \mathrm{I}$ are excluded from the emission evaluation, overall MOG aerosol performance is 
TABLE 14. Projected HWVP Radioactive Effluent Releases (normal conditionș) ELEMENT CURIES/ MEITER QUENCH HERE HEPA SNDFLTR DILUTION LIMIT FRACT FRAET LIM

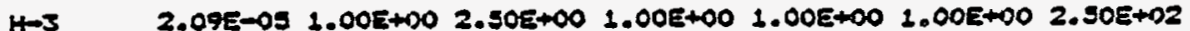
C-14 2.04E-06 $1.00 E+001.00 E+\infty 01.00 E+\infty 01.00 E+\infty 01.00 E+\infty 02.50 E+02$ FL-53 $5.07 E-032.60 E+02 \quad 9.20 E+01$ 1.00E+02 1.00E 005 2.00E+03 2.50E+02 NI-S9 3.08E-05 2.10E+03 $3.70 E+003.00 E+02$ 1.00E+0S 2.00E+03 2.50E+02 CE-t0 4.24E-04 2.60E+02 9.20E+01 $1.00 E+02$ 1.00E+0S 2.00E+03 2.30E+02 NI-63 $3.42 E-032.10 E+033.70 E+001.00 E+02$ 1.00E+0S $2.00 E+032.50 E+02$ 5r-79 $\quad 0.905-07$ 3.00E+01 $1.40 E+001.00 E+02$ 1.00E+0s 2.00E+03 2.505+02 SR-09 1.91E-16 2.30\%+02 $2.605+02$ 1.00E+02 1.00E+05 2.00E+03 2.50E+02 Y

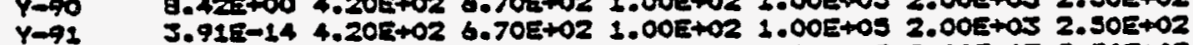
NB-93. 1.74E 1.04 4.20E+02 6.70E+02 1.00E+02 1.00E+0S 2.00E+03 2.30E+02 $2 R-93 \quad 2.965-044.20 E+026.70 E+021.00 E+021.00 E+032.00 E+03$ 2.30E+02 ZR-95 $\quad 8.24 E-13$ 4.20E+02 $6.70 E+02$ 1.00E+02 1.00E+05 2.00E+0j 2.30E+02 NE-95 $1.90 E-124.20 E+02$ 6.70E $+021.00 E+021.00 E+052.00 E+032.50 E+02$ TC-99 $2.125-053.00 E+02$ 2.20E+02 $1.008+02$ 1.00E+05 2.00E+03 2.50E+02

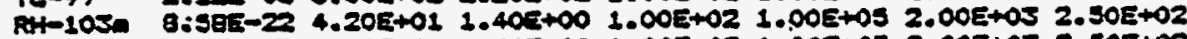
RUT-103 9.31E-22 4.20E+01 $1.40 E+001.00 E+021.00 E+052.00 E+032.50 E+02$ RAI-106 1.18E-02 4.20E+01 1.40E+00 1.00E+02 1.00E+05 2.00E+03 2.50E+02 Rt+106 1.18E-02 4.20E+01 1.40E+00 1.00E+02 1.00E+05 2.00E+03 2.50E+02

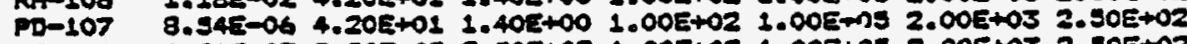
AG-110m $6.26 E-07$ 2.30E+02 $2.30 E+02$ 1.00E+02 $1.00 E+032.00 E+032.30 E+02$

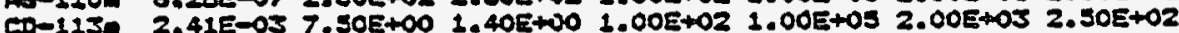
IN-113. 2. SN-113 2.84E-1: 4.20E+02 6.70E+02 1.00E+02 1.00E+05 2.00E+03 2.50E+02

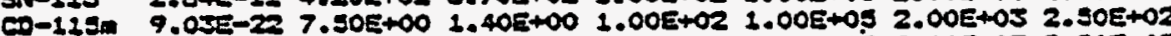
SN-119m 1.92E-06 4.20E+02 6.70E+02 1.00E+02 1.00E+0\$ 2.00E+03 2.30E+02

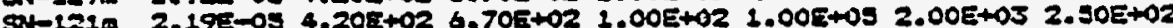

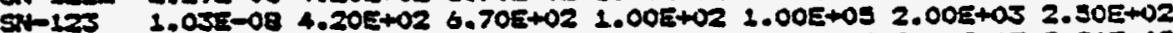
ST-126 1.0JE-04 4.20E+02 $6.708+02$ 1.00E+02 1.00E+0S 2.00E+03 2. SOE+02 SB-124 3.26E-18 4.30E+02 3.00E+01 1:00E+02 1.00E+05 2.00E+03 2.30E+02

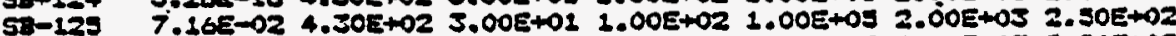
59-126 1.44E-05 4.30E+02 3.00E+01 1:.00E+02 1.00E+05 2.00E+03 2.50E+02 SB-126m 1.0JE-04 4.30E+02 $3.00 E+01$ 1.00E+02 1.00E +05 2.005+03 2..S0E+02 TE-1ZER 1.75E-02 1.10E+01 1.40E+00 1.00E+02 1.00E+05 2.00E+03 2.50E+02 $T E-1=7$ TE-127m TE-129 TE-129m $1-129$ $\operatorname{cs}-134$ $\operatorname{cs}-1 \div 2$ BA-137m $05-137$ CE-141 CE-144 $P R-144$ PR-144 PH-147 PM-14Ea SM-151 Eu-152 GD-15

마-154

2u-155

$78-160$

$u-254$

U-235

$4-236$

$4-258$

Nip-257

PU-238

pur-239

PU-240

Ax-241

Pu-241

Ant-242

Cor-242

pul-242

art-245 1. BEE-09 1.10E+01 1.40E+00 1.00E+02: 1.00E+0S 2.00E+03 2.50E+122 1.

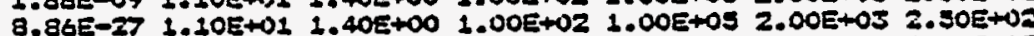

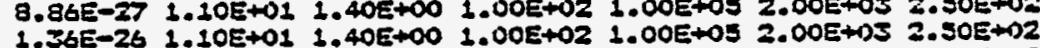

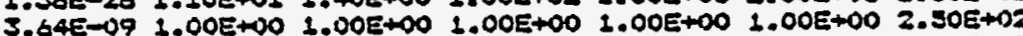
2. GSE-O2 1.40E+01 1. $40 E+00$ 1.00E+02 1.00E+05 2.00E+03 2.30E+12 3.71E $\rightarrow 5$ 1. $40 E+01$ 1. $40 E+00$ 1.00E+02 1.00E+D5 2.00E+0.3 2.30E+02

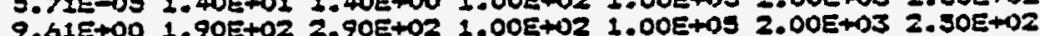
1.0DE+01 1.40E+01 i. $40 E+00$ 1.0OE+102 1.00E+03 2.00E+03 2.5OE+02 9. $27 E-264.50 E+02$ 4.40E+02 1.00E+02 1.00E+1)5 2.00E+1)3 2.50E+02

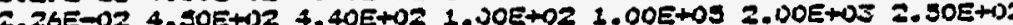
$2.26 E-022.09 E+021.70 E+02$ 1.00E+02 1:00E+05 2.00E+1)3 2.50E+102 $2.71 E-042.09 E+132$ 1.90E+02 1.00E+02 1.00E+05 2.00EW-13 2.5OE+02 $1.47 E+002.09 E \div 02$ 1.90E+02 1.00E+02 1.00E+105 2.00E+03 $2.50 E+1.2$ 1.76E-22 $2.09 E+02$ 1.9(E+1)2 1.00E+102 1.00E+05 2.00EW0. 2. E.0E+02 $1.97 E-01$ 2.09E-02 1.70E+02 1.00E+02 1.00E+0S 2.00E+1J 2.50EWO2

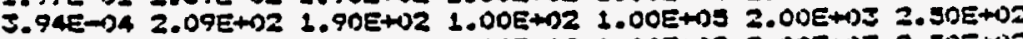
$3.91 E-292.09 E+02$ 1.90E+102 1.00E+02 1.00E+05 2.00E+1)3 2.50E-1.2 $4.095-02$ 2.09E+02 1.90E+02 1.00E+02 1.00E+05 2.00E+n3 2.50E+102 3. $88 E-02$ 2.09E+02 1.90E+02 1.005+02 1.00E+05 2.00E+03 2.50E+02

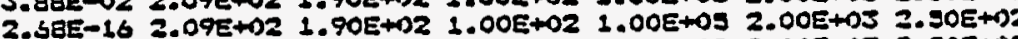
1. 5.04E-08 4.50E+02 3. 20E+02 1.00E+02 1.00E+0S 2.00E+03 2.SOE+02 $1.19 E-07$ 4.50E $\rightarrow 02$ 3.20E +02 1.00E+02 1.00E+05 2.00E+123 2.5OE+1)2 $9.91 E-07$ 4.50E+02 3.20E+02 1.00E+02 1.00E+09 2.00E+DS 2.SOE+102

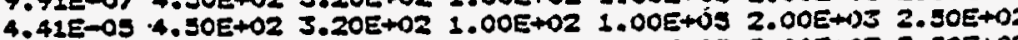
1.25E-04 4.50E+02 3.20E+02 1.00E+02 1.00E+05 2.00E+03 2. S0E +02 3.J1E 04 4. SOE+02 J.20E +02 1.00E+02 1.00E+05 2.00E+03 2.50E+102 1.

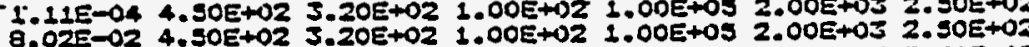
3. 5 EE-03 4.50E+02 3.20E+02 1.00E+D2 1.00E+05 2.00E+03 2.50E+02 $4.24 E-05$ 4.5OE+02 J.20E+02 1.00E+02 1.00E+05 2.00E+03 2. JOE +02

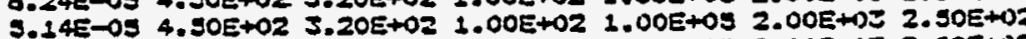

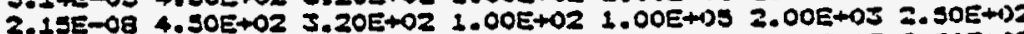

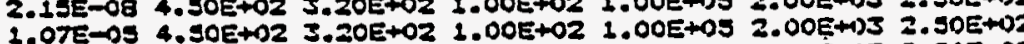
$1.425-03$ 4.50E+02 $3.30 E+02$ 1.00E+D2 1.00E+1)S 2.00E+U3 2.50E+02

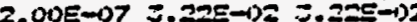
. 00E-09 उ.14E-01 उ.46E-1)1

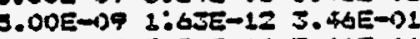
4.00E-09 3.81E-14 J.44E-D1 9.00E-11 8.52E-12 $3.46 E-01$ $3.00 E-09$ 9.46E-12 $3.46 E-01$ 1.00E-09 4.89E-13 3.44E-01 3.0OE-10 3.24E-25 3.46E-01 $9.00 E-12$ b.025-07 3.46E-01 3.00E-0E 3.84E-11 \$.46E-01 $3.00 E-101.78 E-23$ 3.46E-1) 4.00E-10 5.95E-14 3.46E-O1 $1.00 E-16$ 4.0EE-17 3.46E-D1 6. DOE- 10 1.8EE-22 3.46E-01 3.00E $\rightarrow 29$ 9.665-23 3.46E-DI $2.00 E-09$ b.18E-13 =.46E-1 $3.00 E-06$ 1. $97 E-32 \quad 3.46 E \rightarrow 1$ 2.00E-19 $3.11 E-28$ 3.46E-1)1 - .00E-11 2. 27E-07 उ. $36 E D \rightarrow 1$ $1.00 E-127.7250136$ 3.46E-1) $9.005-10$ 6.21E-12 3.46E-01 2.00E-10 1.93E-15 3.46E-1) 3.00E-12 $1.10 E-06$ 3.46E-1 $3.00 E-17$ 1.52E-22 ₹.46E-01 $1.005-09$ 3. a8E-21 $5.46 E-1$ 2.00E-10 1.6EE-26 J.46E-1)1 $2.00 E-09$ 1. $21 E-16$ 3.46E- 1 $1.00 E-092.99 E-15=.46 E-1) 1$ $4.00 E-103.575-183.46 E-11$ $1.00 E-10$ 1. $11 E-13=.46 E-1) 1$ $6.00 E-10$ 1.52E-2S 3.46E- 1 $1.00 E-09$ 2.1JE-10 $3.46 E-1) 1$ $1.00 E-09 \cdot 4.2 F E-143.46 E-1$ $4.00 E-077.6$ 7E-16 3.46E-.)1 2.00E-139 2.19E-08 $3.46 E-1) 1$ $5.00 E-08$ 9.24E-17 3.46E-1)1 b. $00 E-10$ 7.3 $3 E-15$ 3.46E $\rightarrow 1$ $0.00 E-07$ 1.11E-34 =.46E-11 $6.00 E-10$ 5.66E- 32 J.46E-DI $7.00 E-11$ 4.0OE-02 3. $96 E-11$ $2.00 E-10$ 2. $38 E-17=.36 E-1) 1$ $=.00 E-19=.7 J E-11$ 3.96E-1) 1 $3.00 E-19$ 2.24E-10 J.36E-11 $4.00 E-10$ S.ODE-0S $3.86 E-11$ 1.0DE 19 1.S1E-J $=.36 E-11$ 3. ODE-11 $1.40 E-10$ 3.26E-D1 $3.00 E-1 ; 7$ 7.JOE-14 3. $36 E-1 ? 1$ $1.00 E-12=0.6$ AE-10 3.36E-11 3. .OOE-10 4.75E-1)9 J.36E-1): $7.00 E-10$ 2. $44 E-21$ J.56E-.12 $4.00 E-10$ 4.77E-10 j.86E-11 $5.00 E-117.635-1=3.365-11$ $5.00 E-10$ 0.15E-18 $5.36 E-1) 1$ 5.00E-11 7.925-10 3.86E-01 $3.00 E-10$ 1. $35 E-10$ 3.86E-1)1 5. $00 E-10 \quad 5.19 E-25$ 3.86E-1)1 9.00E-14 3.8ZE-12 इ.86E-1)1 1. OOE-1S 1.JJE-13 3.86E-1)1 1.00E-13 3. $38 E-13$ 3.96E-1)1 1.0OE $-1=2.65 E-12$ J.86E-D1 2.0OE-14 $5.99 E-10$ 3.36E-1)1 3.0OE-14 $1.11 E-09$ 3.86E-1)1 2.00E-14 4.4ZE-09 $=.86 E-11$ 2.0OE -14 1.48E-09 3.86E-1) 2.0OE-14 1. OTE-OG 3.86E-O1 $1.00 E-129.48 E-10$ उ.86E- 01 2.0OE-10 8. उEE-14 3.86E-1)1 $7.00 E-131.96 E-11=.36 E-11$ 2.00E-14 2.87E-13 $3.86 E-1$ $2.000-14$ 1 4 TE-10 =

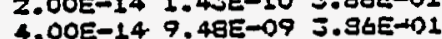


found to be orders of magnitude greater than that required by the emissionlimiting condition described by Equation (1). When it is considered that conservatively low performance values were assigned to the HEME and HEPA filters for this assessment, it is fair to say that the HWVP MOG system provides an adequate safety margin to handle process excursions that affect overal1 MOG system performance. From another point of view, the high projected aerosol abatement efficiency of the POG system provides the HWVP with great latitude in accommodating particulate effluents generated from the HVAC source whose magnitude remains to be established.

The impact of gaseous radionuclides on allowable plant releases is clearly underscored by the dominating influence of ${ }^{14} \mathrm{C}$ (and to a lesser extent ${ }^{3} \mathrm{H}$, and ${ }^{129} \mathrm{I}$ ) on the fractional integrated release 1 imit defined by Equation (1). The influence of the gaseous radionuclides will not be affected by any of the three POG technologies being considered in this study. Consequently, when the fractional integrated release 1 imit is considered for a17 radiologically important LFCM gaseous effluents, HWVP stack emissions resulting from all three process off-gas technologies are found to be indistinguishable and equivalent.

In summary, of the three off-gas technologies employed in U.S. vitrification facilities, the DUPF process off-gas system was found to be $20 \mathrm{X}$ more efficient for condensed-phase aerosol removal than the functionally equivalent WVDP and HWVP systems. However, when emissions of volatile radioactive isotopes are considered, all off-gas technologies are found to be equivalent when compared on the basis of annual public exposure 7 imits, due to the dominating influence of volatiles on the overall source term. All off-gas technologies were found to abate radioactive emissions sufficientiy to meet 40 CFR 61 limits at the point of stack discharge.

\section{Off-Normal Emissions}

Nonroutine processing conditions such as melter instabilities, increased off-gas flow rate, and failure of the MOG system and its individual components all could be expected to affect off-gas processing efficiency and resultant plant releases. The effects of each of these circumstances are discussed below. 


\section{Melter Instabilities}

Unstable melter processing is one of the more common upset situations that can and will occur during vitrification campaigns. Erratic or overfeeding conditions are the most common causes for these upsets, which usualiy result in significant decreases in meiter aerosol DFs (see Table 5). As discussed earlier, melter upsets of this type onily serve to increase the concentration of large-diameter $(>1 \mu \mathrm{m})$ entrained aerosols in the MOG system. Since quench scrubbers can effectively deal with this type of effluent, overall melter-quench scrubber DFs rarely change and quenched offgas effluent characteristics are usually not perturbed; consequent7y, unstable melter processing conditions will not, in general, increase stack aerosol emission rates.

Unstable processing conditions also result in erratic and sometimes convulsive melter gas generation rates, as discussed previousiy. Indeed, the frequency and magnitude of off-gas flow surges are often used to indicate the onset of processing difficulties. Figure 3 illustrates flow and concentration variations resulting from such an off-gas surge event. Kessler and Randal1 (1984) conducted a study of LFCM melter off-gas flow variations which resulted in a statistical model relating surge event magnitude with frequency of occurrence. The results of their studies showed that a $7 X$ flow surge would, on the average, occur once every 200 days while a $10 X$ events would occur at i3 year intervals. From a very conservative standpoint, these data suggest that unstable processing conditions could increase average POG plant gaseous emissions by as much as an order of magnitude once every processing year. Since gaseous radionuclides dominate the HWVP POG source term, the sum of fractional DCGs given by Equation (1) might be expected to exceed the (stack) unity condition over short periods ( 5 min) at very infrequent intervals $(-1 / y r)$.

A7though infrequent, short-term excursions in POG flow surges could cause the DCG unity condition to be exceeded by as much as a factor of 4 at the stack, atmospheric dispersion will reduce the stack radionuclide concentrations by at least five orders of magnitude at site boundaries where public dose regulations are imposed (Andrews and Rhoads 1989). Thus process flow surges of and by themselves cannot create unsafe public exposure 
conditions, but they can influence the overall site source term which is, after all, what is being regulated. The degree to which surge events affect the magnitude of the site source will not be estimated here since it requires a detailed knowledge of all site sources and area meteorology and is clearly beyond the scope of this report. However, the affects of flow surges are independent of the off-gas technology employed, as all systems being considered possess equivalent gaseous effluent abatement capabilities.

\section{Off-Gas System Flow Rate}

Inleakage increases in off-gas flow rates can also deteriorate melter - off-gas treatment performance. Quench scrubber performance, as discussed earlier, has been shown to be quite insensitive to flow rate changes. Similariy, HSS effluent removal mechanisms are not expected to be particularly sensitive to flow changes of this type, but HEME performance apparently is. At superficial face velocities of $>35 \mathrm{ft} / \mathrm{min}$ overal1, HEME mass DFs have been limited to values of $-10-1 / 10$ of its (HWVP) assigned value at a $-5 \mathrm{ft} / \mathrm{min}$ face velocity (Goles 1986). A7though an average, sustained noncondensible flow increase of $>2 X$ is not possible in any of the off-gas technologies considered here, flow rate increases could very well deteriorate HEME performance to some extent. But even under worst-case conditions of a $10 \mathrm{X}$ reduction in HEME aerosol DF, the POG source (see Table 14) would still be dominated by the releases of gaseous radionuclides $\left({ }^{14} \mathrm{C}\right)$ as they are over three orders of magnitude more influential in establishing projected $p 7$ ant contributions to public exposure than are radioactive aerosols. As in the case of off-gas flow surges, the above conclusion is independent of the offgas technology used.

\section{MOG System Failure}

Failure of the primary melter off-gas system would, in general, have a varying impact upon $\mathrm{plant}$ emissions depending upon the POG technology. employed. As previously described, the DWPF POG system design has a totally redundant MOG system; thus, no changes in plant stack emission rates would occur upon switching to the auxiliary train. Failure of the MOG system in the WVDP design would, on the other hand, dramatically increase plant radioactive aerosol emission rates, as there is no MOG back-up exhaust system. Without backup, WVDP melter emissions would have to be vented to the process 
cell which, for the HWVP, is unfiltered. Should this situation occur in a process cell like that of the HWVP, melter airborne effluent would only be abated by settling, surface deposition, and sand filter removal mechanisms. For submicron condensation aerosols $\left({ }^{137} \mathrm{Cs}\right)$ the sand filter would provide the greatest barrier (DF $=2000$ ) between process emissions and the stack. A transient condition such as this would invariably result in unacceptable stack releases. Clearly the WVDP. POG system is not totally compatible with HWVP (or DWPF) process cell design.

The HWVP POG system utilizes its PVV as an auxiliary melter off-gas system should the primary system fail. As described earlier, the HWVP vessel vent treatment system provides a 17 MOG treatment capabilities except for HEME filtration. All things being equal, the back-up system will provide a 100-fold decrease in aerosol decontamination and a corresponding increase in stack emission rates. However, because LFCM processing would cease once the back-up system was employed, melter emission rates for most effluents will decrease significantly as the effluent source term. is an idling melter. On the other hand, quench scrubber DFs will decrease since idling melters predominantly produce submicron aerosols. To project the impact of this type of off-normal condition upon plant emission rates, melter and quench scrubber performance data collected during PSCM-23 id7ing studies were used with previously described HEPA and sand filter data to calculate radioactive stack releases, assuming that only semivolatile emissions are important and that their emission rates are comparable to those occurring under normal processing conditions. The results of these calculations, which are surmarized in Table 15, show that MOG failure would lead to a projected 100-fold increase in emission rates of radioactive aerosols; however, the resultant increase in POG aerosol release rates would not raise the fractional DCG limiting sum, given by Equation (1), above the unity condition at the stack. Since the aerosol source term of the back-up MOG is projected to be only $1 \%$ of that of gaseous radionuclides released during processing, emergency use of the backup HWVP MOG should not significantly increase the environmental impact of plant operations and the unity condition at the stack should be maintained. 
IABLE 15. Projected HWVP Radioactive Effluent Releases (MOG back-up)

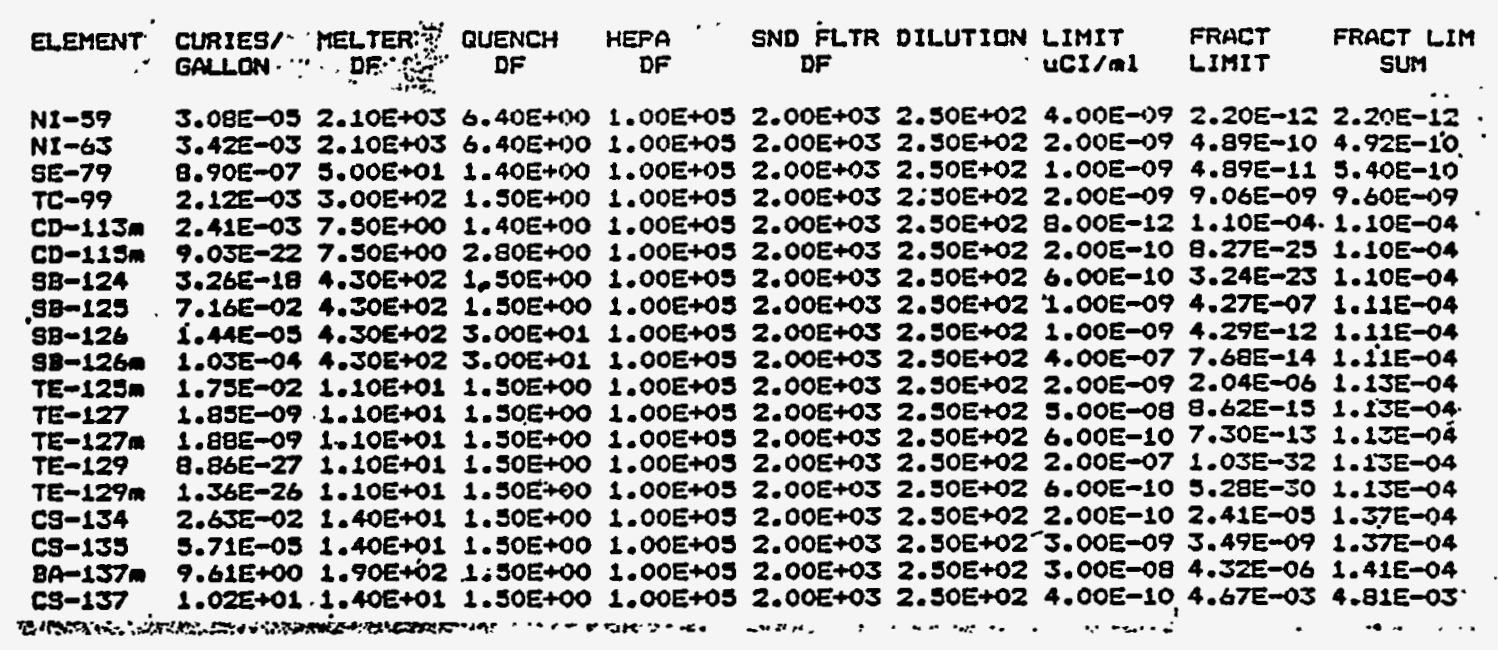

\section{Off-Gas Equipment Failure}

Although the HWVP and WVDP POG designs are potentially more sensitive to process-induced changes in overall system aerosol scrubbing performance than is the DWPF, the DWPF design is much more vulnerable to disruptions or interruptions in process support services. Both the HWVP and WVDP systems are . composed of more or less passive components. Interruption of services to any one or a combination of these devices would have no significant short term (hours) impact upon overall system performance.

Some DHPF off-gas components, on the other hand, require active support to function. Specifically, the performance of the EVS is critically linked to the services of a fluid recirculation pump. Pump failure would result in the loss of both quenching and scrubbing functions. The HSS scrubbing function would be similarly lost by either pump or steam service failure. A functional loss of the HSS scrubber would reduce DWPF MOG system efficiency to HWVP and HVDP POG design values which, from the stand point of public health and safety, have been shown to be entirely adequate; however, loss of the EVS would have to be treated as an MOG failure since the functional design criteria of all subsequent devices are based upon off-gas pretreatment by the quench scrubber. Consequentiy, processing would have to be terminated, and the melter would have be vented to the auxiliary off-gas system. Transient releases associated with such an event would not be expected to be 
excessive so long as the back-up system was promptly employed; however, recovery and cleanup of the primary (DWPF) MOG could produce significant cell contamination and cause a chronic increase in the plant's cell ventilation source term.

\section{Conciusion}

The off-gas performance characteristics of the DWPF, WVDP and HWVP offgas processing systems have been evaluated under normal and off-normal processing conditions for specific application to the HWVP project. - The projections are that under normal processing conditions all three systems will behave similarly and provide nominally equivalent public exposure protection due to the dominating influence of gaseous emissions of trace (curie basis) waste components $\left({ }^{3} \mathrm{H},{ }^{14} \mathrm{C}\right.$, and ${ }^{129} \mathrm{I}$ ).

The impacts of the various off-normal POG conditions upon the normal HWVP source term appearing in Table 14 have also been modeled. Of these offnormal conditions, off-gas flow surges and failure of the primary melter offgas system represent worst-case conditions relative to increasing overall plant stack emissions. Transient increases in melter gas generation rates, surging, were found to have the greatest effect on the HWVP source term. However, since all POG systems under consideration possess equivalent gaseous effluent abatement capabilities, all off-gas technologies were found to behave similarly. Because the HWVP source term is dominated by the release of gaseous radionuclides, melter off-gas surges $>3 X$ are capable of increasing stack discharges above the DCG unity condition defined by Equation 1, independent of the POG system employed. However atmospheric dispersion will reduce radiological stack concentrations by several orders of magnitude at site boundaries.

Untike off-gas surging events, the environmental impact of a failed primary MOG system was found to be off-gas technology dependent. Specificaily the HVDP POG system is incompatible with the unfiltered HWVP process cell design as its MOG system has no backup. The vessel vent backup to the HWVP MOG was found, on the other hand, to be entirely adequate for dealing with MOG failure conditions involving the HHVP POG technology. Under worst case conditions, a 1\% increase in normal stack emissions would result from this type of failure since gaseous radionuclide releases dominate the HWVP 
processing source. Idling aerosol. emission rates, however, would increase by a factor of 100 , although the environmental dose associated with idling is projected to be only $1 \%$ of that associated with normal processing conditions due to the absence of radiologicaliy important gaseous effluents. The DWPF POG technology is found to be unaffected by failure of the primary MOG system, as it possess a total7y redundant MOG backup system. With the DWPF POG system neither short (emergency venting) or long term (idling) use of the backup system would impact normal stack emissions.

A7though the DWPF system provides equal or greater aerosol effluent decontamination under most off-normal conditions considered, projections of this study suggest that the HWVP POG design wi17, except under idling, provide equivalent exposure protection to the public since aerosol contributions to the overall HWVP source is Sma17. In fact both POG systems are capable of meeting public exposure 7 imits at the point of atmospheric injection under al1 normal and upset conditions except for $>3 \mathrm{X}$ off-gas process surges. The WVDP POG, however, was found to be incompatible with the HWVP cell design under general MOG failure conditions. 



\section{SECONDARY WASTE GENERATION}

\section{INTRODUCTION}

Secondary wastes are defined as the extraneous materials generated by normal operation of the process that are not directly treated by the process. The handling and disposal of secondary wastes can result in additional costs, energy consumption and environmentaT impacts. The quantity of secondary wastes are one consideration (along with the ability of the systems to meet cleanup criteria, costs, environmental impacts) in choosing which off-gas treatment system should be employed for the process. For the purposes of this evaluation, various systems for vitrification process off-gas treatment are considered in the context of (HWVP) proposed guidelines. As such, the anticipated secondary wastes from the off-gas system (the melter off-gas system and vessel vent system) from a waste vitrification process are the following:

\section{Solid Wastes}

- contaminated clothing and supplies used in operations (e.g., process, maintenance and repair)

- spent high-efficiency particulate air (HEPA) and other filters (NOx removal is not considered in this study)

- failed equipment (and dunnage) that cannot or will not be repaired

- all piping, equipment and instrumentation that must be decontaminated and decommissioned after use.

\section{Liquid Wastes}

- spent aqueous solutions or steam used to decontaminate the celt, piping (jumpers) and equipment for maintenance, repair or disposal

- 10w-level. liquid process wastes (process condensate, scrub solutions, etc.).

\section{Gaseous Hastes}

- heat released to the cell exhaust via heat transfer from the process vessels and equipment.

The excess heat from operations released to the cell exhaust is not considered to significantly increase the heat load and the three processes 
considered for this study (HWVP, WVDP, and DHPF) utilize similar heating and cooling steps in their off-gas systems. The secondary heat generation load has been calculated and is already considered in planning for the cooling needed for the plant exhaust gases. Thus, significant differences of costs are not anticipated from this source and this element is not considered in the evaluation.

\section{EMISSION CONTROL TECHNOLOGIES(a)}

Relevant HWVP Guidelines

Various proposed guidelines for the handling of wastes from the HWVP affect the relative importance of the two classes of secondary waste. Currently, the oniy available option for disposal of solid wastes is burial. It is assumed that solid wastes will be managed to reduce the volume to some reasonably low level. Most of the solid wastes considered are metal equipment and, as such, their weights are an index of the amount of solid secondary waste generated.

Low-level process generated and decontamination liquid wastes will both receive treatment to remove transuranics and significant radionuclides. The low-level aqueous solutions are evaporated to reduce the volume and grouted. Although not part of this analysis, it should be noted that evaporation requires energy. The condensate from the evaporation of the low-level solutions is further treated by an ion exchange column until the solutions meet relevant standards for discharge to a ground column.

\section{Off-Gas Treatment Systems}

The various technologies for controlling the airborne emissions from waste vitrification employed by the three facilities are described in previous sections. There are essentially two systems: System $A$, which is proposed by the HWVP and WVDP; and System B, the system proposed by the DHPF. The individual equipinent used by these technologies are listed below: Some of the individual components of the systems are essentially passive; they do not require mechanical movement to function (e.g., SBS). Others are

(a) (Anon 1988, Anderson 1988, Barnes 1988, Bul1 1988). 


\section{SYSTEM A}

Melter Off-gas System

Film cooler (FC)

Submerged bed scrubber. (SBS)

High-efficiency mist eliminator (HEME)

Heater

Roughing/HEPA filter

Blower/exhauster
Process VVS

FC

Condenser (a)

SBS (b)

Heater (b)

Roughing/HEPA filter(b)

(a) Used by HVDP only.

(b) Used by HWVP onty.

SYSTEM B

Melter Off-gas System

FC

Quencher

Off-gas condensate tank (OGCT)

Steam-atomized scrubber (SAS), two stages

Condenser

HEME

Heater

Roughing/HEPA filter

Blowers

\section{Process VVS}

Condenser

Heater

Filter

active (e.g., SAS). An important component of both systems are pumps that move the liquid from one location to another and are used for sampling. Pumps are mechanical items and wear with time. Pumps operated continuously wear faster than pumps that are operated intermittent7y (IEEE 1984). Thus, systems and components that are passive and do not utilize a large number of pumps will generate less solid and Tiquid (decontamination solutions) wastes. The operational consideration of importance to the generation of secondary wastes for each type of equipment is discussed below: 


\section{Melter Off-Gas System A}

Film Cooler. The function of the FC is to transport the aerosol generated by the melter without significant loss of particulate materials by deposition and controlling the off-gas temperature so that entrained materials do not vitrify (thus clogging the cooler) and vaporized salts do not condense. This function is accomplished by the injection of air or steam along the walls of the cooler (see Figure 25). The cooler does not itself generate liquid wastes (the steam, particulate loading are removed in subsequent pieces of equipment). It is a passive item and, if properiy operated, should not be excessively worn during use. Failure could occur by clogging or corrosion if improper materials enter the system or the equipment is operated under improper conditions. An average failure rate of 9000 hours is assumed, and 2 batches of 40 liters ( 10.57 gallons) each are required to decontaminate the FC for repair or disposal.

Submerged Bed Scrubber. The function of the SBS is similar to a gas scrubbing column: to remove the bulk of the entrained solids and c00l the off-gases. The off-gases enter the. SBS below a screen supporting a packed bed (Figure 26). Liquids from the HEME, slurry mix evaporator condensate tank (SMECT) and the de-entrainment device on the outlet of the SBS are used to scrub gases, vapors and particulate materials from the off-gases. Contact. between the liquid and gases is via the gas bubble-liquid interface where liquids and particles can be dissolved/captured by the liquid. In the case of the gas column, the bubble size is dependent upon the gas volume flow rate or scrubbing can be enhanced by sieve plates. In the SBS, the off-gas breakup is determined by the space between the components of the packed bed. Intimate contact between the phases is assured by the liquid's presence in the packed bed. In the case of the submerged bed, the liquid can be cooled and the device can also function as a condenser for vapors such as water whose boiling temperature is considerably greater than the operating temperature of the device. The SBS condenses approximately $100 \mathrm{lb}$ of water/hour from the FC. The SBS also accumulates water from the HEME $(2.6 \mathrm{~Tb} /$ hour $)$. The liquid is accumulated in the bottom of the SBS by gravity flow and covers 


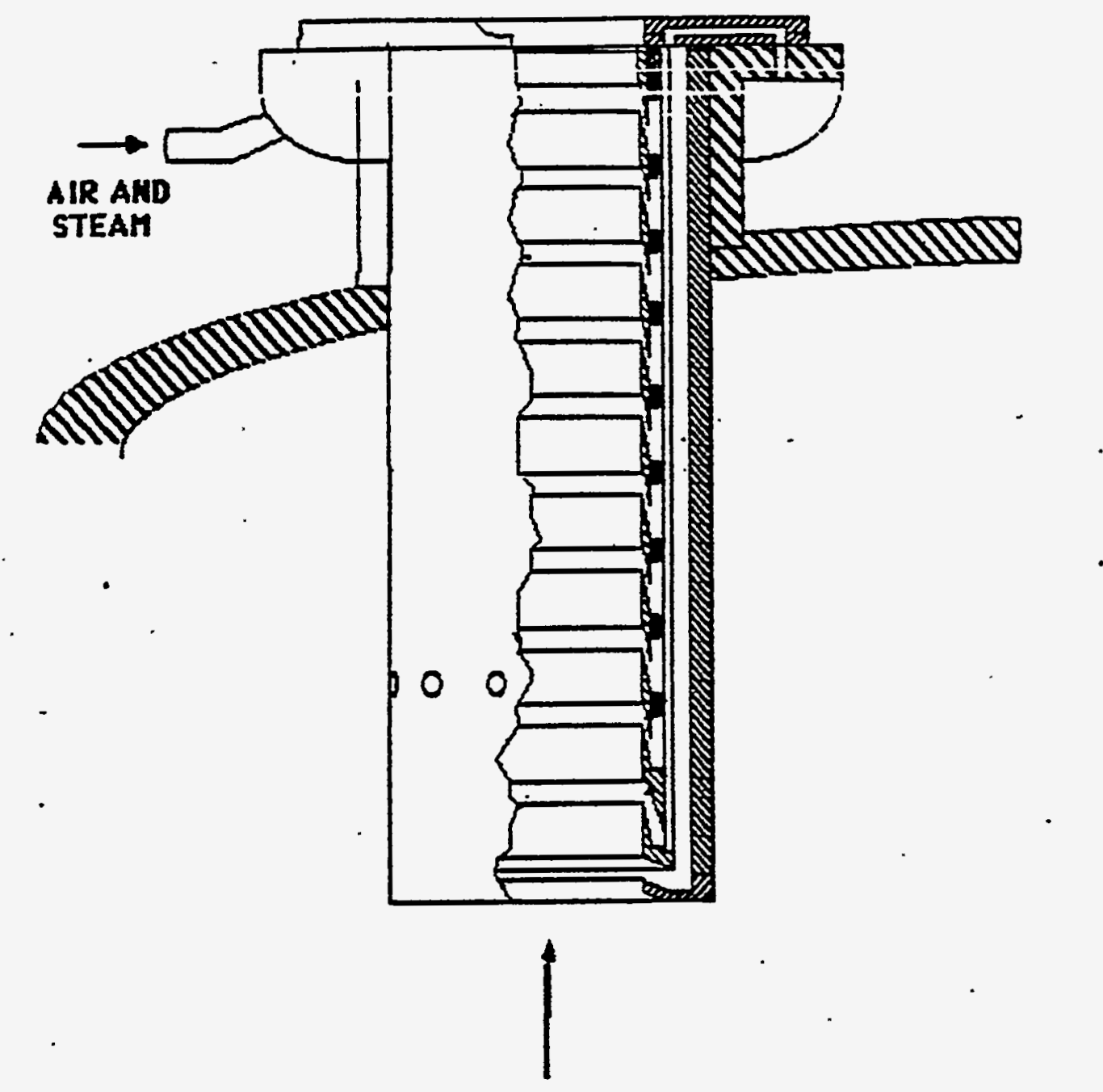

MELTER OFF-GAS

FIGURE 25. Off-Gas Film Cooler

the packed bed. Excess aqueous solution (approximately $103 \mathrm{lb} / \mathrm{hour}$ at steady state) is intermittently pumped from the SBS. An average failure rate for pumps of 4000 operational hours is assumed.

Operation of the SBS is passive: the buoyancy of the incoming gases and the differential pressure generated by the blower provide the motive force. As such, the SBS has few if any moving parts and should be relatively durable. The SBS is essentially a vessel with a cooling coil and pump attached. An average failure rate of 300,000 hours is assumed for the SBS. If the pump 


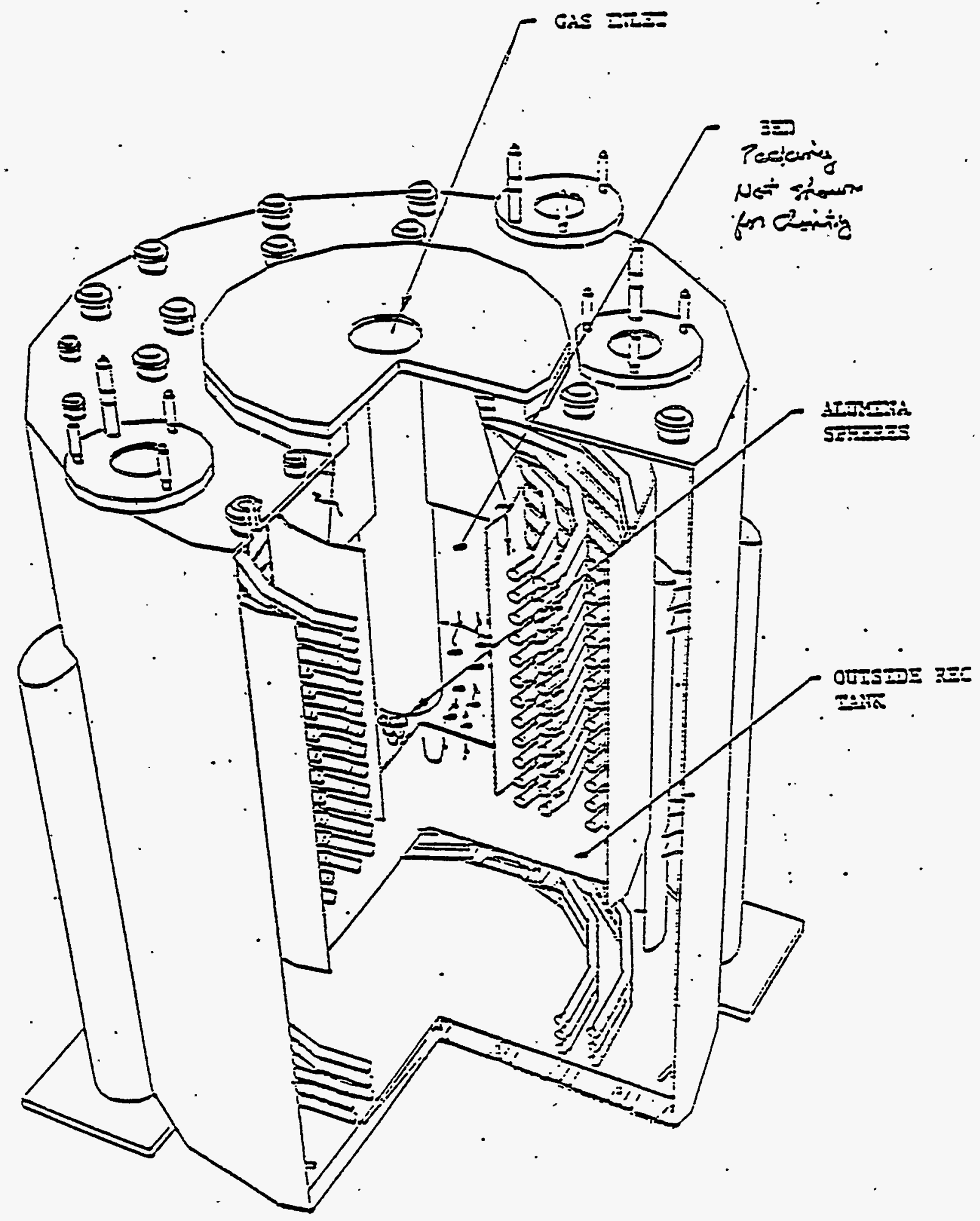

FIGURE 26. Submerged-Bed Scrubber 
operates 1 hour for each 75 hours of SBS operation (accumulation of approximately 966 gallons of excess aqueous solution), the pump should not limit the duration the SBS could remain in operation. Ten batches of 40 liters (10.57 gallons) each are assumed to be required to decontaminate the SBS for repair or disposal.

High-Efficiency Mist Eliminator. The HEME filters proposed for System A utilize a single, large, cylindrical, packed fiber bed (see Figure 27). For the HHVP system, off-gases enter in the central annulus of the bed and process water is allowed to flow down the inner face of the coarser, less densely packed fiber bed to minimize the accumulation of vapors and particulates on the bed. "Wicking" (the transmission of water through the

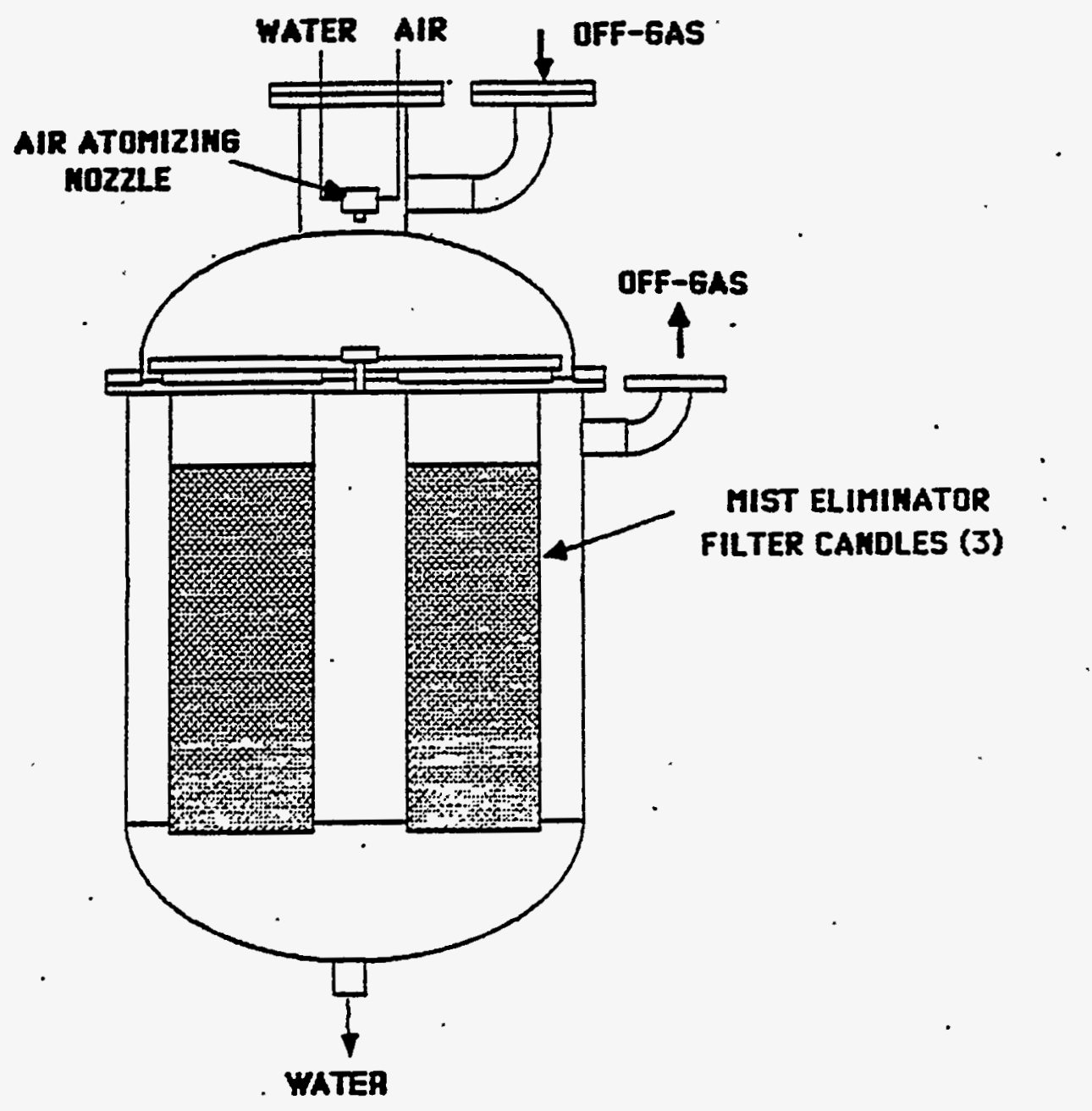

FIGURE 27. High-Efficiency Mist Eliminator 
fiber bed) is prevented by control of the water and off-gas flow raites. Excess water flows from the HEME to the SBS by gravity flow. A failure rate of 9000 hours is assumed for the HEME and 4 batches of 40 liters (10.57 gallons) each is assumed to be required to decontaminate the item for repair or disposal.

Heater. In order to protect the roughing/HEPA filters that "polish" the off-gases prior to emission, the off-gases are heated to reduce the potential - for condensation (see Figure 28). Heaters are relatively passive itiems with the heating elements generaliy the limiting component. An average failure

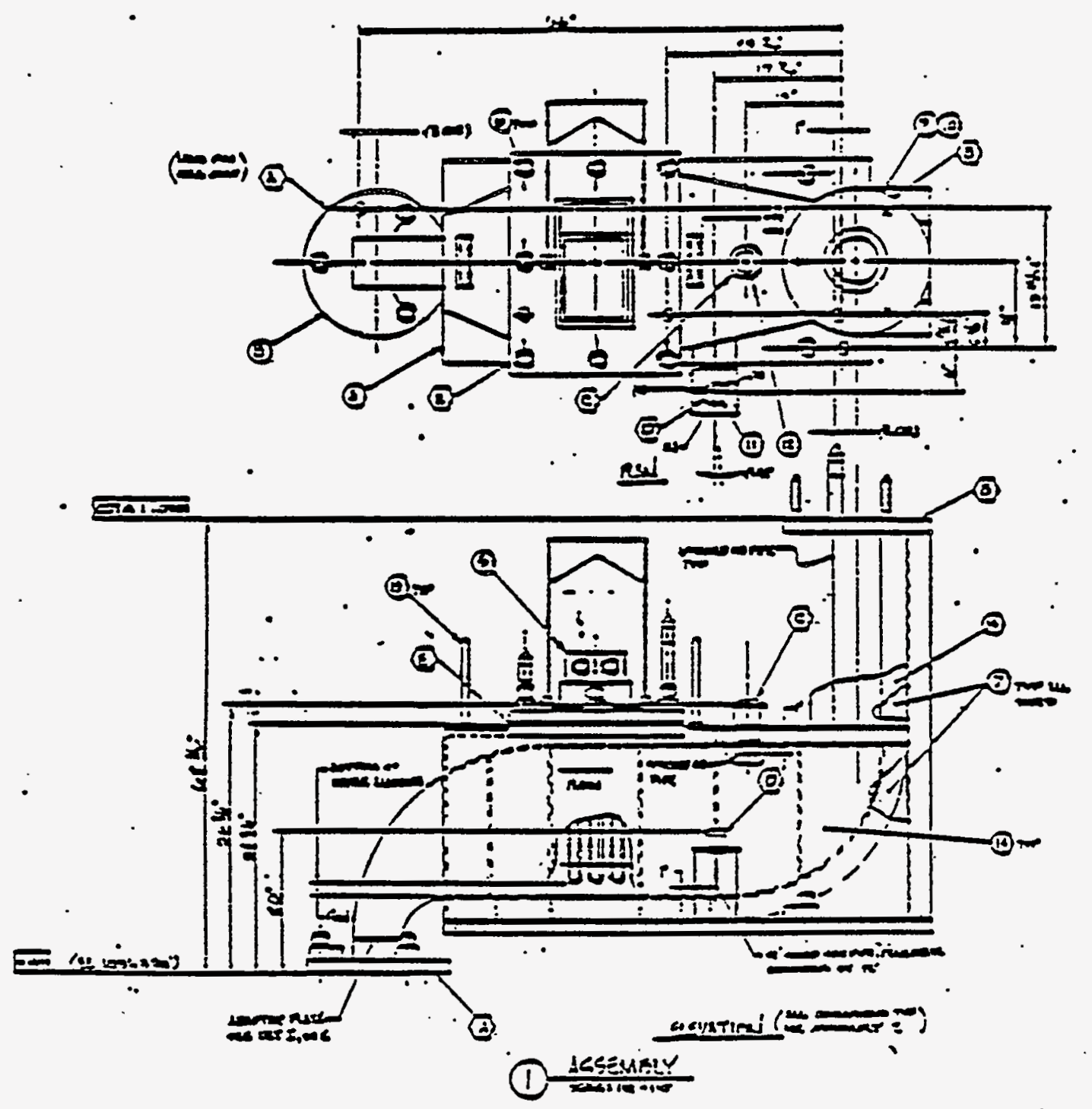

FIGURE 28. Filter Preheater 
rate of 18,000 hours is assumed and 4 batches of 40 liters (10.57 gallons) each are required to decontaminate the item for repair or disposal.

Roughing/HEPA Filters. Filters are passive items with the blower providing the motive force to pull off-gases through the equipment. The filters are encased in a metal package to allow remote handling (see figure 29). The failure of the item generally occur due to loading of the filter media resulting in excessive pressure differential across the filters. An average - failure rate of 9000 hours is assumed (a compromise between the $>100,000$ hours in IEEE 1984 and lower values reported el sewhere) with no decontamination prior to disposal.

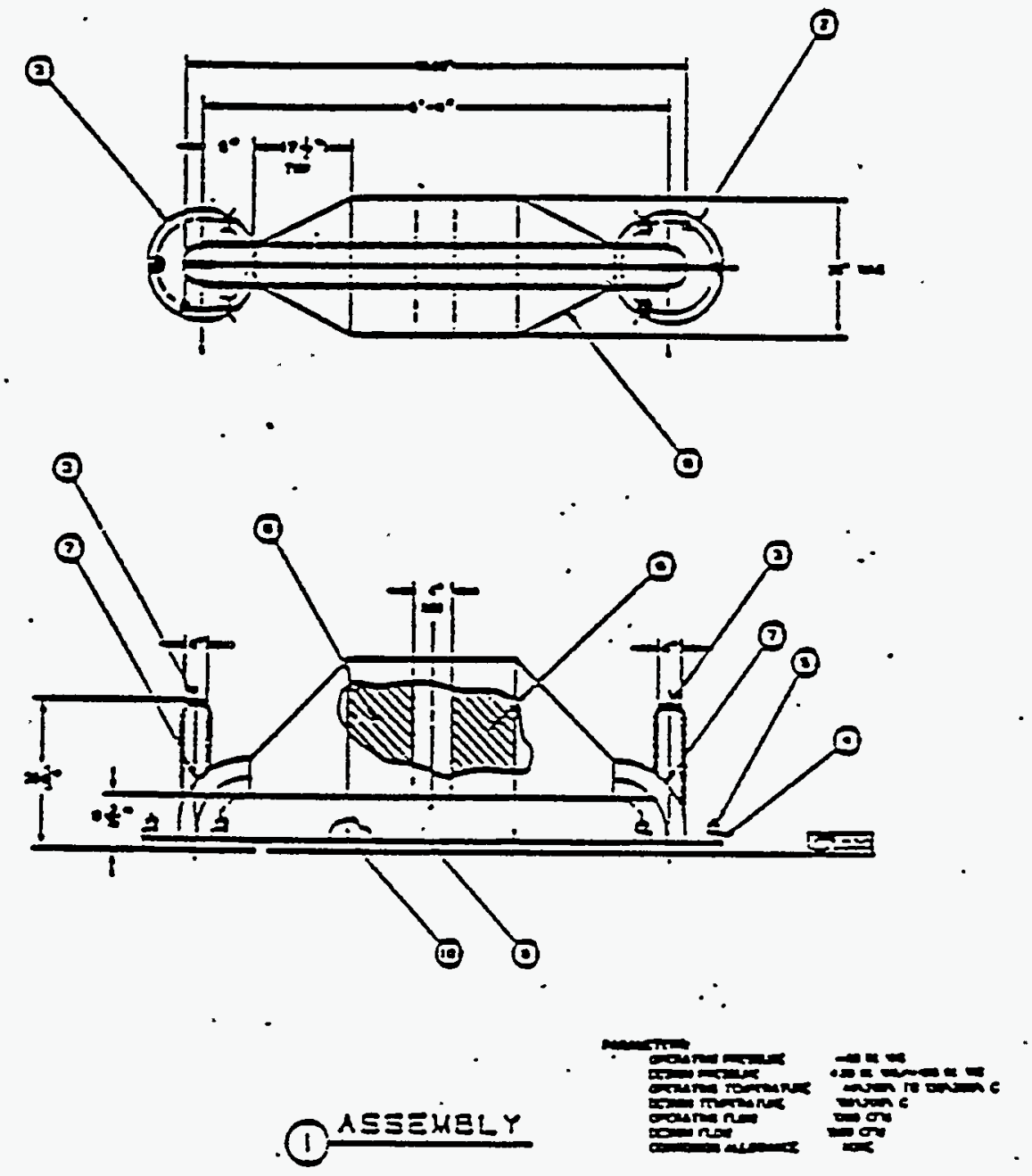

FIGURE 29. Off-Gas HEPA Fi7ter 
Blower. Blowers are mechanical items like pumps. Hear, loss of seals and $g l$ ands, etc., can result in degraded performance or faj7ure. An average failure rate of 25,000 hours is assumed with no decontamination prior to disposal (the blower is the last item in the off-gas treatment system and is not considered to be highly contaminated).

Pumps-I (Intermittent Service). Pumps are mechanical items that can wear with service. A fallure rate of 4,000 hours is assumed. Pumps are used on the SBS for intermittent transfer of liquids and for sampling. It is assumed that these pumps are used for 1 hour each day and the failure rate per day is 4000 hours $\times 24=96,000$ hours. It is further assumed that 3 batches of 40 1iter ( 10.57 gallons) each are required to decontaminate a pump prior to repair or disposal.

\section{Process Vessel Vent System (HWVP)}

The individual items of equipment used are the same as for the melter off-gas treatment system except that no HEME is used. The SBS has 2 pump-Is for liquid transfer and sampling. The system provides surge capacity for the melter off-gas system but should not see as rigorous conditions. The failure rate assumed for all items except the blower are one-half the rate for melter off-gas service. The steam condensation rate for the PVV SBS is approximately $20 \mathrm{lb} /$ hour and would contribute to the low-level liquid wastes from. the system.

\section{Melter Off-Gas System B}

\section{Film Cooler. Same as for System A:}

Quencher. The quencher is a large-scale jet pump whose function is to cool the off-gases. Water is pumped from the OGCT and contacted with the off-gases prior to entry into the OGCT. It is assumed that $100 \mathrm{lb} /$ hour of steam are condensed and drained into the OGCT. The quencher itself is a passive item but the pump average failure rate is assume to be 4,000 hours. It is assumed that 2 batches of 40 1iter ( 10.57 gallons) each of decontamination solution are required prior to repair or disposal of this item.

Off-Gas Condensate Tank. The OGCT is a large collection tank (11,000 gallons) receiving condensate from the quencher, the SAS, the OGC and the HEME. It supplies water (cooling coil to closed loop chilled water system) 
to the quencher and the SAS. The OGCT is agitated by a motor-driven stirrer. Pumps are used to transfer liquids to the SAS and condenser; excess condensate is transferred to the recycle collection tank (RCT) and samples are provided. The OGCT is assumed to receive $880 \mathrm{lb} /$ hour (110 gallons/ hour) of low-level liquid effluent from all sources. The average failure rate for a process vessel is assumed to be 350,000 hours. The c00ling coil-chiller failure rate is approximately the same. It is assumed that 10 batches of 40 liters (10.57 gallons) each of decontamination solution are needed to clean the vessel before repair or disposal.

Steam-Atomized Scrubber. . The SAS is two-stage; a single stage is shown in Figure 30. Water from the OGCT is atomized with supplied steam and mixed with the OGCT off-gases in a horizontal mixing tube to wet and promote coalescence of particulate materials in the off-gases. Particulate materials are removed from the off-gases by a cyclone separator and the condensates returned to the OGCT. The off-gases pass to the OGC. It is assumed that $660 \mathrm{lb} /$ hour of steam are condensed in the SAS. The average fai7ure rate is assumed to be 9,000 hours and 1 batch of 40 1iters ( 10.57 gallons) of decontamination solution is required for cleanup prior to repair or disposal.

Condenser. The condenser is a she11 and tube heat exchanger using chilled water from a closed loop system that removes condensibles in the offgas stream and is primarily present for mercury removal. Since mercury is not of concern in the HWVP, this item is not considered in this evaluation.

High-Efficiency Mist Eliminator. The basic function and operation of the HEME is the same as described above. The HEME filter proposed for the DHPF (see Figure 31) uses three smaller, cylindrical, packed fiber beds generally similar to those proposed for HWVP and WVDP. Off-gases enter into a central plenum located at the top, hemispherical portion of the vessel. A water spray introduces water droplets into the off-gases at this location. The wetted off-gases and water droplets are drawn into the central annulus of the candles and the water droplets serve the same purpose as in the HWVP and WVDP HEME. Under these conditions, it appears that wicking could result. If wicking does occur, forcing the operation of the HEME in a dry mode, the failure rate for this configuration of HEME filters could be substantially higher than for those operated with water flow. An increase in the failure 


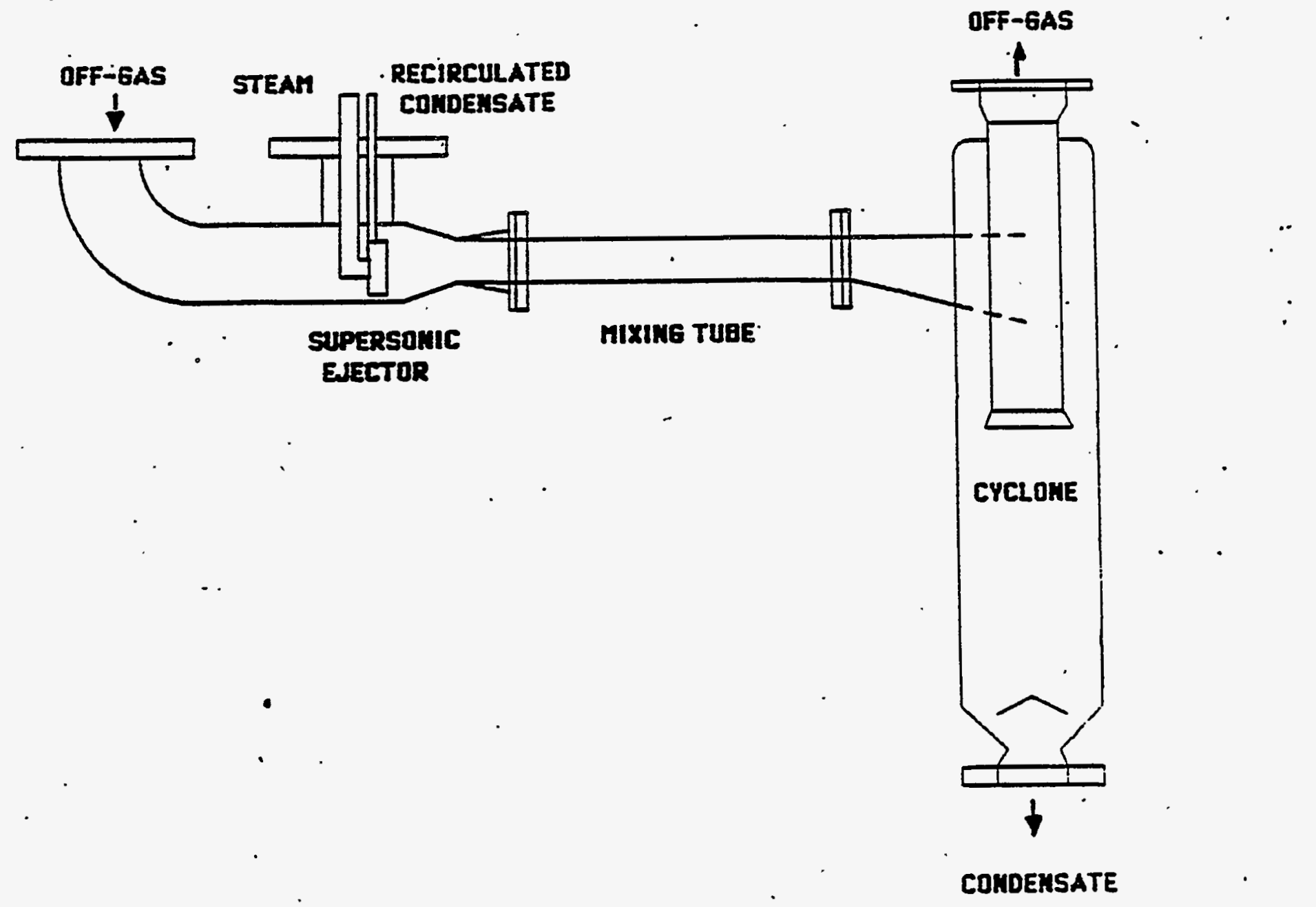

\section{EIGURE 30. Steam-Atomized Scrubber}

rate aT.so results in a higher decontamination solution usage rate. For the purposes of this evaluation, the same failure rate and decontamination requirements are assumed for both types of HEMEs.

- Heater. Same as for System A.

Roughing HEPA Filters. Same as for System A.

B7ower. Same as for System A.

Pump-C (Continuous Service). (See System A for description of pumps.) The failure rate is assumed to be 4000 hours and 3 batches ( 40 liters or 10.57 gallons per batch) are required to decontaminate the item prior to 


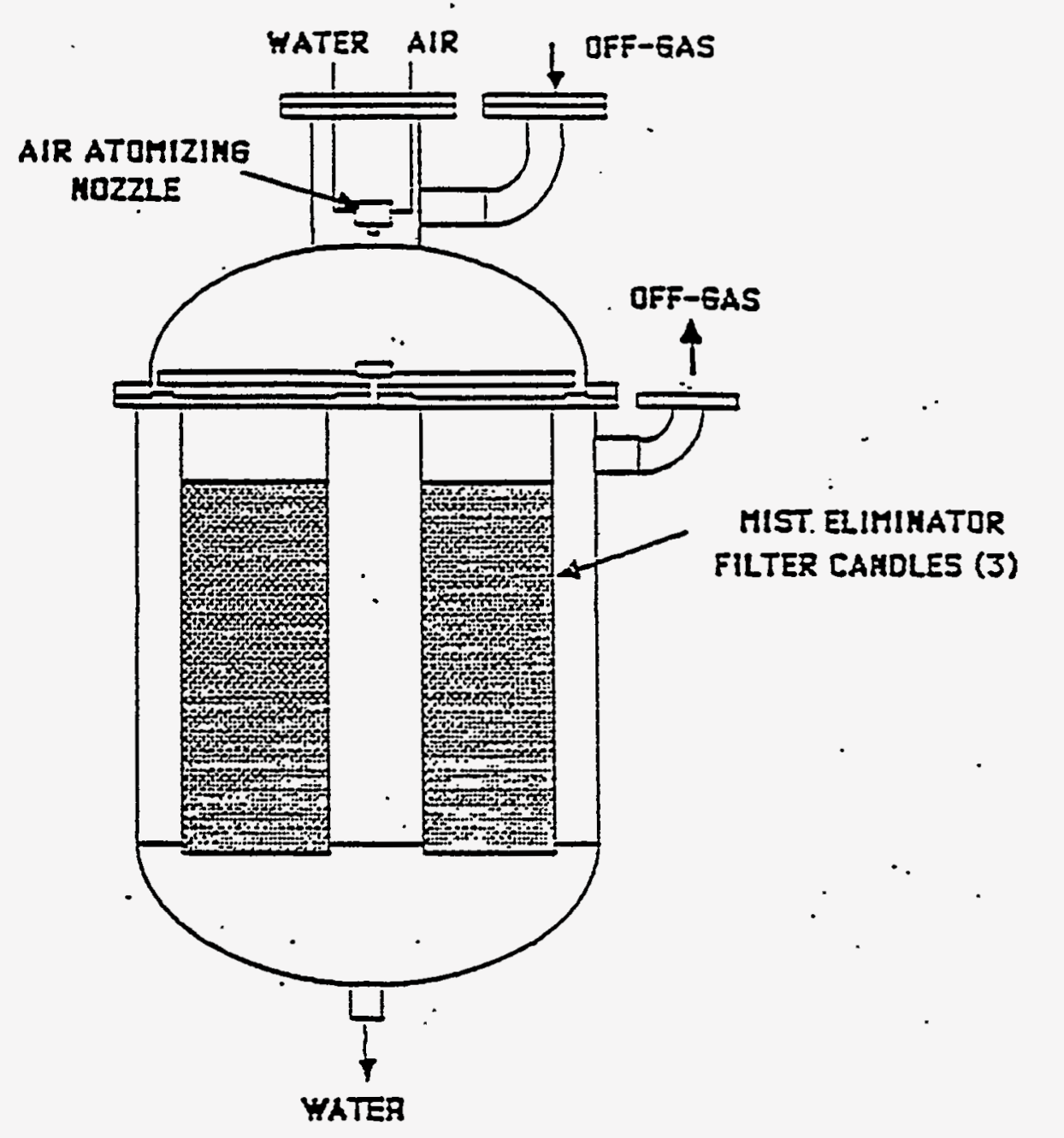

FIGURE 31. DWPF High-Efficiency Mist Eliminator

repair or disposal. Three pump-Cs are used on the OGCT: for the quencher, SAS and HEME. Two pump-Is are used on the OGCT: for liquid transfers and sampling.

\section{Process Vesse] Vent System}

\section{Process Vessel Vent:}

The PVV for System B is a completely separate system. The following descriptions are for the individual items of equipment.

Formic Acid Vent Condenser (FAVC). The FAVC is a single-pass shell and tube heat exchanger. Chilled water $\left(10^{\circ} \mathrm{C}\right)$ is circulated through the shell. The chilled air is passed through a HEME located in the center of the vessel. 
The HEME is normally. operated dry, but a high-pressure water spray is provided to rinse material from the HEME as required (see Figure 32). The FAVC's primary function is the removal of organics and mercury, neither of concern to the HWVP. This item is not considered in the evaluation.

Heater. Same as for System A.

Process Vessel Vent Filter. The process vessel vent filter is a graded density, packed fiber-glass bed (see Figure 33). The filter consists of an outer tank with two internal, packed fiber-glass beds in parallel.. The inlet vapor stream inlets in the middle of the vessel between the two beds and the flow splits between the parallel beds. The lower four beds are bulk 115-K Fiberglass supported by screen welded to the vessel. The bed-packing densities range from 0.75 to $5.0 \mathrm{lb} / \mathrm{cu} \mathrm{ft}$. The final bed is a 1-inch-thick. layer of AA Microlite Fiberglass. Again, the device is passive: off-gas is drawn through the filter by differential pressure generated by the downstream blowers. The filter is sensitive to increased pressure drop across the filter from the accumulation of particulate material on/in the packed bed or. additional packing of the fiber glass during operation. The filter could suffer the loss of function from bypasses resulting from the separation of the bed from its frame, separation of the bed supports from the vessel, or corrosion of the inlet piping. Under the proper conditions, corrosion of the filter material itself could result but does not appear to be a serious problem for the use considered here. .

It does not appear that the service should be as demanding as for the filters used in the melter off-gas system. The failure rate assumed for similar items is $\mathbf{4 5 0 0}$ hours. How much longer the process vessel vent filter could remain in service is dependent upon some of the factors 7 isted above. A demister, proposed for use in the DWPF process vessel vent, was assumed to have an average failure rate of 9,000 hours. For the sake of conservatism, an average failure rate of 9,000 hours is assumed for the process vessel vent filter for this study. It is assumed that 5 batches (40 liters/batch or 10.57 galions each) of decontamination solution are required to clean this item prior to repair or disposal. 


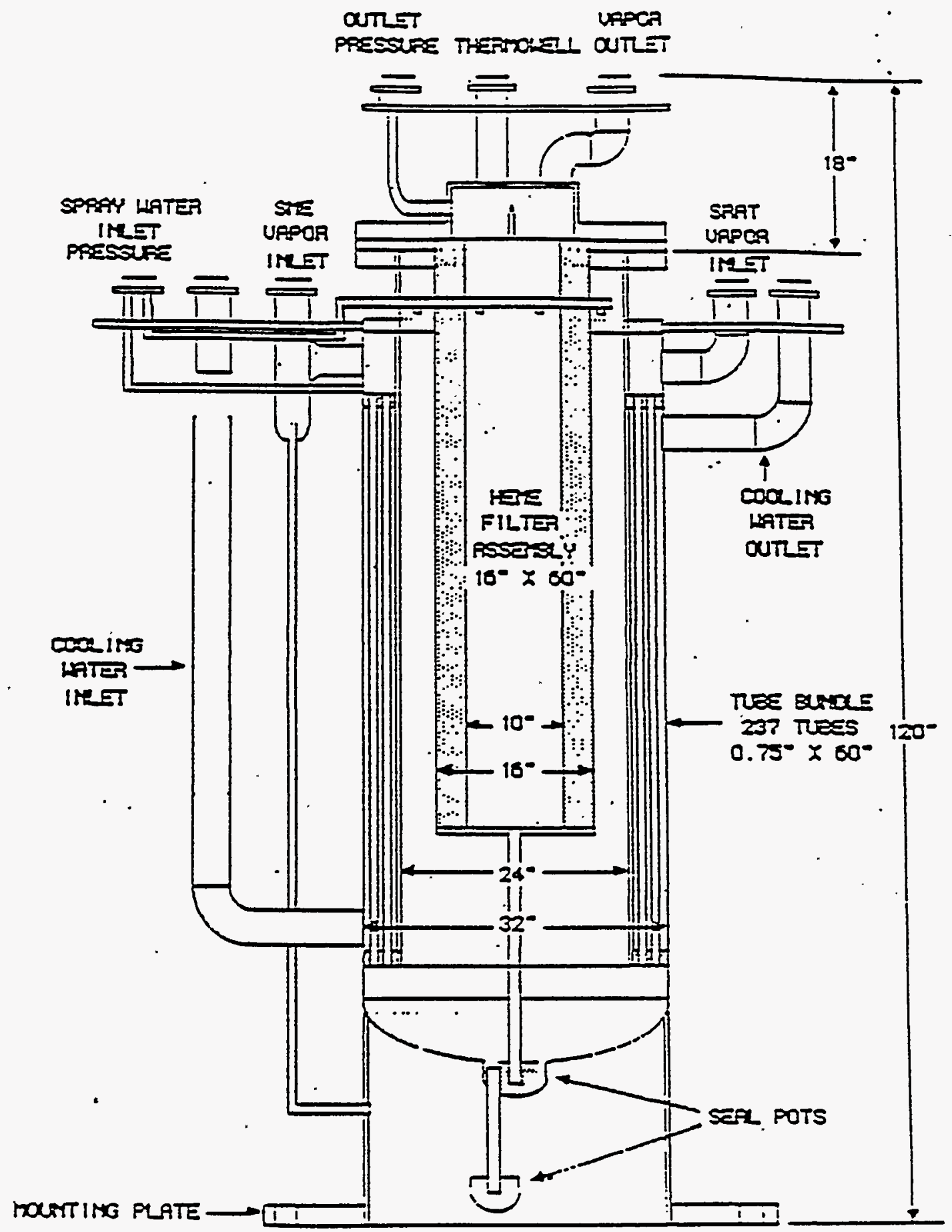

FIGURE 32. DWPF Formic Acid Vent Condenser 


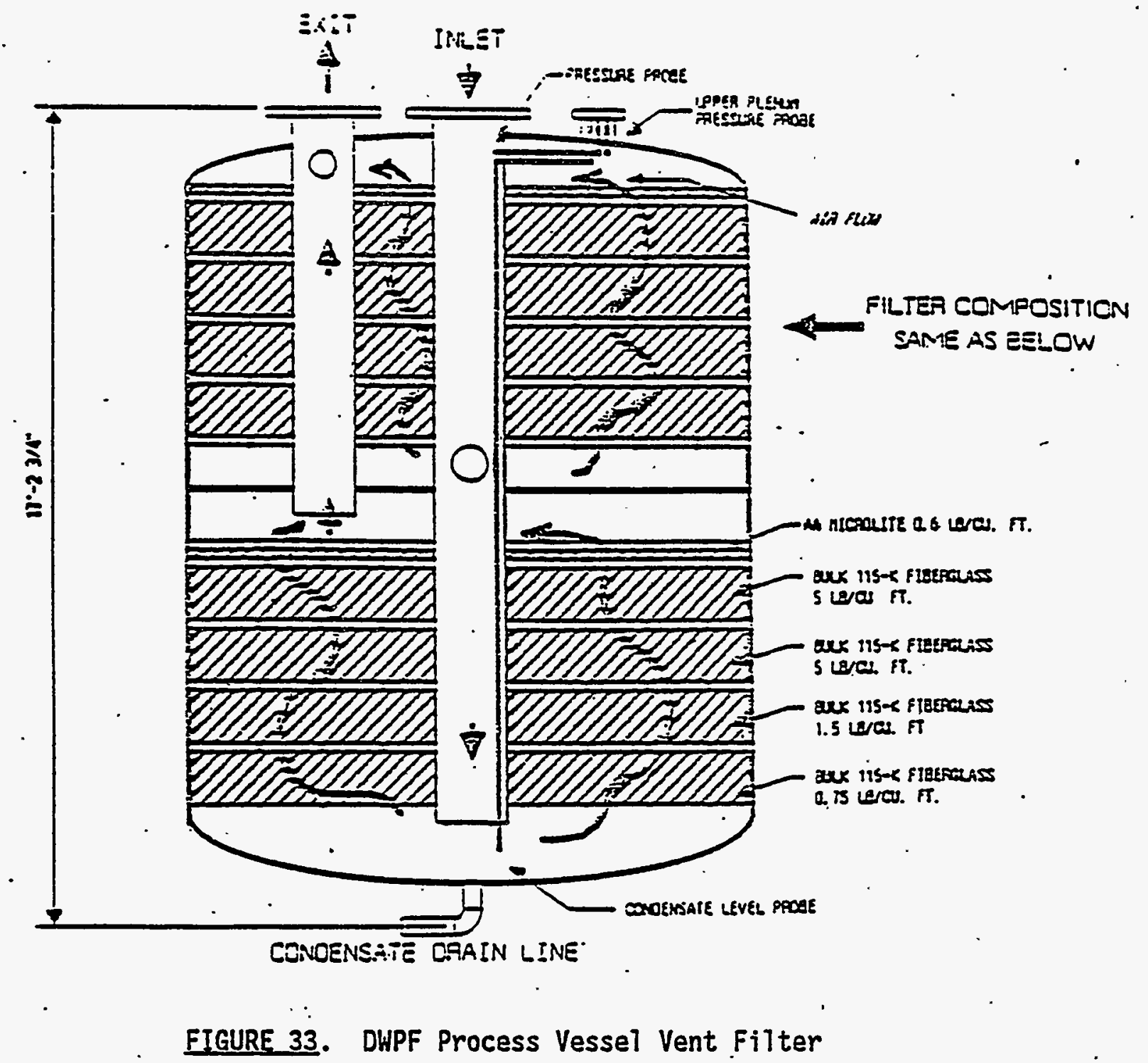

Blower. Same as for System A.

Pump-1. A pump is required for intermittent transfer of accumilated lịquid from the process vessel vent filter. See System A description.

\section{SECONDARY WASTE GENERATION}

The basic sources of secondary waste were given in the Introduction. The melter off-gas system processes are conducted remotely in cells. Under normal processing conditions, the secondary solid wastes generated from operation of the off-gas systems will be minimal (trash with potential contamination from the operating areas, contaminated clothing) and associated with 
incidental operations conducted by the operating personnel. Anticontamination clothing for large facilities is usually washed and reused. This resuits in some unknown quantity of contaminated waste liquid for the laundry and some solid waste from clothing that cannot be decontaminated satisfactorily. If the anticontamination clothing is single use (paper/plastic that is discarded after each use), the quantity of secondary waste could increase significantiy depending upon the number of people entering the operating areas. The quantity will depend upon the size of the operating force and to some lesser extent upon the number of visitors. The size of the operating force in the three proposed processes has not been finalized for these operations. The number is assumed to be dependent upon the degree of manuat operations performed rather than the throughput since the process is remote and automated. Thus, assuming all three processes use the same type of handling for anticontamination clothing, the amount of solid waste from this source during routine operations will be similar.

The major differences in the solid and Tiquid wastes generated by the two melter off-gas systems are expected to be in the secondary waste generated by. off-gas system equipment failures, the liquid wastes from equipment decontamination and process liquid effluents from the condensation of moisture in the off-gas. Each failure would require the following:

- flushing of the piping and equipment to provide some level of decontamination to allow examination of the equipment (7iquid waste)

- transfer to the remote decontamination cell for additional flushing of those items that are to be disposed (Tiquid waste) and burial of the piping or equipment and dunnage in a specially constructed box (solid waste)

- transfer and flushing in the remote decontamination cell and additional flushing and repair in the contact decontamination and maintenance cell (1iquid waste) for those item that can be repaired. An item that must be replaced on the equipment would require burial (solid waste)

- in-cel1 decontamination for those instances where equipment or piping failures resulted in contamination of the cell (liquid waste).

Only the impact of equipment failures are covered here.

Equipment Failure Rates. Equipment failure rates for some equipment initially proposed for the HWVP have been estimated (Fort 1987, Fi.sher et a?. 
1986, IEEE 1984). The faiture rates assumed for this study are shown in Table 16. The number of each item used in the process is also listed.

Estimates of Solid Waste Generation by the Melter Off-Gas Systems. The weight of solid waste that could be generated by each proposed off-gas treatment systen is shawn in Table 17. The calculations are based on the number of each item, its failure rate and its weight. For the purposes of this analysis, it is assumed that

- The processes operate 24 hours/day, 365 days/year (8760 hours/year).

- One in three failures resuits in disposal of the item (repair-todisposal ratio of $2: 1$ ).

- The weights listed are representative of the items that will actually be used.

Since the process and equipment design is not final, the values for failure rates and weights assumed are based upon the surveys of similar items, estimates based on the experience of individuals that developed the equipment or have had experience with similar items of equipment. Without a specific design, the failure rates cannot evaluate the various features that will differentiate between similar items used in different processes. For the purposes of this analysis, a filter was considered a filter without consideration of design features that may better adapt a specific design than others.

The lack of consideration for design features and specific design also impacts the liquid waste generation. . Estimates were made as to the number of batches of decontamination solution required to decontaminate items of equipment after failure. The values are only based upon the estimates of approximate square feet of surface that the items may contain and does not consider the complexities or ease of decontamination based on the design of the specific items of equipment. 
TABLE 16. Off-Gas Equipment Failure Rate

$\operatorname{MTBF}(a)$

Hours Number

- System A - Melter Off-Gas

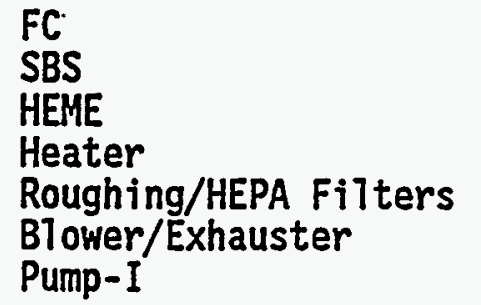

-Process Vessel Vent

FC.

SBS

Heater

HEPA

Blower

Pump-I

$\begin{array}{rr}9,000 & 1 \\ 300,000 & 1 \\ 9,000 & \cdot 1 \\ 18,000 & 1 \\ 9,000 & 1 \\ 25,000 & -1 \\ 96,000 & 2\end{array}$

18,000

600,000

36,000

18,000

25,000

96,000

$$
\begin{aligned}
& 1 \\
& 1 \\
& 1 \\
& 1 \\
& 1 \\
& 2
\end{aligned}
$$

- System B - Melter Off-Gas

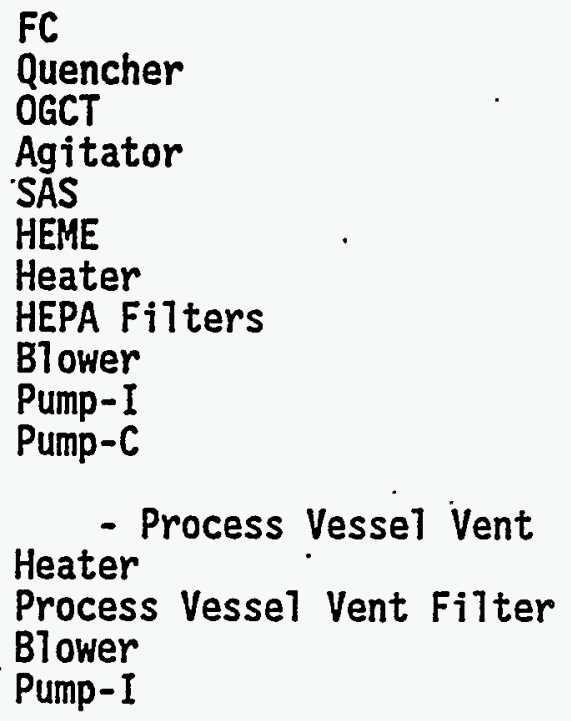

(a) MTBF - Mean time between failure = failure rate. 
TABLE 17: Solid Waste Disposal

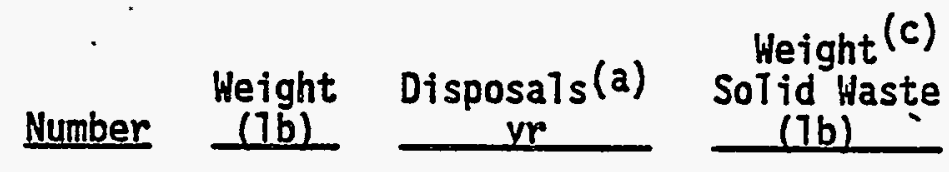

- System A - Melter Off-Gas

$\begin{array}{lrrrr}\text { FC } & 1 & 300 & 0.32 & 97 \\ \text { SBS } & 1 & 46,400 & 0.01 & 452 \\ \text { HEME } & 1 & 21,000 & 0.32 & 6,813 \\ \text { Heater } & 1 & 1,500 & 0.16 & 243 \\ \text { HEPA(b) } & 1 & 1800 & 0.97 & 1,460 \\ \text { Blower } & 1 & 3,000 & 0.12 & 360 \\ \text { Pump-I } & 2 & 1,000 & 0.03 & 60\end{array}$

- Process Vessel Vent

FC

SBS

Heater,

Blower

Pump-I

$\begin{array}{rr}1 & 300 \\ 1 & 46,400 \\ 1 & 1,000 \\ 1 & 800 \\ 1 & 3,000 \\ 2 & 1,000\end{array}$

0.16

0.005

48

0.08

0.49

122

730

0.12

183

0.03

60

- System B - Melter Off-Gas

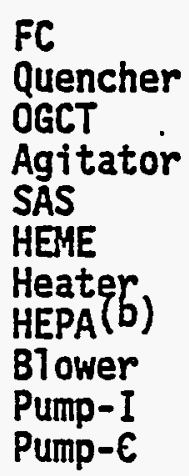

- Process Vessel Vent

Heater

PVV Filter(b)

Blower

Pump-I

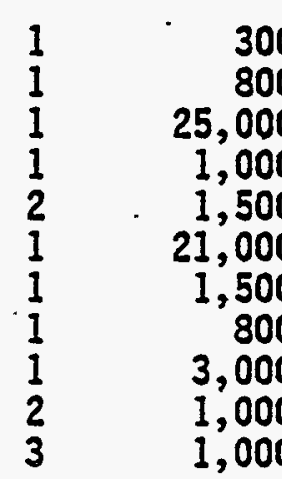

300

800

0.32

0.01

0.01

10.10

0.65

0.32

0.16

0.97

0.12

0.03

2.19

97

8
209

97

973

6,813

243

1,460

360

60

2,190

\section{3
3
0
0
0}


Estimates of the weight of solid waste generated by the two waste treatment systems due to equipment failures for the melter off-gas systems is are listed below. The total estimated weight of solids wastes for each components are:

$$
\begin{aligned}
& \text { System A - Melter Off-Gas: } \quad 9,485 \mathrm{lb} \\
& \text { - Process Vessel Vent: 1,369 1b } \\
& \text { Total . 10,854 ib } \\
& \text { System B - Melter Off-Gas: } \quad 12,510 \mathrm{~Tb} \\
& \text { - Process Vessel Vent: } 7,148 \mathrm{~Tb} \\
& \text { Total } \\
& 19,658 \mathrm{lb}
\end{aligned}
$$

Estimates of Liquid Haste Generation from Melter off-Gas Processes. The volume of liquid waste generated by each melter off-gas system is the sum of the liquid waste generated from the decontamination of failed equipment and the moisture condensed from the off-gases by the treatment equipment.

The volume of decontamination solution used per year was calculated by the number of failures of each item per year multiplied by the number of batches of decontamination solution required multiplied by the volume of liquid per batch. The results are tabulated in Table 18.

The quantity of liquid effluent generated by the condensation of moisture was calculated in the "Energy Analysis" section of this report. The total pounds of steam condensed divided by $8 \mathrm{~Tb} / \mathrm{gall}$ on was used to convert the weight into volume. The treatment process for the liquid effluent and the associated energy costs are also discussed in the "Energy Analysis" section. The total volume of waste from decontamination solution and condensed steam is shown in Table 19. 
TABLE 18. Off-Gas Equipment Decontamination Volumes

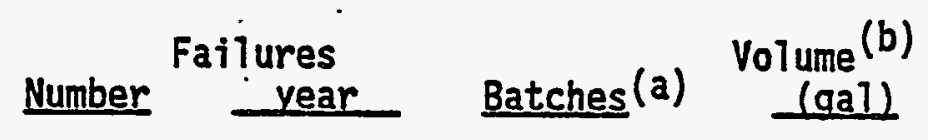

- System A - Melter Off-Gas

FC
SBS
HEME
Heater
HEPA(C)
Blower(d)
Pump-I

$\begin{array}{ll}1 & 0.97 \\ 1 & 0.03 \\ 1 & 0.97 \\ 1 & 0.49 \\ 1 & 0.49 \\ 1 & 0.35 \\ 2 & 0.18\end{array}$

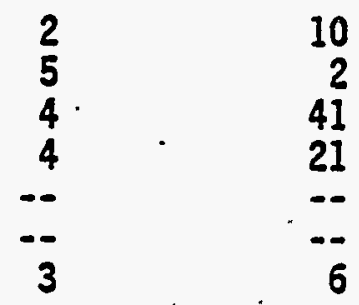

- Process Vessel Vent

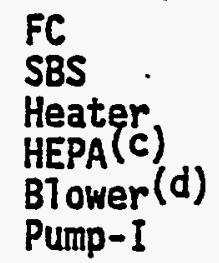

- System B - Melter Off-Gas

FC
Quencher
OGCT
Agitator
SAS
HEME
Heater
HEPA(c)
Blower (d)
Pump-I
Pump-C

$\begin{array}{ll}1 & 0.97 \\ 1 & 0.03 \\ 1 & 0.03 \\ 1 & 0.29 \\ 2 & 1.95 \\ 1 & 0.97 \\ 1 & 0.49 \\ 1 & 0.97 \\ 1 & 0.35 \\ 2 & 0.18 \\ 3 & 6.57\end{array}$

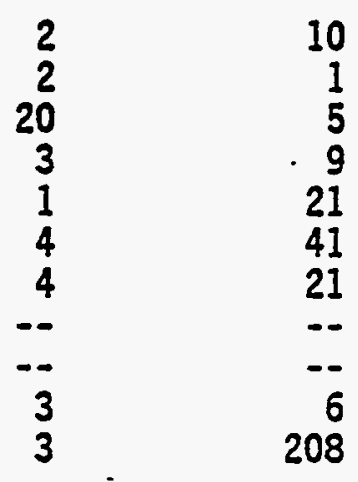

$\because$ Process Vessel.Vent
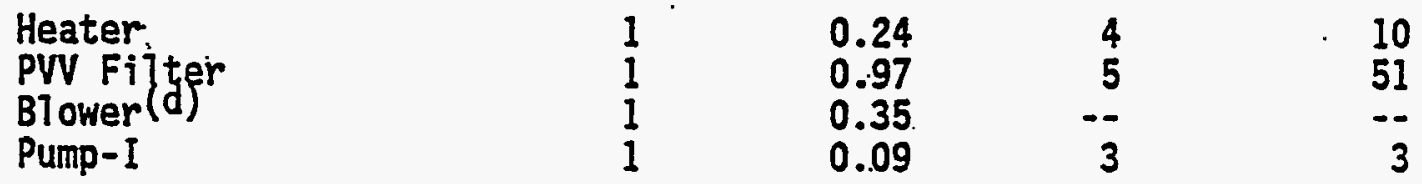

(a). Batches of decontamination solution (40 liters, 10.57. gallons) required per failure.

(b) Volume of decontamination waste generated per year.

(c) Roughing/HEPA fijters are not assumed to be decontaminated prior to disposal.

(d) Blowers are the last item of equipment on the off-gas treatment train and are assumed to be sufficiently low in contamination to allow handling without decontamination. 
TABLE 19. Annual Volume of Liquid Waste Generated by Off-Gas Treatment Systems

\begin{tabular}{cc}
$\begin{array}{c}\text { Decon Solution } \\
\text { (gal) }\end{array}$ & $\frac{\text { Process Effluent(a) }}{\text { (gal) }}$ \\
\hline 80 & 112,000 \\
22 & 22,000 \\
322 & 964,000 \\
64 & 66,000
\end{tabular}

(a) Gallons of process effluent generated by the condensation of steam introduced into the process based upon energy analysis. Assumes $8 \mathrm{lb} / \mathrm{gal}$ of water. 



\section{OFF-GAS SYSTEMS ENERGY ANALYSIS}

The energy required to operate the melter and vessel ventilation off-gas systems for the HWVP, DWPF, and WVDP has been estimated. Because of differences in the normal operating capacities and melter feed compositions, direct comparisons of the energy requirements of each system, operating at design conditions, would be inappropriate. Consequentiy, to provide for a normalized comparison, the HHVP off-gas source terms from the melter and vessel ventilation system were used as the source terms for the DWPF and WVDP. off-gas systems. The energy analysis is therefore based upon the energy required to process a set quantity and composition of off-gas.

To calculate the energy requirements for the HWVP, documented flowsheet temperatures and flow rates were used when available. Because of the similarities in the processes, the temperatures and flow rates from the HWVP melter off-gas (MOG) system were used to evaluate the components in the WVDP MOG. Temperatures and flow rates were assigned to the DHPF off-gas system components based upon the normal operating conditions of functionaliy equivalent HHVP equipment.

The MOG systems for the HWVP and WVDP are nearly identical and utilize similar equipment. Therefore, it is expected that the energy requirements of the systems wi11 be approximately equivalent. Although the configuration of the vessel ventilation systems differ, the dissimilarities do not result in a significant difference in the overall energy requirements of the WVDP and the HWVP off-gas systems.

At DWPF, an ejector-venturi quencher is used to perform a function similar to that of the submerged bed scrubbers (SBSs) at the HWVP and the WVDP. Additionally, two steam atomized scrubbers (SASs) are employed within the DWPF MOG system to remove submicron aerosols. The HWVP and the WVDP MOG systems do use SAS technology. Both the venturi quencher and the SASs require the continuously operating pumps to supply water for quenching and scrubbing the off-gas. Furthermore, the SASs will also use a significant quantity of steam. Because of these differences in the quenching and scrubbing systems, operation of the DWPF off-gas system will require more energy than the HWVP and the WVDP. 
Table 20 summarizes the results of the energy analysis and provides information on the energy costs. The assumptions and bases used to generate. the data in the table have been included in Appendix B. Data from Table 20 indicate that the DWPF off-gas system will require more energy, and be approximately eight times more expensive to operate than the HWVP and the WVDP off-gas systems. The difference in energy consumption and energy costs between the HWVP and the WVDP are insignificant.

TABLE 20. Off-Gas Systems Energy Requirements and Energy Costs

\begin{tabular}{|c|c|c|c|}
\hline \multirow{3}{*}{$\begin{array}{l}\text { Cooling--with process } \\
\text { cooling water, BTU/h(a) } \\
\text { (annual cost, } \$ / y r)(a)\end{array}$} & HWUP & DWPF & WVDP \\
\hline & 240,000 & $1,200,000$ & 250,000 \\
\hline & $(1,400)$ & $(7,100)$ & $(1,500)$ \\
\hline $\begin{array}{l}\text { Heating, BTU/h } \\
\text { (annual cost, } \$ / y r)(a)\end{array}$ & $\begin{array}{r}21,000 \\
(1,100)\end{array}$ & $\begin{array}{r}20,000 \\
(1,100)\end{array}$ & $\begin{array}{r}20,000 \\
(1,100)\end{array}$ \\
\hline \multirow{2}{*}{$\begin{array}{l}\text { Steam--for SASs, } \\
\text { Ib/h } \\
\text { (annual cost, } \$ / y r)(a)\end{array}$} & 0 & 800 & 0 \\
\hline & 0 & $(38,000)$ & 0 \\
\hline $\begin{array}{l}\text { Blower Power, hp } \\
\text { (annual cost, } s / y r) \text { (a) }\end{array}$ & $\begin{array}{c}17 \\
(2,200)\end{array}$ & $(1,200)$ & $\begin{array}{r}17 \\
(2,200)\end{array}$ \\
\hline $\begin{array}{l}\text { Pump (b) Power, hp } \\
\text { (annual cost, } \$ / y r \text { ) (a) }\end{array}$ & 0 & $\begin{array}{c}.6 \\
(780)\end{array}$ & 0 \\
\hline $\begin{array}{l}\text { Energy for Liquid } \\
\text { Haste Processing } \\
\text { Steam, } 7 \mathrm{~b} / \mathrm{yr} \\
\text { (annual cost, } \$ / \mathrm{yr}) \text { (a) }\end{array}$ & $\begin{array}{r}250 \\
(12,000)\end{array}$ & $\begin{array}{r}2,000 \\
(97 ., 000)\end{array}$ & $(13,000)$ \\
\hline $\begin{array}{l}\text { Cool ing, BTU/h } \\
\text { (annual cost, } \$ / . y r)(a)\end{array}$ & $\begin{array}{l}240,000 \\
(480)\end{array}$ & $\begin{array}{l}1,900,000 \\
(3,800)\end{array}$ & $\begin{array}{r}260,000 \\
(520)\end{array}$ \\
\hline otal En & $(17,000)$ & $(150,000)$ & $(18,000)$ \\
\hline
\end{tabular}

(a) Annual cost based on $70 \%$ operational availability--6,100 h/yr.

(b) Continuously operating pumps are required to supply water to venturi quencher and SASs. 
The primary reason that DWPF off-gas system will be approximately eight times more expensive to operate than the other two systems is the use of substantial quantities of steam in the SASs. First, significant quantities of energy must be expended to generate the steam. After the steam is injected into the off-gas, it must be cooled, condensed, and removed. The condensed steam from the SASs and the meiter, which will be contaminated with radioactive and chemical constituents, must be treated and processed (discussed below).. Another contributing factor to. the larger energy consumption rate of DWPF is the use of continuously operating pumps for the venturi quencher and the SASs. Approximately 80 and $40 \mathrm{gpm}$ of water will be used in the quencher and the SASs, respectively, to cool and scrub the melter off-gas.

The HWVP and the WVDP off-gas systems wi11 use SBSs to cool and scrub melter off-gas. Steam generated in the melter will accumulate in the SBSs; however, no additional steam will be introduced into the off-gas systems under normal operating conditions. Furthermore, no continuously operating pumps are required for the SBSs.

From Table 20, it is apparent that the majority of off-gas system energy costs are associated with the processing of contaminated waste water. These relatively high costs will be incurred because waste water processing includes energy-intensive operations. Steam and water vapor will condense from the off-gas streams and accumulate in the SBSs (or in the OGCT at the DWPF). The accumulated waste liquid will be transferred in batches to a decontamination waste treatment tank (DWTT). For the purposes of the energy analysis, it has been assumed that the waste water in the DWTT will be heated and evaporated, and then the vapor will be condensed and cooled. Next, the cooled waste water will be transferred from the DWTT to an evaporator where 90\% of it wi11 again be evaporated and then condensed and cooled. The cooled evaporator condensate, from which most contaminants will have been removed, will be discarded. The fraction of the waste in which the contaminants wi11 be concentrated, will eventually be used as grout make-up water. In summary, the processing of accumulated waste water will include two evaporation and two condensation operations. Therefore, for each pound of waste water 
processed, approximateiy 2 pounds of process steam and 5 gallons of cooling water will be required.

The blower power necessary to maintain a vacuum on the off-gas systems is dependent upon the system components. Table 20 indicates that significantly more blower power will be required by the HWVP and the WVDP than by DWPF. The HWVP and the WVDP off-gas systems will incur pressure drops of approximately 36 inches (H.C.) when the off-gas passes through the SBSs. Less blower power will be required at the DWPF, since a venturi quencher and SASs will be used. For the energy analysis it has been assumed that no pressure drops will be experienced with the quencher or SASs. In the actual. operation of the DWPF off-gas system, vacuum increases (negative pressure drops) may be observed as the off-gas passes through these two units.

\section{MASS AND ENERGY BALANCES}

The energy requirements, flow rates, temperatures and pressures calculated for the off-gas system components of the HWVP ACD, the DWPF and the WVDP are summarized in Tabie 21. The assumptions and bases used to support the calculations from which the data in Table 21 were generated are found in Appendix B. 
TABLE 21. Summary of Mass and Energy Balances for Melter Off-Gas Systems

\section{Component}

- Melter Off-Gas System

Melter Off-Gas

flow rate, $1 \mathrm{~b} / \mathrm{h}$

incondensable

(condensable)

temp., $F$

pres., psia

Film Cooler

Pressure

Control Air

Submerged-Bed

Scrubber

Venturi

Quencher

Off-Gas

Condensate Tank

air, $1 b / h$

air, $1 b / h$

' inlet flow rate, $1 b / h$

- incondensable (condensable)

inlet temp., $F$

outiet temp., $\cdot F$

SBS temp., $-F$

air-inleakage, scfm

pres. drop, in water

cooling, BTU/h

HWVP

DWPF

WVDP

inlet flow rate, $1 \mathrm{~b} / \mathrm{h}$ incondensable

- (condensable)

inlet temp., $\mathrm{F}$.

outlet temp., $\bullet F$

quench water, gpm

water pump, hp

air-inleakage, scfm

cooling, BTU/h

OGCT temp., " $F$

Steam-Atomized

Scrubbers

steam, $1 \mathrm{~b} / \mathrm{h}$

scrub water, gpm

water pump, hp

outlet temp., 'F

390

(160)

750

14.0

700

700

1800

(180)

300

95

95

30

36

210,000

inlet flow rate, $1 \mathrm{~b} / \mathrm{h}$ incondensable (condensabie)

inlet temp., of

outlet temp., of

pres. drop, in. water

cooling, BTU/h
390
$(160)$
750

14.0

390

(160)

750

14.0

700

700

700

700

1800

(180)

300

95

95

30

36

210,000

1800

(180)

300

100

80

4

50

910,000

95

800

36

130

2000

(260)

130

95

10

210,000 
TABLE 21. (contd)

Component

Parameter

HWVP

DHPF

HVDP

Melter Off-Gas System - (contd)

HEME

air-inleakage, scfm

pres. drop, in. Water

3

30

3

30

Pre-Heater

iniet temp., of

for HEPAs

out7et temp., 'F

pres. drop, in. water

heating, BTU/h

93

110

9,600

10,000

20,000

HEPAS

pres. drop, in. water

4

4

4

System Piping

pres. drop, in. water

Blower

flow rate, acfm

intake temp., "F

required vacuum,

in. water

power, hp

4

$4^{\circ}$

4

620

110

620

110

1,300

55

30

110

9

55

17

Vessel Ventilation System (VVS)

SBS

iniet flow rate, $1 \mathrm{~b} / \mathrm{h}$ incondensable

(condensable)

intet temp., - $F$

air-inleakage, scfm

outlet temp., 'F

pres. drop, in. water

cooling, BTU/h.

2,200

(120)

110

30

95

36

26,000
Formic Acid

Vent Condenser

inlet flow rate, $7 \mathrm{~b} / \mathrm{h}$ incondensable (condensable)

inlet temp., -F

outlet temp., 'f

pres. drop, in. water

cooling, BTU/h

inlet flow rate, $7 \mathrm{~b} / \mathrm{h}$

incondensable

(condensable)

inlet temp., $F$

outlet temp., 'F

heating, BTU/h
Pre-Heater

for HEPAS

.

(1)$$
7 b / h
$$$$
F
$$

(n)




\section{TABLE 21. (contd)}

\begin{tabular}{|c|c|c|c|c|}
\hline Component & Parameter & HWVP & DHPF & WVDP \\
\hline \multicolumn{5}{|c|}{ Vessel Ventilation System - (contd) } \\
\hline HEPAs & pres. drop, in. water & 4 & 4 & \\
\hline System Piping & pres. drop, in. water & 4 & 4 & \\
\hline Blower & $\begin{array}{l}\text { inlet flow. rate, acfim } \\
\text { intake temp., ०F } \\
\text { required vacuum, } \\
\text { in. water } \\
\text { power, hp }\end{array}$ & $\begin{array}{r}700 \\
110 \\
50 \\
8\end{array}$ & $\begin{array}{r}600 \\
100 \\
26 \\
4\end{array}$ & \\
\hline \multicolumn{5}{|c|}{ Liquid Waste Processing } \\
\hline Steam & $1 \mathrm{~b} / \mathrm{h}$ & 250 & 2000 & 270 \\
\hline Cooling & $\mathrm{BTU} / \mathrm{h}$ & 240,000 & $1,900,000$ & 260,000 \\
\hline
\end{tabular}





\section{REFERENCES}

Andrews, G. L., and K. C. Rhoads. 1989. Atmospheric Emission Analysis for the Hanford Waste Vitrification Plant. HWVP-1989-IVR00101C, Pacific Northwest Laboratory, Richland, Hashington.

Anon. 1988. "Chapter H. Melter Off-Gas" (pp H-1/Rev. 0-H19/Rev.0) and "Chapter M. Process Vessel Vent" (pp M-1/Rev. 0-M-16/Rev. 0) in DWPF Process and Equipment Description, DPSOP 257-1 (Information Copy), E.I. du Pont de. Nemours \& Company, Inc., Savannah River Plant, Aiken, South Carolina.

Anderson, T. D. 1988. "Section 2.3.6 Melter Off-Gas Treatment (pp 46-64) and Section 2.3.11 Process Vessel Vent System (pp 98-106) in HWVP Process Desian Basis Flow Sheet Document DRAFT, Rev A, Hestinghouse Hanford Company, Richland, Hashington.

Barnes, S. $11 / 23 / 88$ \& 12/12/88. Private communications, Hest Valley Nuclear Services Company, West ValTey, New York.

Brink, J. A. 1964. "Removal of Phosphoric Acid Mists," Chapter 5 in Gas Purification Processes, Part B, Geo. Newnes, Ltd., London.

Bul1, H. 12/12/88. Private communications, Savannah River Plant, Aiken, South Carolina.

Calvert, et al. 1972. Scrubber Handbook Volume I, PB-213-016, National Technical Information Service.

Christian, J. D. and D. T. Pence. 1977. Critical Assessment of Methods for Treating Airborne Effluents from High-Level Waste Solidification Processes. PNL-2486, Pacific Northwest Laboratorr, Rich7and, Hashington.

Colvin, W. P. 1983. Off-Gas System Data Summary for the North Run of the Large Slurry-Fed Melter: DPST-83-809, Savannah River Laboratory, Aiken, South Carotina.

Fisher, F. H., R. B. Grinde, J. C. Lavender and R. A. Sovers. 1986. A Reliability, Availability and Maintainability Analysis of the Hanford Waste Vitrification Plant (HWVP). - HWVP-11041A DRAFT, Pacific Northwest Laboratory, Richland, Washington.

Fort, L. A. July 1987. Letter Report - Hanford Haste Vitrification PIant Decontamination Solution Evaluation. 65651-87-046, Hestinghouse Hanford Company, Richland, Washington.

Goles, R. H., and G. J. Sevigny. 1983a. Off-Gas Characteristics of Defense Haste Vitrification Using Liquid-Fed Ceramic Melters. PNL-4819, Pacific Northwest Laboratory, Richland, Hashington. 
GoTes, R. H., and G. J. Sevigny. 1983b. "Off-Gas Characteristics of Liquid-Fed Joule-Heated Ceramic Melters." Proceedings of the 17th DOE Nuclear Air Cleaning Conference (1982: Denver, Colorado). National Technical Information Service, Springfie7d, Virginia.

Goles, R. H., and C. M. Andersen. 1986. "LFCM Emission and Off-Gas System Performance for Feed Component Cesium." In: Proceedings of the American Nuclear Society International Topical Meeting Haste Management and Decontamination and Decommissioning, September 14-18, 1986. Eds. Dr. J. M. Pope, I. M. Leonard, and E. J. Mayer. Niagara Falls, New York.

Goles, R. H., and R. K. Nakaoka. 1989. Hanford Haste Vitrification Program Pilot-Sca,le Ceramic Melter Test 23. HWVP-89-IVj0010100B, Pacific Northwest Laboratory, Richi and, Washington.

Harris, L. S. "1966. "Fume Scrubbing with the Ejector Venturi System," Chemical Engineering Progress $4(62): 55$.

Hilliard, R. K., J. D. McCormack, and A. K. Postma. 1981. Submerged Gravel Scrubber Demonstration as a Passive Cleaner for Containment Venting and Purging with Sodium Aerosols. HEDL-TME-81-30, Hanford Engineering Development Laboratory, Richland, Hashington.

Institute of Electrical and Eelectronics Engineers, Inc. 1984. IEEE Guide to the Collection and Presentation of Electrical, Electronic, Sensing Component and Mechanical Equipment Reliability Data for Nuclear-Power Generating Stations, IEEE Standard 500-1984, Nuclear Power Committee, IEEE Power Engineering Society.

Kessler, J. L., and C. T. Randall. 1984. "Performance of -a Large-Scale" Melter and Off-Gas System Utilizing Simulated SRP DHPF Haste." In Waste Management '84, ed., R. G. Post, University of Arizona, Tucson, Arizona, pp 279ff.

McCain, J. D., and W. B. Smith. 1974. Lone Star Steel Steam-Hydro Air Cleaning System Evaluation. EPA-650/2-74-028. Prepared for Office of Research and Development U.S. Environmental Protection Agency, Washington, DC.

Nakaoka, R. K. 1985. Hanford Haste Vitrification Program: Pilot-Scale Ceramic Melter Experiment. HWVP-86-V1124A, Pacific Northwest Laboratory, Richland, Hashington.

Ondrejcin, R. S. 1980. Volatile Ruthenium Chemistry: An Answer to RTA 925-S. DPST-80-254, Savannah River Laboratory, Aiken, South Carolina.

Owen, R. K., and A. K. Postma. 1981. "Development of a Passive, SelfCleaning Scrubber for Containment Venting Applications." CONF-801038, Vol. 1. In: Proceedings of the 16th DOE NucTear Air Cleaning Conference. Ed. $M$. W. First. San Diego, California. 
Rockwel1 Hanford Operations (RHO). 1987. "Standards Pertaining to Radioactive Airborne Emissions." In Environmental protection Manual, RHO-MA139 (Part D), Richland, Washington.

Ruecker, C. M., and P. A. Scott. 1987. Parameters Influencing the Aerosol Capture Performance of the Submerged-Bed Scrubber. PNL-6035, Pacific Northwest Laboatory, Richland, Hashington.

Ruecker, C. M. 1987. Evaluation of the Pilot-Scale Ceramic Melter Off-Gas System. HWVP 86-V1122D, Pacific Northwest Laboratory, Richland, Washington.

Scott, P. A., R. W. Goles and R. D. Peters.: 1985. Technology of .Off-Gas Treatment for Liquid-Fed Ceramic Melters. PNL-5446, Pacific Northwest Laboratory, Rich7and, Washington.

Heisenburger, S., W. Grunewald, and H. Koschorke. 1979. "Vitrification of High Level Radioactive in a Continuous Liquid-Fed Ceramic Meiter." Ceramics in Nuclear Haste Management, CONF-790420, T. D. Chikalla and J. E. Mende7,. ed., U.S. Department of Energy.

Hright, G. T. 1983. "Efficient Particulate Scrubber for-Glass Melter OffGas." Mat. Res. Soc. Proc. Vol. 15, Published by Elsevier Science Publishing Co., Inc. 



\section{APPENDIX A}

\section{SIMULANTS AND SUBSTITUTIONS}




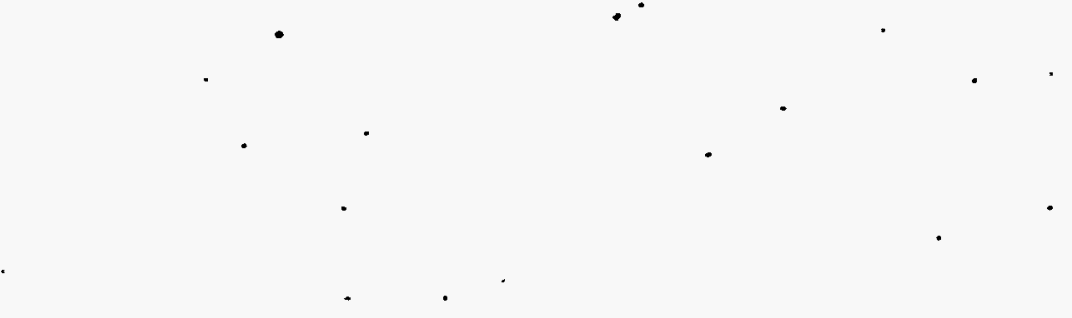

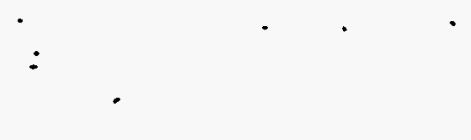

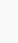




\section{APPENDIX A}

\section{SIMULANTS AND SUBSTITUTIONS}

Equipment performance values are not always available for elements for which emission limits exist; consequent7y the performance parameters derived from chemical analogs were used whenever appropriate. For the actinides, lanthanum and neodymium were used. For the transition.elements, the closest adjacent or group element was utilized. Cadmium, selenium, and tellurium me7ter DFs were obtained from average SRL data while their MOG performances were simulated by PSCM-22 cesium data. Specific substitutions made are listed below:

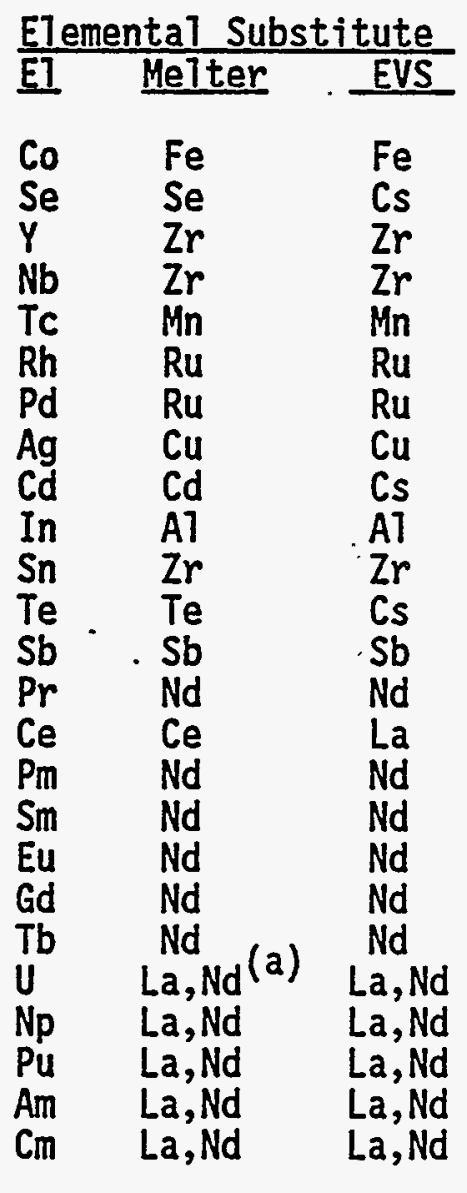

(a) La, Nd signifies averaging the data of these elements.

A.1 


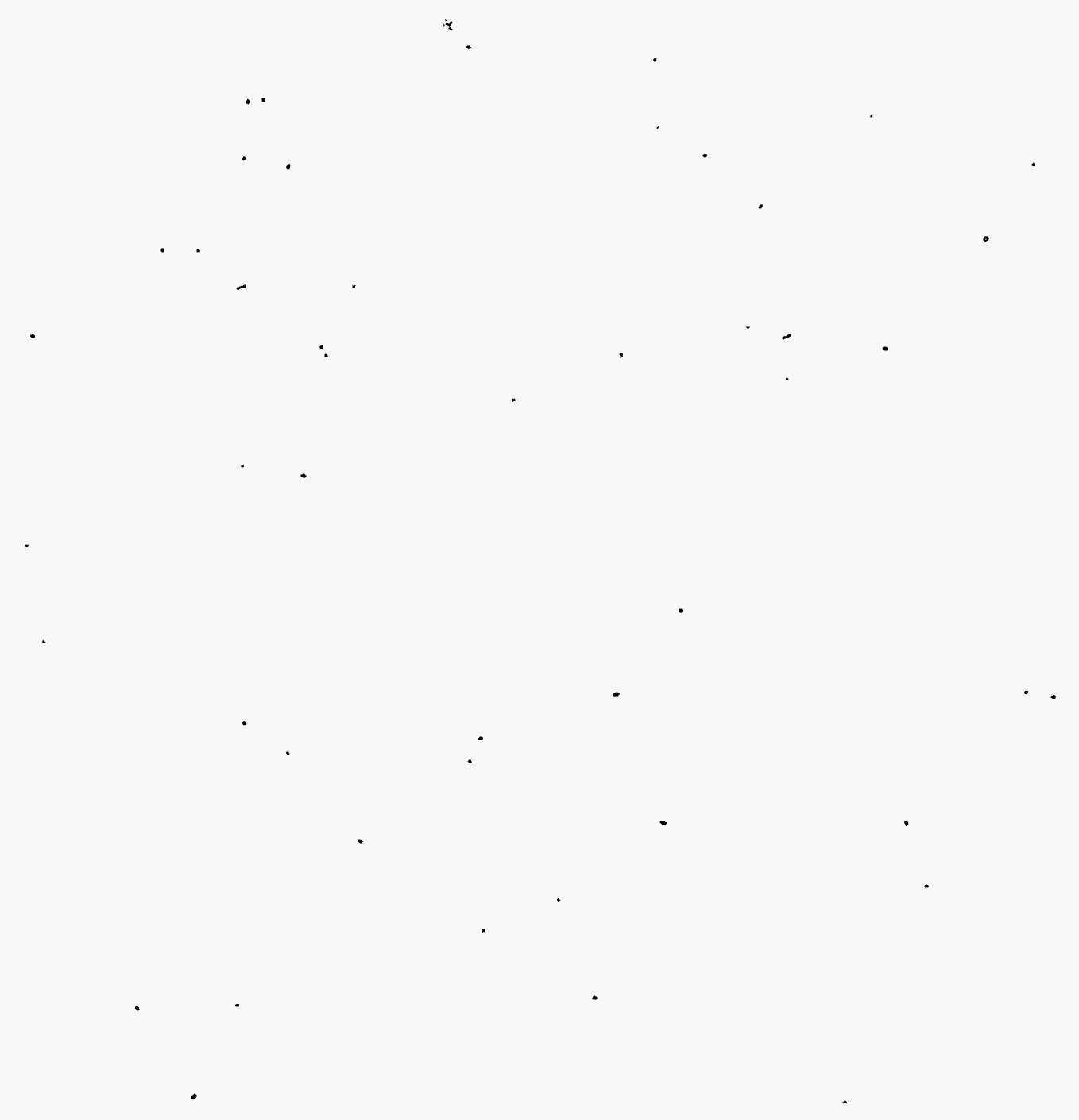




\section{APPENDIX B}

ASSUMPTIONS AND BASES FOR ENERGY ANALYSIS 



\section{ASSUMPTIONS AND BASES FOR ENERGY ANALYSIS}

Because the HWVP Advanced Conceptual Design (ACD) is in a preliminary design phase, and since the ACD off-gas source terms were used for DHPF and HVDP, it was necessary to make assumptions to complete the energy analysis. Whenever possible, documented flow sheet conditions were used, and when information was unavailable or inappropriate, assumptions were made. The major assumptions that were used to complete the mass and energy balances necessary to perform the energy analysis are provided in this appendix.

\section{MELTER AND VESSEL VENTILATION SYSTEM SOURCE TERMS}

The off-gas compositions and flow rates from the HWVP melter and from the. HWVP vessel ventilation system (VVS) have been used as source terms for the off-gas systems at the HWVP, the DWPF and the HVDP. Using HWVP conditions for all three facilities has resulted in a normalized comparison of the energy requirements. That is, the analysis is based upon the energy necessary to process a set quantity of off-gas.

The HWVP meiter off-gas production rate and composition is based upon a glass production rate of $100 \mathrm{lb} / \mathrm{h}$ (HWVP 1988, Section 1 , Item 300 ).. Based on a melter feed composition of $500 \mathrm{~g} / \mathrm{L}$ total oxides and a feed density of $1.33 \mathrm{~kg} / \mathrm{L}$ (HWVP 1988, Section 13 , Item 300 ), the total steam $\left(\mathrm{H}_{2} \mathrm{O}\right)$ in the melter off-gas is approximately $160 \mathrm{lb} / \mathrm{h}$ (01guin 1988, p. 18). The noncondensible vapor flow rate out of the melter used for the energy analysis was $390 \mathrm{lb} / \mathrm{h}$. This flow rate was based upon an air sweep flow rate of $2 \mathrm{scfm}$ per camera, a melter air-inleakage rate of $50 \mathrm{scfm}$, and a back-up film cooler air flow rate of $30 \mathrm{scfm}$ (LaRue 1986).

- Based on the results of PSCM 23 (Goles et a1. 1988, Chap. 10) and PSCM 22 (Nakaoka 1986, p 40), the temperature of the melter off-gas at the inlet to the film cooler $(F C)$ was assumed to be $750^{\circ} \mathrm{F}$ for the energy analysis. During PSCM 23, the average plenum temperature was approximately 
$950^{\circ} \mathrm{F}$, and during $\mathrm{PSCM} 22$, the average was approximately $530 \circ \mathrm{F}$. The average plenum temperature from these two runs was approximately $750^{\circ} \mathrm{F}$.

The pressure of the off-gas from the melter was assumed to be 14.0 psia. At the site elevation of $700 \mathrm{ft}$, the atmospheric pressure is 14.3 psia. The melter cell was assumed to be 1-in. water below atmospheric pressure, and the meiter pressure was assumed to be at a 7-in. water vacuum relative to the cell pressure.

In summary, the melter off-gas flow rate used for the energy analysis for the HWVP, the DWPF and the WVDP was $550 \mathrm{lb} / \mathrm{h}$, of which $160 \mathrm{lb} / \mathrm{h}$ was water vapor. Although other gases will be in the melter off-gas stream (e.g., $\mathrm{CO}_{2}$, $\mathrm{NO}, \mathrm{NO}_{2}, \mathrm{SO}_{2}$ ), their concentrations are not expected to be high enough to significantiy impact the results of the energy analysis. As a result, the off-gas from the melter and vessel ventilation system (VVS) have been treated as an ideal mixture of water and air for energy and mass balance calculations.

The HWVP source for the WV was based upon information given in the Hanford Waste Vitrification Technical Data Package (HWVP 1988, Section 3, Item 700). Normal flow rates are given. in the data package for some of the vessels serviced by the VVS (HWVP 1988, Section 3, Item 700, Table 3-3). Flow rates of $30 \mathrm{scfm}$ have been assigned to those vessels for which a normal flow rate has not been determined. For the energy analysis, the off-gas from the vessels was assumed to be saturated with water vapor at the normal vessel operating temperatures. To determine these operating temperatures, the HWVP reference conceptual design (RCD) was examined. From the RCD, off-gas from a number of vessels (SRAT, SME, SMECT, MFT, SFHT, DWTT, and.RHCT) entered the formic acid vent condenser (FAVC) at 122 •F (F7uor Technology, Inc. 1987, Drawing SK-2-91288). Therefore, $120 \cdot \mathrm{F}$ was assumed to be the operating temperature of these vessels for the HWVP ACD. Other vessels connected to the VVS were assumed to be at $70 \circ \mathrm{F}$. The vessels, flow rates and temperatures that have been used for the energy analysis are provided in Table B.1. 
TABLE B.1. Vesser Vent System Flow Rates and Temperatures Used for Energy Analysis

\begin{tabular}{|c|c|c|c|}
\hline Vessel & Name & $\begin{array}{c}\text { Flow Rate, } \\
\text { scfm }\end{array}$ & $\begin{array}{c}\text { Temperature, } \\
{ }_{{ }^{\circ} \mathrm{F}}\end{array}$ \\
\hline SRAT & $\begin{array}{l}\text { S7udge Receipt Adjustment Tank } \\
\text { (via SRAT Condenser) }\end{array}$ & 30 & 120 \\
\hline SME & STurry Mix Evaporator & 30 & 120 \\
\hline SMECT & SME Condensate Tank (sparger) & 50 & 120 \\
\hline MFT & Melter Feed Tank & 50 & 120 \\
\hline SFHT & Spent Frit Hold Tank (sparger) & 50 & 120 \\
\hline DWTT & $\begin{array}{l}\text { Decon Waste Treatment Tank } \\
\text { (sparger) }\end{array}$ & 30 & 120 \\
\hline RWCT & Recycle Waste Condensate Tank & 30 & 120 \\
\hline PDC & Preliminary Decon Chamber & 30 & 70 \\
\hline FDC 1 & Final Decon Chamber \#1 & 30 & 70 \\
\hline FDC 2 & Final Decon Chamber \#2 & 30 & 70 \\
\hline REDC & Remote Equipment Decon $\mathrm{Cel} 1$ & 30 & 70 \\
\hline CDMC & Contact Decon Maintenance Cel1 & 30 & 70 \\
\hline CDA & Crane Decon Area & 30 & 70 \\
\hline
\end{tabular}

For the HWVP ACD, the off-gas from al1 vessels serviced by the VVS will pass through the VVS SBS. For the DWPF, only the vessels that were connected to the FAVC for the RCD were assumed to be connected to the DWPF FAVC. The remaining vessels at the DWPF were assumed to be connected to the VVS downstream of the FAVC. For the WVDP, it was assumed that the off-gas from all vessels in Table B.1 would pass through the VVS condenser.

\section{MELTER OFF-GAS SYSTEM ASSUMPTIONS}

Heat capacities used to support energy calculations were calculated by assuming that off-gas behaves as an ideal mixture of air and steam.

A11 air-inleakage to off-gas system components was assumed to be at $70^{\circ} \mathrm{F}$ and at $70 \%$ relative humidity. Air injected into the off-gas stream in the off-gas $\mathrm{FC}$ and the pressure control air were also assumed to be at $70^{\circ} \mathrm{F}$ and $70 \%$ relative humidity. 
For the energy analysis calculations it has been assumed that the mean temperature difference between the cooling water and the water accumulated in the SBSs and the OGCT was $15 \circ \mathrm{F}$.

\section{Film Cooler and Pressure Control Air}

Based on an EDT (EDT-4000092), an air. flow rate of $700 \mathrm{lb} / \mathrm{h}$ to the offgas $F C$ was used for the energy analysis. The pressure control air flow rate has also been assumed to be $700 \mathrm{lb} / \mathrm{h}$. [The pressure control air flow rate for the HWVP RCD was approximately $600 \mathrm{lb} / \mathrm{h}$ (F7uor Technology Inc. 1987, Drawing SK-2-91285)]. It was àssumed that the pressure drops through the FC and at the injection point of the pressure control air were negligible.

\section{Submerge Bed Scrubbers}

A pressure drop of 36-in. water was assigned to the off-gas flowing through the SBS for the HWVP and the WVDP (Goles et al. 1988, Section 10.2.3; Siemens et a1. 1986, Section 4.2.1.3; O1guin 1988, p 37). For the energy analysis, it was assumed that the air-inleakage rate to the SBSS was $30 \mathrm{scfm}$.

Based on the average of four references, the temperature of the off-gas from the SBS was assumed to be $95 \circ F$ (Goles et al. 1988, Section 10.2.4; Siemens et a7. 1986, Section 4.2.1.6; 01guin 1988, p. 40; Larson et al. 1988, Section 3.4.2). It was further assumed that the SBS liquid temperature was in equilibrium with the off-gas temperature $\left(95^{\circ} \mathrm{F}\right)$.

Ejector Venturi Quencher and Steam-Atomized Scrubbers

The liquid in the OGCT at the DWPF was assumed to be maintained at the same temperature $\left(95^{\circ} F\right)$ as the liquid in the SBSs at the WVDP and the HWVP. Therefore, the temperature of the quench water to the venturi quencher used for the energy analysis was also $95^{\circ} \mathrm{F}$. For the HWVP RCD (which included a venturi quencher and an SAS in the melter off-gas system), the temperature of the quench water increased approximately $5^{\circ} \mathrm{F}$ during the quenching process, and the temperature of the cooled off-gas and the heated quench water were equal (Fluor Technology Inc. 1987, Drawing SK-2-91285). Therefore, it has been assumed that the temperature of the off-gas and water exiting the quencher at the DWPF will be $100^{\circ} \mathrm{F}$. 
To quench the off-gas to $100^{\circ} \mathrm{F}, 80 \mathrm{gpm}$ water will be required. It has been assumed that quench water will be supplied from the OGCT with a vertical enclosed impeller pump at approximately 40 psig (Ametek 1981). Vender literature (Lawrence Pump and Engine) was used to estimate the power that wi11 be required to operate this pump.

The off-gas from the DWPF melter will be scrubbed by two steam atomized scrubbers (SASs), operated in series. For the single SAS included on the HWVP RCD, steam and water were used at the rates of 0.2-7b steam and 4.5-1b water per pound dry off-gas (F7uor Technology Inc. 1987, Drawings SK-2-90725, SK-2-91285 and SK-2-91286). For the DHPF energy analysis, the RCD rates of steam and water addition were used for each of the DWPF SASs (i.e., for each pound of dry off-gas, 0:4-1b steam and 9-7b water will be used).

From the HWVP RCD (F7uor Technology Inc. 1987, Drawing SK-2-91286), the steam used in the SAS was at 165 psia. Therefore, it was assumed that the steam supplied. to the DWPF SASs was saturated at 165 psia. As with the venturi quencher, it was assumed that the water to the SASs will be supplied at 40 psig. The power to the water pump was also determined with the use of vendor information (Lawrence Pump and Engine).

Off-Gas Condensate Tank

The OGCT at DHPF will receive liquid effluent from the venturi ejector, the SASs, the condenser, and the HEME. For the energy analysis, it was assumed that the temperature of the liquid would be maintained at $95^{\circ} \mathrm{F}$. It was also assumed that the air-inleakage rate to the OGCT would be $50 \mathrm{scfm}$. Off-Gas Condenser

At the DWPF, the off-gas that exits from the SASs wi11 be saturated with water vapor at approximately $130^{\circ} \mathrm{F}$. Most of this water vapor is removed from the off-gas when it is cooled to $95^{\circ} \mathrm{F}$ in the condenser. The pressure drop. across the condenser was assumed to be 10-in. water.

High-Efficiency Mist Eliminators

For the HEMEs in all three off-gas systems, it has been assumed that the air-inleakage rates will be approximately 30 scfm. Based on the PSCM 23 run, 
the pressure drop across the HEME for the energy analysis was assumed to be 3-in. water (Goles et al. 1988, Sec. 10.2.5).

\section{HEPA Preheaters}

To ensure that the off-gas passing through the HEPA fi7ters does not condense, it first passes through electrical resistance heaters. For the HWVP, the heater must raise the temperature of the off-gas so that its relative humidity is less than $85 \%$ (HWVP 1988, Section 3 ; Item 600 ). Assum-

.. ing that the off-gas exiting the HEME is saturated with water at $95^{\circ} \mathrm{F}$, raising the temperature $18^{\circ} \mathrm{F}$. $\left(10^{\circ} \mathrm{C}\right)$ will lower the off-gas humidity to approximately $60 \%$. Therefore, $18 \cdot \mathrm{F}$ has been used as the heater temperature rise for the energy analysis. It has also been assumed that there is no airinleakage and that a 1-in. water pressure drop is incurred as the off-gas passes through the heater.

\section{High-Efficiency Particulate Air Filters}

Based on PSCM 23 (Goles et a7. 1988, Section 10.2.6) and vender information (Mine Safety Appliance Company), a pressure drop of 2-in. water was assigned to each HEPA filter. It was assumed that all three melter off-gas systems use two HEPA filters in series before the off-gas is exhausted through blowers.

\section{Off-Gas Blowers}

It has been assumed that all melter off-gas and VVS blowers for the three facilities will be rotary positive blowers driven by variable speed. motors. From the HWVP RCD (F7uor Technology Inc. 1987, Drawing SK-2-90725), the melter off-gas blower was to be designed to exhaust 1200 ACFM at a pressure differential of 4.1 psi. The actual flow rate (Fluor Technology Inc. 1987, Drawing SK-2-91286) to the blower for the RCD was approximately 800 ACFM with a blower pressure differential of 4 psia. Therefore, for the energy analysis it was assumed that all blowers would be designed to handle twice their normal flow rates. Consequentiy, the blowers would normaliy operate at 50\% of their rated capacity. At 50\% capacity, the efficiency of utilized motor power is approximately 80\% (McGraw-Hil1 1976, Section A5.1.1, Table A5.1). For example, if $10 \mathrm{hp}$ is required at the shaft of a motor rated at $20 \mathrm{hp}, 12.5 \mathrm{hp}(10 \div 0.8)$ will be the power consumed by the motor. 
To calculate the energy required by blowers, vender information (Dresser Industries Inc.) was used to estimate the horsepower. This value was then divided by 0.8 to account for the decrease in efficiency as a result of oversizing the blower motor.

The vacuum that must be maintained at the blower inlet is a sum of the pressure drops through the off-gas system components, and the pressure difference between the melter and the melter cell. For the analysis, it has been assumed that the melter ce!1 and the exhaust tunnel are approximately at the same pressure. The pressure drop associated with the off-gas flow through the jumpers (interconnecting piping) has been estimated at 4-in. water for the HWVP. This estimate was based on $120 \mathrm{ft}$ of 6-in. dia piping and a fitting factor of 6 (McCabe, Smith 1976). Consequently, an additional 4-in. water pressure drop was included for all blower power calculations.

\section{VESSEL VENTILATION SYSTEM ASSUMPTIONS}

The HWVP vesse 7 ventilation system consists of an SBS, a heater, two HEPA filters and a blower. The assumptions for these components (temperatures, air-inleakage rates, and pressure drops) are identical to those discussed under melter off-gas systems. The off-gas inlet pressure to the SBS was assumed to be 14.1 psia. This assumption is based on the site pressure of 14.3 psia, a 1-in. water vacuum in the vessels, and a 5-in. water pressure drop across the vesse 1 condensers. A 4 in. water pressure drop was included with in the VWS blower power calculation to account for the pressure drop associated with the system piping.

The VVS at the DWPF consists of a condenser (FAVC), a heater, a filter and a blower. As with the HWVP, the pressure at the inlet to the FAVC was assumed to be at 14.1 psia. A HEME is contained within the FAVC; therefore, the pressure drop across the FAVC was assumed to be 12-in. water. The filter specified for the DWPF VVS appears to have been designed to satisfy sitespecific conditions. To provide for a normalized energy analysis, the filter was replaced with two HEPA filters. As with the melter off-gas systems, a 4in. water pressure drop was attributed to the VVS interconnecting piping. 
The WV at the WVDP consists of a single.condenser. Following the condenser, the WV is tied into the melter off-gas system. The off-gas from the VVS and melter off-gas mix before entering the MOG system HEME. The outlet temperature from the WV condenser was assumed to be $95 \circ \mathrm{F}$.

\section{LIQUID EFFLUENT PROCESSING}

Steam generated in the melter or injected into the off-gas system. will be contaminated to some extent with radioactive and chemical constituents. Consequent7y, condensed steam that accumulates within the off-gas systems must be treated and processed before it can be discarded. Decontamination solution must also undergo some processing; however, the annual quantities of decontamination solution generated are insignificant when compared to process effluent annual quantities (Table 19).

For the HWWP, it has been assumed that liquid effluent that accumulates in the SBS will be transferred in batches to the DWTT. The liquid effluent will enter the DWTT at $95 \circ F$, and then will be heated and evaporated. (For the energy analysis it has been assumed the 100\% of the SBS liquid effluent will be evaporated.) The vapor will be condensed and cooled to $125 \circ$. Next, the condensate will be transferred to the 242-A evaporator where $90 \%$ of it will be evaporated again. This relatively clean vapor will be condensed and cooled to $125 \% \mathrm{~F}$ before it is discarded. The remaining $10 \%$ of the liquid effluent in the 242-A evaporator will be cooled to $125^{\circ} \mathrm{F}$, and eventualiy used as grout make-up water.

For the energy anaiysis, it was assumed that 100 psia process steam would be utilized to facilitate the required evaporations. Assuming that the evaporation are $90 \%$ efficient and 100\% of the steam condenses and leaves the heating coils as water at $150 \circ, 2.1-16$ steam will be required to process each pound of liquid effluent. It was also assumed that the process cooling water would be available at $80^{\circ} \mathrm{F}$ to $\mathrm{cool}$ and condense the vaporized effluent. If it is assumed that cooling water exits from the condensers at $125^{\circ} \mathrm{F}$, then $5.4 \mathrm{gal}$ of cooling water will be required for each pound of liquid effluent.

It has been assumed that al1 three facilities will utilize similar processes for effluent treatment. Therefore, the rates of steam and cooling 
water to process liquid effluent (given above) have been used to calculate the energy requirements for liquid waste treatment for the three off-gas systems.

\section{COST ASSUMPTIONS}

Utility cost data were used to estimate the operational energy costs of the off-gas systems. Motors (for pumps and blowers) and heaters were assumed to be powered by electricity. It was assumed the process cooling water (not chilled) would be used for all cooling operations. The utility costs, in 1988 dollars, are provided in Table B.2.

- The RCD glass production rate was based on a plant operational avai7ability of $70 \%$ (Hestinghouse Hanford Company 1987, p. 2). Therefore, annual operating costs of the off-gas systems are based on $6100 \mathrm{~h}$ of operating time per year $(24 \times 365 \times 0.7)$.

TABLE B.2. Utility Costs

$\begin{array}{ll}\frac{\text { Utility }}{\text { Electricity }} \cdot & \frac{1}{\text { Unit Price }} \\ \text { Steam } & \$ 0.0294 / \mathrm{kWh}(\mathrm{a}) \\ \text { Cooling Water } & \$ 0.12 / 1000 \mathrm{gal}(\mathrm{b})\end{array}$

(a) Hestinghouse Hanford Company, Appendix $F$, pp. F.2-F3.

(b) Using the Chemical Engineering Cost Index, the cooling water cost from 1969 (Perry, Chilton 1973, Section 25, Table 25-30) was transposed to August 1988 do11ars. 


\section{B.6 - REFERENCES}

Ametek Bulletin SM981H, Ametek, Schutte and Koerting Division, Cornwe11 Heights, Pennsyivania (1981).

Dresser Industries Inc., Bulletin B-5125 Roots Universal RAI BTowers, 2929706, Connersvilie, Indiana.

EDT-400092. Melter Off Gas System Film Cooler Technical Information.

Fluor Technology Inc. 1987. Reference Conceptual Design, "HWVP Technical Description and Drawing; Book 3, SD-HHV-TI-007, Rev. 0, Fluor Technology Inc., April 1987.

Goles, R. W. et al. 1988. "HWVP Pilot-Scale Ceramic Melter Test 23," HWVP-89-1VJ0010100B, January 1989.

HWVP. 1988. "Hanford Waste Vitrification PTant Technical Data Package." SD-HWV-DP-001, Rev. 4, Oct. 4, 1988.

Larson, D. E. et al. 1988. "WVDP Vitrification Process Description, " Draft, Apri1 1988.

LaRue, K. M. 1986. HWVP Transmittal RFT-049, K. M. LaRue to R. N. Gibbons, "Technical Infortiation Required Report No. 1," dated June 10, 1986.

Lawrence Pump and Engine, Bulletin 829-1, Lawrence, Maine.

McCabe, H. L. and J. C. Smith. 1976. "Unit Operations of Chemical Engineering, " 3 ed, McGraw-Hi71, New York (1976).

ṀCGraw-Hi17. 1976. Institut Francais Du Petrole, "Manual of Economic Analysis of Chemical Processes, McGraw-Hill Book Company, New York (1976).

Mine Safety Appliance Company, Bulletin No. 1500-11, Nuclear Filtration Systems Catalog, Evans City, Pennsylvania.

Nakaoka R. K. 1986. "HHVP Pilot-Scale Ceramic Melter Experiment, HWVP-12/PSCM-22, HWVP-86-V1124A, December 1986.

01guin, L. 1988. "HWVP Melter Off Gas System Heat and Material Balance Calculations," Rev. B, August 1988.

Perry, R. H. and C. H. Chilton. Chemical Engineers Handbook, 5th ed., McGraw-Hi17, New York (1973).

Siemens, D. H. et a7. 1986. "Design and Operating Features of the HighLevel Waste Vitrification System for the West Valley Demonstration Project," PNL-5780, March 1986.

Hestinghouse Hanford Company. 1987. HWVP Reference Conceptual Design Report, HHE-EP-0044, Richland, Washington (July. 1987). 
